\title{
ENHANCED STABILISATION OF MUNICIPAL SOLID WASTE IN BIOREACTOR LANDFILLS
}


Promoter: $\quad$ Prof. dr. H.J. Gijzen,

Professor of Environmental Biotechnology

UNESCO-IHE Institute for Water Education

The Netherlands

Co-promoter: $\quad$ Dr. H.J. Lubberding.

Senior lecturer Microbiology

UNESCO-IHE Institute for Water Education

The Netherlands

Awarding Committee: Prof. dr. ir. P.N.L. Lens

UNESCO-IHE Institute for Water Education

The Netherlands

Prof. dr. A. Haarstrick

Technische Universität Carolo-Wilhelmina zu

Braunschweig

Germany

Prof. dr. ir. W.H. Rulkens

Wageningen University

The Netherlands

Dr. ir. G.A.M. van Meurs

Deltares (formally called GeoDelft)

The Netherlands 


\title{
ENHANCED STABILISATION OF MUNICIPAL SOLID WASTE IN BIOREACTOR LANDFILLS
}

\author{
DISSERTATION \\ Submitted in fulfilment of the requirements of \\ the Academic Board of Wageningen University and \\ the Academic Board of the UNESCO-IHE Institute for Water Education \\ for the Degree of DOCTOR \\ to be defended in public \\ on Thursday, $3^{\text {rd }}$ of July 2008 at 15:30 hrs \\ in Delft, The Netherlands
}

by

Roberto Valencia Vázquez born in Durango, México 
CRC Press/Balkema is an imprint of the Taylor \& Francis Group, an informa business

(C) 2008, Roberto Valencia Vázquez

All rights reserved. No part of this publication or the information contained herein may be reproduced, stored in a retrieval system, or transmitted in any form or by any means, electronic, mechanical, by photocopying, recording or otherwise, without written prior permission from the publishers.

Although all care is taken to ensure integrity and the quality of this publication and the information herein, no responsibility is assumed by the publishers nor the author for any damage to the property or persons as a result of operation or use of this publication and/or the information contained herein.

Published by:

CRC Press/Balkema

PO Box 447, 2300 AK Leiden, The Netherlands

e-mail: Pub.NL@taylorandfrancis.com

$\underline{\text { www.crcpress.com }}$ - www.taylorandfrancis.co.uk $-\underline{\text { www.balkema.nl }}$

ISBN 978-0-415-47831-1 (Taylor \& Francis Group)

ISBN 978-90-8504-918-0 (Wageningen University) 
To Bere and Sarah 



\section{Summary}

The increasing development and urbanization of the society has led to an increase per-capita production of municipal solid waste (MSW) materials. These MSW materials are of organic and inorganic nature that can be of rapidly, moderately and slowly biodegradable or inert characteristics. With regard to these waste streams a wide variety of treatments exist: reuse and recycling, composting, anaerobic digestion, incineration, and land disposal are the most common ones, pyrolysis and gasification are in use to a lesser extent or on a smaller scale. Regardless of the method chosen for treatment all these methods produce residues, which will be eventually disposed at open dumps or sanitary landfills. Sanitary landfills are engineered facilities that make use of barriers to isolate the waste from the biosphere in order to protect human health and the environment. However, these barriers will fail in the long-term allowing the intrusion of moisture into the waste mass, which will trigger restrained physical, chemical and biological processes causing pollution in the form of leachate and landfill gas.

In order to minimise the negative impacts of landfilling of waste, researchers conducted experiments, which resulted today in the so-called bioreactor landfill approach. The bioreactor landfill is a system that is operationally influenced to promote synergy between the inherent microbial consortia, and is controlled to accelerate the sequential phases of waste stabilisation through the addition of liquids and/or air. These past investigations have allowed the determination of optimal ranges for the key process parameters and the implementation of alternative operational conditions, the so-called enhancement techniques. Two main perspectives can be identified: 1) the American perspective, which attempts to apply enhancement techniques in order to maximise landfill gas production; 2) the European perspective that focus on the achievement of the Final Storage Quality (FSQ) status of residues within a generation timeframe (30 years). The term FSQ suggests that the potential of a waste material to produce pollution is reduced to nearly zero in the long-term perspective, similar to the characteristics for inert waste laid in the Waste Acceptance Criteria (WAC) of the European Landfill Directive. Until now, the main technical problem faced by landfill operators is homogenous liquid addition and distribution (key enhancement technique) within the waste mass. The main 
objective of this thesis was to achieve a FSQ status of waste, through laboratory and pilot-scale experiments, that complies with the WAC of the Landfill Directive for Inert waste, which had been considered as the worstcase scenario due to the stringent criteria established. Therefore, this thesis focused on the interaction and modification of the factors controlling the waste stabilisation process in order to have a better understanding of the physical, chemical and biological processes occurring in a bioreactor landfill.

Bench (1 L), laboratory (50 L) and pilot-scale (800 L) simulators were used to apply different combinations of enhancement techniques (shredding. buffer addition, septage addition, and forced air intrusion) in order to achieve FSQ of residues. In addition, coarse materials (as layers or homogenous mixtures) were used in order to improve the hydraulic conditions of the simulators. The results of these experiments revealed that it was possible to achieve biological stabilisation within 1 year, but not FSQ status. Achievement of FSQ status depends strongly on the initial solid waste composition. Nevertheless, the residues were close to comply with the WAC of the Landfill Directive for inert waste. Buffer and septage addition proved to have a positive impact on the waste stabilisation process, reducing the biogas production lag-phase. Additionally, the risks associated with septage disposal were practically eliminated as no faecal coliforms were detected after 1 year of operation. Also the use of coarse materials had a positive impact on the waste stabilisation process, especially as homogenous mixtures and layers to a lesser extent since they were prone to clogging.

Nitrogen compounds, especially ammonium, have been identified as a main parameter that will jeopardise the achievement of FSQ status, hence the safe closure of landfill sites. Therefore, evolution and fate of nitrogen compounds were also investigated in this thesis. The experiments showed that about $40 \%$ of the total ammonium was released by physical processes within 24 hours; the other $60 \%$ was produced by biological degradation of proteins contained in the MSW. Anammox bacteria were found for the first time in bioreactor landfills and it was suspected to have an important contribution to the total removal of nitrogen from the system, beside other nitrogen removal processes. Nevertheless, it was not clear how or where the 
intermediate products (i.e. nitrite) necessary for Anammox metabolism were produced.

The Landfill Degradation and Transport (LDAT) model was used to simulate the evolution of carbon and nitrogen compounds. The LDAT model was not suitable to represent accurately the processes occurring in the simulators mainly because the model operated at a fixed $\left(20^{\circ} \mathrm{C}\right)$ process temperature and the waste chemistry equations need to be improved. Other models found in literature could be more appropriate to describe these processes; however, it was noticed that these models lack a complete ionic balance which has great influence on the $\mathrm{pH}$ of the system. The experimental research emphasised the importance of increasing $\mathrm{pH}$ values to neutral $\mathrm{pH}$ values, which "triggered" most of the processes in the simulators. This thesis highlighted the need to focus future modelling efforts on the integration of this complete ionic balance and its influence on the development of neutral (even alkaline) $\mathrm{pH}$ levels.

In conclusion, this research reduced our current gaps-in-knowledge and offered feasible technical alternatives to control and steer the processes occurring in a bioreactor landfill aiming to achieve FSQ status of residues. 



\section{Acknowledgements}

During these years many people got involved in one way or another in my research project and for your contributions you will always have my sincere gratitude. However, I feel obliged to acknowledge the special contributions of some of these persons that allow me to complete this research.

First and foremost, I would like to thank my promotor Prof. dr. H. (Huub) J. Gijzen who took me under his wing and introduced me to the bioreactor landfill idea, but also because you always stood behind me when I needed you. Thank you very much Huub. Secondly, I am very grateful to my copromotor Dr. H. (Henk) J. Lubberding, not only for taking the risk of being my mentor and for providing excellent guidance and criticisms but for your sincere friendship. Henk, it was not only delightful but an honour and a privilege to have worked with you all these years. I shall not forget to mention Willem van der Zon (GeoDelft), who not only provided all the necessary funds and materials to conduct and complete this research, but defended the existence of the pilot-scale experiments. Willem: "saint Willem", despite the fact that not everyone understood or appreciated your peculiar sense of humour, you were a great support to me not only professionally but also on a personal level, thank you very much.

I would like to acknowledge the financial support of the National Council of Science and Technology of Mexico (CONACyT), as well as the financial support given by Mr. Frans Föllings and Mr. Michiel Kuijpers of ESSENT Milieu to complete this research. I give particular thanks to Hans Woelders of ESSENT Milieu Wijster for introducing the ammonium problem but also for providing the five tons of solid waste to conduct these experiments.

I would like to thank all the staff of the Environmental Resource department because you make me feel like one of you: a colleague, especially to Vera Schouten for the cheering smile in the mornings and always looking after me. A sincere word of appreciation to the Students Affairs department for helping me out all these years, but in particular to Jolanda Boots for her creativeness sorting out all kind of problems. All my gratitude to the UNESCO-IHE laboratory staff for all the support and assistance, thank you Fred, Frank, Don, Lyzette and Peter, but also thank you Cees Bik (2005†) 
who taught me that the simpler the better. Cees, I still have and use your snoopy bookmark. I am indebted to the personnel of GeoDelft, especially to Rob Man in't Veld and Paul Schaminée for providing me with all necessary tools and full-access codes to GeoDelft facilities to conduct the pilot-scale experiments. I shall not forget to mention Mr. A. van der Berg (biologisch melkbedrijf) who was always happy after I emptied his family septic tank, even after I destroyed his garden several times. I am very thankful to those who worked with me (Elpido, Mohan, Francis, Josephine, Rose Marie, Diane, Jeroen and Arno), not only for your invaluable input to this thesis but for teaching me important lessons about human behaviour and ingenuity. Dear Dr. T. (Timmo) Heimovaraa, thank you for investing so much of your personal time helping me with my modelling chapter, I owe you one.

To the people that I can consider my closest friends: thank you Carmen and Carlos -the ideal $\mathrm{PhD}$ researchers- for sharing your time with us and helping us to take care of Sarah. Thanks to another couple: Diana and Gianluca for your sincere and honest friendship. I also would like to thank my friends in the Institute for your camaraderie: Wendy Sturrock for helping me out with my English problems and infinite reunions at your home with Frank; Dr. Klaas Schwartz with whom I not only shared the football glory but also a couple of beers and Edwin Hess with whom I share a lot of laughs and nice ironic comments about life and football. I am thankful to my parents for giving me the proper education to achieve this important step in my professional career. I will never forget all the support given by Dr. H. (Hiram) Medrano who send me originally to do a MSc (1999) and later to pursuit a $\mathrm{PhD}$ (2003), despite the fact that I "stole" and married his daughter in between; also thank you Mrs Gloria Trujillo for your continuous moral and spiritual support all these years. A special mention goes to Yima Medrano for "fixing" the picture of the thesis cover at the last minute, thank you compadre.

Last but not least to my beloved wife, Bere. Thank you for all your support, understanding and courage to stand next to me all these years. Solo tú sabes cuanto pasamos para llegar el día de hoy aquí, gracias de todo corazón mi pequeña chaparrita 


\section{Contents}

Summary VII

Acknowledgments $\quad$ XI

1 Introduction 1

1 Background 1

2 Factors controlling waste stabilization 6

3 Enhancement techniques for enhanced waste stabilization 7

3.1 Strategies for liquid recirculation 9

4 The final storage quality (FSQ) of waste residues 11

5 Motivation and scope of the thesis 14

6 Objectives of the thesis 15

7 Outline of the thesis 15

2 Achieving "Final Storage Quality" of MSW in pilot 25 scale bioreactor landfills

1 Introduction 26

2 Materials and methods $\quad 27$

2.1 Bioreactor landfill simulators setup and operation $\quad 27$

2.2 Analytical procedures $\quad 29$

3 Results $\quad 30$

3.1 Reactor behaviour $\quad 30$

3.1.1 Physical-chemical parameters 30

3.1.2 Biological parameters 31

3.2 Degree of waste stabilisation 33

4 Discussion 34

4.1 Reactor behaviour $\quad 34$

4.2 Carbon and nitrogen mass balances $\quad 37$

4.3 Final storage quality (FSQ) 40 
3 Alternative treatment for septic tank sludge:

Co-disposal with MSW in bioreactor landfill simulators

1 Introduction 46

2 Materials and methods 48

2.1 Bioreactor landfill simulators setup and operation $\quad 48$

2.2 Analytical procedures $\quad 49$

3 Results $\quad 50$

3.1 Behaviour of the reactors 50

3.1.1 Physico-chemical parameters 50

3.1.2 Biological parameters 51

3.2 Degree of waste stabilization $\quad 54$

3.3 Pathogen reduction from the residues of the 55 simulators

4 Discussion 56

4.1 Reactor performance $\quad 56$

4.2 Pathogen removal from residues $\quad 58$

4 The effect of hydraulic conditions on waste 63

stabilisation in bioreactor landfill simulators

1 Introduction 64

2 Materials and methods 65

2.1 Bioreactor landfill simulators setup and operation $\quad 65$

2.2 Analytical procedures $\quad 66$

2.3 Statistical analyses $\quad 67$

3 Results 67

3.1 Process parameters $\quad 67$

3.2 Biological parameters $\quad 68$

3.3 Degree of waste stabilization $\quad 72$

4 Discussion 72

$\begin{array}{ll}\text { 4.1 Process parameters } & 72\end{array}$

4.2 Biological parameters $\quad 73$

4.3 Carbon and nitrogen mass balance $\quad 77$

4.4 The effect of hydraulic conditions $\quad 81$

5 Ammonium release and Anammox as an option for its 87 removal in bioreactor landfill simulators

1 Introduction $\quad 88$

2 Materials and methods $\quad 89$

2.1 Experimental set-ups $\quad 89$

2.2 Analytical procedures $\quad 90$

2.3 Statistical analyses $\quad 91$

3 Results 91

3.1 Bioreactor landfill simulators performance 91

3.2 Ammonium in the bioreactor landfill simulators $\quad 92$

4 Discussion 95 
6 Mathematical simulation of carbon and nitrogen 105 transformations in bioreactor landfill simulators

1 Introduction 106

2 Materials and methods 107

2.1 Experimental set-up and data 107

2.2 LDAT model construction $\quad 108$

3 Results and discussion 109

3.1 LDAT sensitivity analysis $\quad 109$

3.2 LDAT biogas production $\quad 110$

3.3 LDAT $\mathrm{pH} \quad 111$

4 Concluding remarks $\quad 115$

7 Conclusions and outlook 121

1 The past: what we did not know 121

2 The present: what we know now 122

2.1 Physical dynamics $\quad 123$

2.2 Chemical dynamics 124

2.3 Biological dynamics $\quad 124$

2.4 Mathematical modelling 125

3 The future: what do we still need to know further 125

$\begin{array}{lr}\text { Annex } 1 & 129\end{array}$

$\begin{array}{ll}\text { Samenvatting } & 137\end{array}$

$\begin{array}{ll}\text { Curriculum Vitae } & 141\end{array}$ 



\section{1 \\ Chapter}

\section{Introduction}

The journey has begun...

For every action towards graduation, there will be an equal and opposite distraction ...therefore challenge and conquer yourself, only then you will prevail

Newton's $3^{\text {rd }}$ law of graduation and Roberto Valencia

\section{Background}

The increasing human population, urbanisation and wealth fare is leading to an increased per capita production of solid waste materials. During the last 10 years municipal solid waste generation has increased about $20 \%$, of which a majority consists of household and commercial waste and it is expected to increase up to $40 \%$ by the year 2020 as shown in Figure 1 (OECD, 2007). The constituents of household and commercial waste materials are organic and inorganic in nature, and may be of rapidly, moderately, slowly biodegradable characteristics or inert (Table 1) (Tchobanoglous and Kreith, 2002). With regard to these waste streams a wide variety of treatments exist: reuse and recycling, composting, anaerobic digestion, incineration, and land disposal are the most common ones (Williams, 1998) (Figure 2), pyrolysis and gasification are in use to a lesser extent or on a smaller scale (Nolan, 2002). Regardless of the method chosen for treatment all these methods produce residues, which will be eventually disposed at open dumps or sanitary landfills (Westlake, 1995; Williams, 1998). Approximately 1 billion tonnes of municipal solid waste were collected worldwide in 2006 of which only $53 \%$ was finally disposed in landfills (UN, 2007). 
Table 1. Municipal solid waste composition for different income levels.

Waste component

Countries income

High

Medium

Low

\section{Organic}

Food waste

Paper and cardboard

Plastics

6-30

20-65

40-85

Textiles

$20-45$

8-30

$1-10$

2-8

2-6

$1-5$

Rubber and leather

2-6

2-10

$1-5$

Wood and yard waste

$0-2$

$1-4$

$1-5$

Miscellaneous organics

$10-20$

$1-10$

$1-5$

$<1$

$<1$

$<1$

\section{Inorganic}

Glass

4-12

$1-10$

$1-10$

Tin cans

2-8

$1-5$

1-5

Aluminium

$0-1$

$1-5$

$1-3$

Other metals

1-4

$1-5$

$1-5$

Dirt, ash, etc.

0-10

$1-30$

$1-40$

Source: Tchobanoglous and Kreith (2003). Units are in percentage.

Sanitary landfills are engineered disposal facilities, which make use of physical barriers designed to isolate solid waste from the biosphere in order to minimise public health and environmental impacts (Allen, 2001; Tchobanoglous and Kreith, 2002). These barriers (landfill bottom liners and caps) prevent the entry of water, into the waste bulk, which is essential for the degradation process of waste (Westlake, 1995; Allen, 2001). Consequently, the waste is contained and it remains practically intact for long periods of time. Nevertheless, water will always be present within the landfill due to the inherent water content of waste (Westlake, 1995; Allen, 2001). This water, together with previously infiltrated water (e.g. rainfall percolating during the filling process of the landfill), percolates and interacts with the waste and air trapped within the solid matrix, providing favourable conditions for microorganisms development. By their metabolic activities, microorganisms degrade waste until their nutrient sources are depleted and the residues are no longer capable of supporting microbial growth. This process is known as the biological degradation process of organic matter (Buswell and Mueller, 1952; Parkin and Owen, 1986; Zehnder 1988; Palmisano and Barlaz, 1996). This multi-sequential phase process produces gases and releases contaminant substances into the water that percolates through the landfill, resulting in a liquid called leachate. The duration of 
these phases may vary depending on several factors (e.g. climatic and environmental conditions, waste characteristics, operational factors, etc.) and may last from decades to centuries (Wall and Zeiss, 1995; Townsend et al, 1996; Johannessen, 1999; Tchobanoglous and Kreith, 2002). Leachate and landfill gases contain substances that are harmful to human health and the environment (El-Fadel et al, 2002). The leachate escaping from landfills can contaminate soils, aquifers, and surface waters; landfill gas contains greenhouse gases that contribute to the global warming effect when they are released into the atmosphere.

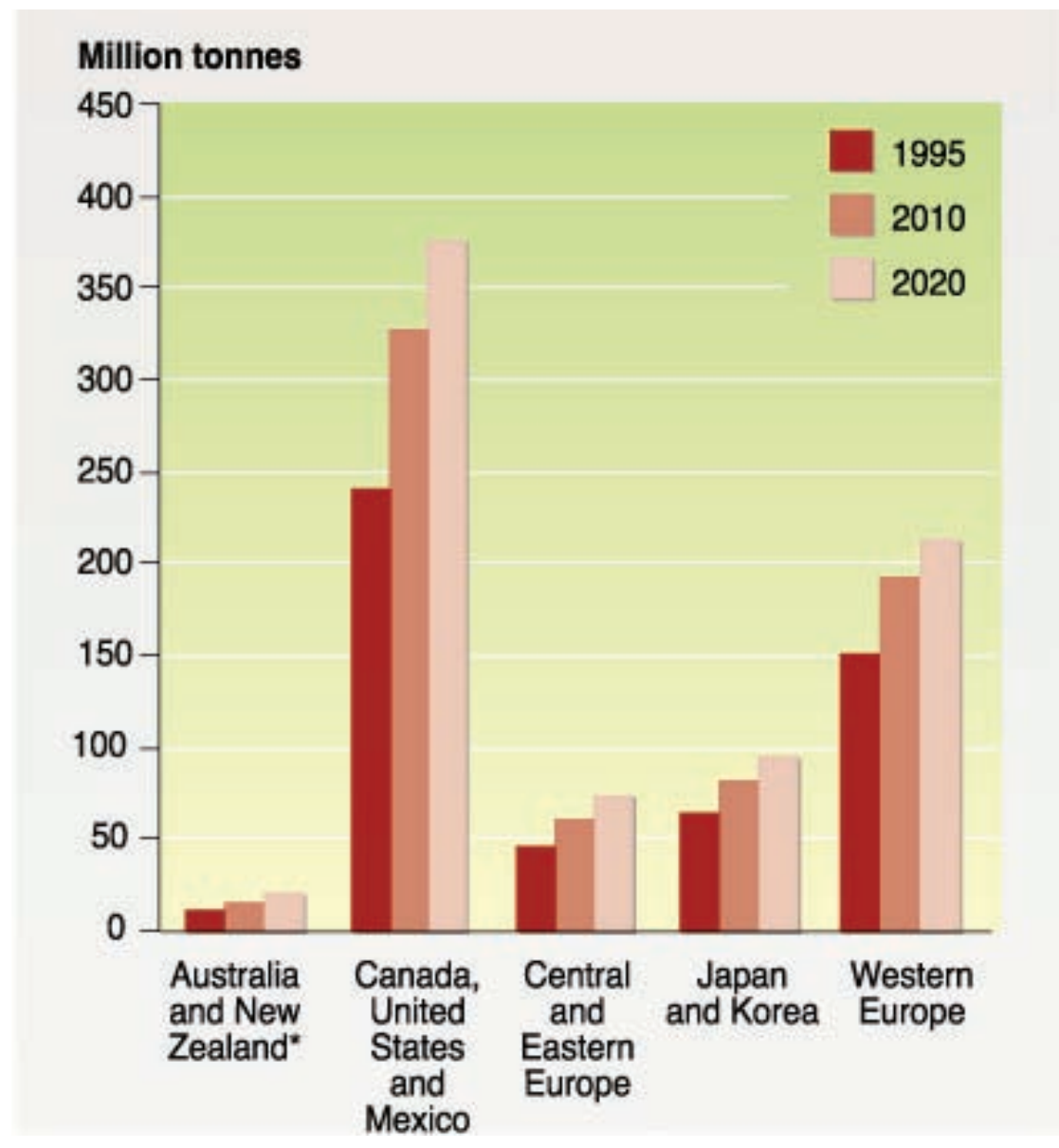

*Data for Australia and New Zealand is an expert estimate. Source: OECD, 2004a

Figure 1. Trends in municipal solid waste (MSW) generation. 


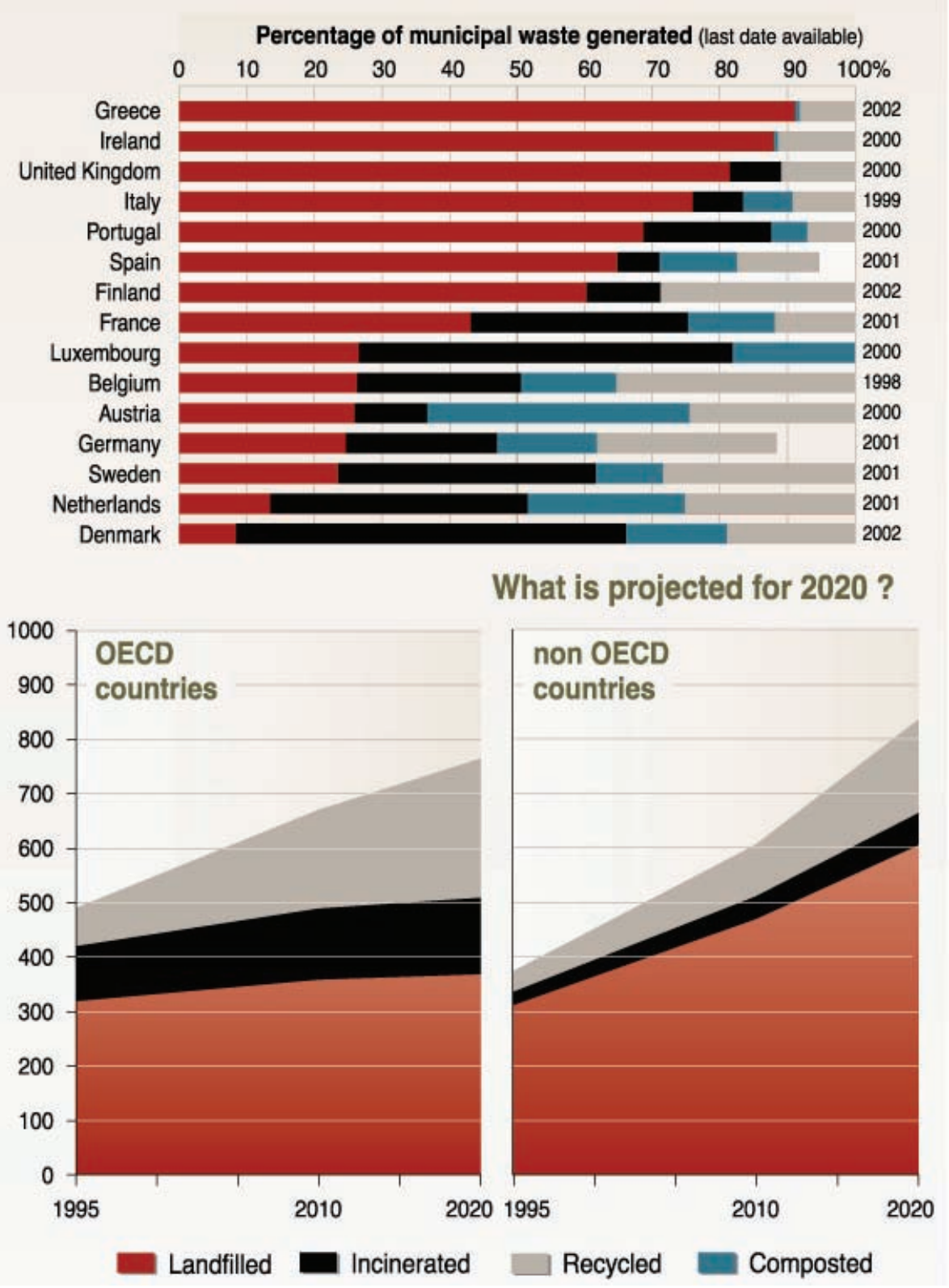

Source OECD (2004b)

Figure 2. Waste treatment options for OECD and non-OECD countries.

Most developed countries have enacted strict laws and regulations that established the obligatory capture and treatment of leachate and landfill gases in order to reduce such harmful effects. The European Union, through the Commission for Waste Management, has established several Directives such as Council Directive 75/442/EEC on waste and Council Directive 
99/31/EC on the landfilling of waste. These Directives set operational and technical requirements aiming to protect human health and the environment from the negative impacts of landfilling of waste (EUC, 1996; OJEC, 1999, 2003). In the European waste management hierarchy, the landfilling of waste is the least preferred treatment option due to the space requirements involved, the need of aftercare in perpetuity, the loss of material resources, and the pollution caused by the leachate and biogas from landfill sites (EUC, 1996). Despite all these facts, landfills are necessary components of the waste management system because landfills are the most flexible, cheap and reliable method of waste containment/treatment. However, the physical barriers of landfills will eventually fail in the long-term leading to a penetration of moisture (i.e. rainfall) and will trigger all restrained physical, chemical and biological processes and consequently contaminants would be released, threatening human health and the environment (Westlake, 1997; Koerner and Soong, 2000; Allen, 2001; Benson et al, 2007). Since it is expected that this event occurs after the legally required monitoring period has finished ( $>50$ years after landfill closure), an economic and environmental burden will be transferred to the next generations, contradicting the precepts of sustainability (WCED, 1987; Westlake, 1997; Burton and Watson-Craik, 1998; Williams, 1998; Barlaz et al, 2002). Several researchers have foreseen such problems and attempted to develop new approaches to overcome these landfill concerns. As a result of their investigations better containment systems, improved leachate and landfill gas capture and treatment systems were developed (Katsumi et al, 2000; Koerner and Soong, 2000; Simon and Müller, 2004). Nevertheless, future pollution problems associated with entombed waste have so far not been solved. Research, conducted over the last three decades has attempted, the introduction of a new design of landfill, to reduce the stabilisation time to a more reasonable time scale (30 years), to decrease the costs of leachate treatment, to increase landfill gas generation and to reduce landfill lifetime through landfill-space reclamation and to achieve a final product that no longer is a threat to the surrounding environment (Baccini, 1988; Brunner, 1988; Döberl et al, 2001). Based on these new approaches the so-called bioreactor landfill concept was conceived (Figure 3). The bioreactor landfill is a system that is operationally influenced to promote synergy between the inherent microbial consortia, and it is controlled to accelerate the sequential phases of waste stabilisation through the addition of liquids and/or air 
(Pohland, 1980 and 1996; Reinhart and Townsend, 1998; Warith, 2000; USEPA, 2003).

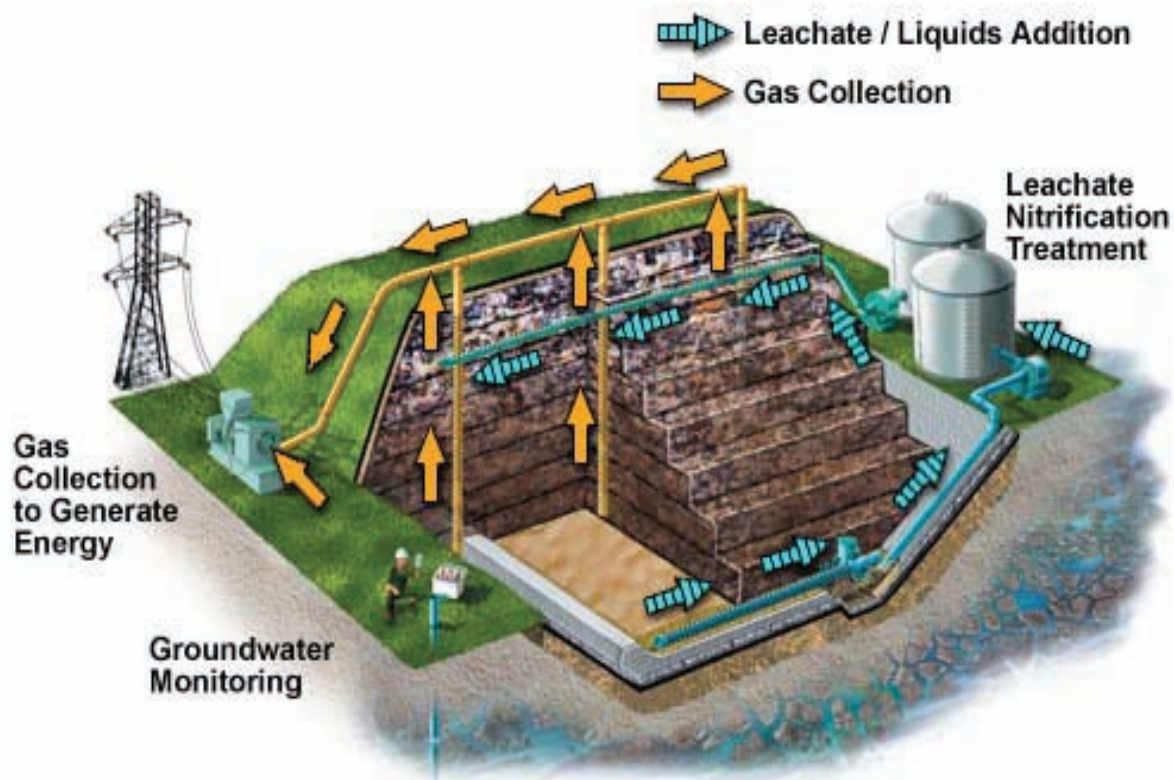

Courtesy of Waste Management

Source: USEPA, 2003.

Figure 3. Schematic view of a modern anaerobic bioreactor landfill.

\section{Factors controlling waste stabilisation}

Research conducted during the last three decades has made possible to identify the key process parameters that influence the waste stabilisation process in bioreactor landfills as shown in Table 2. Moisture content and $\mathrm{pH}$ of the system appear to be the most important parameters. In practice, constant recirculation tends to cool-down the system to temperatures in the range of 20 to $30^{\circ} \mathrm{C}$. Nutrients are generally adequate in most landfills except in nutrient-deficient pockets due to waste heterogeneity (Yuen, 1999). Moderate to severe inhibition can be caused by macronutrients, heavy metals and organic compounds in the leachate if present above certain concentrations (Reinhart and Townsend, 1998; Kjeldsen et al, 2002). 
Table 2. Key parameters for waste degradation in bioreactor landfills.

\begin{tabular}{|c|c|}
\hline Influencing factors & Optimal ranges/comments \\
\hline Moisture & $\begin{array}{l}\text { Generally above field capacity }{ }^{1} \text { : } \\
55-75 \% \text { by wet weight }\end{array}$ \\
\hline $\mathrm{pH}$ & $6.5-7.5$ \\
\hline Temperature & $32^{\circ} \mathrm{C}-38^{\circ} \mathrm{C}$ \\
\hline Density & $800-1000 \mathrm{~kg} \mathrm{~m}^{-3}$ \\
\hline Nutrients & $\begin{array}{l}\text { Generally adequate except local nutrient- } \\
\text { deficient pockets due to heterogeneity }\end{array}$ \\
\hline \multirow[t]{8}{*}{ Inhibitors } & $\begin{array}{l}\text { Cation concentration producing moderate/severe } \\
\text { inhibition }\left(\mathrm{mg} \mathrm{L}^{-1}\right) \text { : }\end{array}$ \\
\hline & $3500-5500$ \\
\hline & Potassium \\
\hline & $2500-4500$ \\
\hline & Magnesium \\
\hline & Ammonium (total) \\
\hline & Heavy metals: no significant influence \\
\hline & $\begin{array}{l}\text { Organic compounds: inhibitory effect only in } \\
\text { significant amount }\end{array}$ \\
\hline
\end{tabular}

After: McCarty and McKinney, 1961; Ham et al, 1978; Leckie et al, 1979; Pohland, 1980; Ham and Bookter, 1982; Hartz et al, 1982; Gurijala and Suflita, 1993; Benson et al, 2007

\section{Enhancement techniques for enhanced waste stabilisation}

These key process parameters are greatly influenced by the operational conditions implemented to enhance the biological process of waste, the so-called enhancement techniques. Liquid addition and recirculation is the most used enhancement technique to increase moisture content, to redistribute microorganisms and nutrients within the waste matrix and to dilute locally high concentrations of inhibitory substances. Other enhancement techniques used, to a lesser extent, are waste shredding, selection/control, addition of buffers and sludge. Despite the fact that, originally the main objective of waste shredding was to increase waste density and gain valuable landfill volume (Ham et al, 1978; El-Fadel et al, 2002), shredding proved to be beneficial for the waste stabilisation process since increased homogeneity and the waste surface area also helped to remove moisture barriers caused by impermeable materials (i.e. plastic bags). Nevertheless, shredding of waste is not sufficient to achieve complete

\footnotetext{
${ }^{1}$ Field capacity is the amount of liquids that a solid can retain free of drainage against the gravity forces
} 
waste stabilisation if it is not combined with other enhancement techniques (i.e. liquid recirculation). Additionally, shredding of waste is an intensive and expensive activity. Control and selection of waste refers to wastes of different compositions "constructed" to increase availability of moisture and substrate and to decrease the presence of potential inhibitors (Yuen et al, 2001). Nilsson et al (1995) demonstrated that control/selection of inert waste led to better performance of the reactor and improved geotechnical stability, which is necessary to avoid slope failure of the waste mass. Buffer addition aiming to maintain neutral $\mathrm{pH}$ of the system is practiced because, due to unbalanced landfill ecosystems, low $\mathrm{pH}$ values can inhibit the methanogenic activity. Laboratory experiments have demonstrated that addition of buffers has a positive effect on the degradation process (Kinman et al, 1987; Bramryd, 1995). The addition of biosolids such as raw sewage sludge or treated wastewater treatment plant (WWTP) sludge can provide additional moisture to the waste mass, microorganisms and nutrients and can act as buffer to maintain a neutral $\mathrm{pH}$. Extensive research has been carried out with addition of sludge, mainly WWTP sludge, with positive impacts on the waste stabilization process and enhanced biogas production (Pohland, 1980; Reinhart and Townsend, 1988, Campbell, 1991; Bae et al, 1998; Chan et al, 1999, Knox et al, 2000; Çinar et al, 2004; Silva et al, 2004; Hartmann and Ahring, 2005; Bolzonella et al, 2006). Nevertheless, little is known about the effects of different types of sludge/materials such as septic tank sludge or slaughterhouses waste (rumen content) on the waste stabilisation process. However, its practical application depends strongly on the waste regulations for different site locations.

In order to achieve the Millennium Development Goals (MDG) on sanitation approximately 1.6 billion people should gain access to improved sanitation options ${ }^{2}$ by the year 2015 (WHO/UNICEF, 2006). This amount of people will generate an impressive amount of septage ${ }^{3}$ that need to be handled, treated and disposed; for instance, only United States of America generates annually approximately $21 \cdot 10^{6} \mathrm{~m}^{3}$ of septage (USEPA, 1999). Current septage management options like composting, anaerobic digestion

\footnotetext{
${ }^{2}$ Improved sanitation options refer to public sewer connection, septic system connection, pour-flush latrine, simple pit latrine and ventilated improved pit latrine.

${ }^{3}$ Septage is the solids (sludge), scum and greases pumped from a septic tank, cesspool or other primary treatment source.
} 
and chemical treatment will be overloaded. Most of these options are, apparently, not financially feasible in developing countries because most septage is still discharged indiscriminately into lanes, drainage ditches, sewer networks, onto open urban spaces, and into fresh and marine water bodies, causing serious environmental and health impacts (Bradley, 1981; Chen, 1988). Since septage is already separated from its liquid counterpart it should remain in the solid treatment pathway (i.e. landfill disposal). Despite the fact that few experiments on septage co-disposal generated inconclusive results or even suggested negative impacts on the waste degradation process (Leckie et al, 1979; Leuschner, 1989) none of them were carried out with leachate recirculation as enhancement option.

All these enhancement techniques have a positive effect on the waste stabilisation process. However, all of them require to be combined with liquid recirculation in order to be effective and efficient. Liquid, usually leachate, recirculation is carried out following several operational strategies like recirculation without amendments, different recirculation rates, different leachate age, temperature control and treatment of leachate prior to recirculation.

\subsection{Strategies for liquid recirculation}

Liquid recirculation in landfills enhances hydrolysis of organic matter, but limitations in the buffer capacity of the system may cause $\mathrm{pH}$ values to drop, as a result of the accumulation of volatile fatty acids. Low $\mathrm{pH}$ may inhibit the methanogenic bacteria ceasing the biogas production (Kinman et al, 1987; Veeken et al, 2000; Yuen, 2001). Experiments have shown that recirculation at higher rates enhances the waste stabilisation process. However, on the long-term there is the risk of accumulation of microorganisms and nutrients at specific areas (i.e. at the bottom) of the landfill body, causing an unbalance, leading to a microbiological collapse of the entire system (Leckie et al, 1979; Pohland, 1980; Klink et al, 1982; Reinhart and Al-Yousfi, 1996; Mehta et al, 2002). Recirculation of leachate of different ages has a positive effect on the waste degradation process. Addition of mature leachate to fresh waste triggers methanogenic conditions in a relatively short period (Oonk and Woelders, 1999; Vroon et al, 1999). Well decomposed waste and the established bacterial population were able 
to cope with higher concentrations of hydrolytic products that otherwise would delay the start up of methane production (Pohland and Kim, 1999; O'Keefe and Chynoweth, 2000). However, constant recirculation of old leachate may cause a build-up of inorganic salts and nitrogen compounds to inhibitory levels in the long term (Burton and Watson-Craik, 1998; Caine et al, 1999; Price et al, 2003; Berge et al, 2005). Leachate temperature control (heating of leachate) is not widely practiced because of the high costs associated with this activity (De Rome and Gronow, 1995). Furthermore, heat exchange between liquids and solids was limited to a certain radius of influence from the injection point. Field data has shown marked differences in temperature profiles of waste versus depth as a consequence of the cooling effect of recirculation (De Rome and Gronow, 1995; Yazdani et al, 2006). Treatment of the leachate to reduce concentrations of potential inhibitors, such as ammonium, either aerobically or anaerobically, prior to recirculation has shown to have a positive influence on the waste stabilisation process (Burton and Watson-Craik, 1998; Onay and Pohland, 1998; O'Keefe and Chynoweth, 2000; Yuen et al, 2001; Jokela et al, 2003; He et al, 2007)

Nevertheless, the effectiveness of leachate recirculation may depend on the efficacy of the method chosen for leachate infiltration, the hydraulic properties of waste and the existence of preferential flow pathways in the waste matrix. As previously mentioned moisture content has been suggested as the most important factor for biodegradation in landfills (Klink et al, 1982; Gurijala and Suflita, 1993). However, the main problem that has been identified refers to the homogenous distribution of the recirculated liquid into the waste matrix (Reinhart and Al-Yousfi, 1996; McCreanor and Reinhart, 1999; Miller and Clesceri, 2003; Morris et al, 2003). The different methods of leachate recirculation, tested at field scale, have presented a series of operational problems. Water surface irrigation and ponds experienced high evaporative losses and odour related problems. Buried drip systems have led to microbiological clogging and pipelines fracture due to differential settlement. Horizontal trenches and vertical wells showed also clogging and low influence area (McCreanor and Reinhart, 1999; Yuen, 1999). However, recent developments have shown that a combination of trenches and vertical wells, the use of hydraulic blankets and different modi operandi (alternated operational times) helped to extend the influence area of 
the recirculation systems, hence increasing the waste stabilisation rates (Townsend et al, 1995; Reinhart and Al-Yousfi, 1996; Miller and Emge, 1997; Reinhart and Townsend, 1998; McCreanor and Reinhart, 1999; Pouech et al, 1999; Warith et al, 2001; Haydar and Khire, 2005; Yazdani et al 2006; Benson et al, 2007; Khire and Mukherjee, 2007)

Waste hydraulic properties and preferential flow pathways have been extensively studied by several researchers (Williams, 1998; McCreanor and Reinhart, 1999; Yuen et al, 2001; Miller and Clesceri, 2003; Yazdani et al, 2006). These authors suggested that waste hydraulic conductivity, ideally in the range of $10^{-3}$ to $10^{-6} \mathrm{~cm} \mathrm{sec}^{-1}$, changes with time as the waste particles are reduced and available pores collapsed, and therefore the efficacy of recirculation is reduced substantially. The other factor affecting homogenous liquid distribution is the "channelling" phenomenon, in which the liquid tends to follow preferential pathways leaving some dry areas within the waste bulk, thus reducing the overall waste stabilisation rate (McCreanor and Reinhart, 1999; Rosqvist and Destouni, 2000; Rosqvist et al, 2005). Modification of the waste hydraulic properties for instance by mixing with coarse materials can help to enhance the homogenous liquid distribution; however at large scale, this approach seems neither technically nor economically feasible. An alternative approach is the use of intermediate layers of coarse materials that help to break the channelling effect and to redistribute homogenously the liquids within the waste matrix. Utilising coarse materials can provide structural capacity to the waste matrix in order to overcome geotechnical stability problems mentioned by Bramryd (1995) and Nilsson et al (1995).

A reliable method of liquid infiltration that ensures constant and homogenous liquid distribution is the key for the successful application of enhancement techniques in order to achieve a stable residue, the so-called final storage quality (FSQ) of waste.

\section{The final storage quality (FSQ) of waste residues}

Despite the fact that there is no general consensus on a clear definition and there are also no methods of measurement, the term FSQ suggests that the potential of a waste material to produce pollution is reduced to nearly 
zero in the long-term perspective (Baccini, 1988; Brunner, 1988). In that context, waste residues in (bioreactor) landfills have achieved FSQ status when the residue properties resemble those of the surrounding environment (i.e. rock-like material) or when it is solid, non-reactive, present in an oxidised form and poorly soluble in water (Pfiffner, 1988; Ulrich et al, 1988). This suggests that these landfills will not require maintenance and monitoring in the long-term as it is usually necessary for regular sanitary landfills (Sabbas et al, 1999; Döberl et al, 2001). Neither American nor European legislation, including the Landfill Directive, explicitly define the criteria to declare FSQ status or the necessary timeframes to reach it. Despite all these legal limitations, several researchers have attempted to define FSQ characteristics of residues that lead to safe closure of landfill sites (Table 3) (Lo, 1996; Reinhart and Townsend, 1998; Shearer, 2001; Barlaz et al, 2002; Boda, 2002; François et al. 2006), but little information is available regarding the physical, chemical and biological characteristics of waste residues from bioreactor landfills.

Table 3. Proposed waste stability characteristics for secure landfill closure.

\begin{tabular}{ll}
\hline Parameter & Range \\
\hline Biological methane potential (BMP) & $0.05-0.15 \mathrm{~m}^{3} \mathrm{CH}_{4}$ ton $^{-1}$ waste \\
Volatile solids content & $18-19 \%$ of dry waste \\
$\mathrm{BOD} / \mathrm{COD}$ ratio & $0.1-0.25$ \\
$\mathrm{SO}_{4}{ }^{2-} / \mathrm{Cl}^{-}$ratio & $<0.05$ \\
Cellulose/lignin ratio & $0.1-0.2$ \\
Physical appearance & Dark sludge-like \\
\hline
\end{tabular}

After: Lo, 1996; Reinhart and Townsend, 1998; Shearer, 2001; Barlaz et al, 2002; Boda, 2002; François et al. 2006

Nitrogen compounds, especially ammonium, have been identified as a main parameter that will jeopardise the achievement of FSQ status, hence the safely closure of landfill sites (Barlaz et al, 2002). Ammonium, an end product of protein (MSW) degradation (Burton and Watson-Clark, 1998; Jokela and Rintala, 2003; Jokela et al, 2005; Berge et al, 2005), tends to accumulate in landfill leachates since there are no effective removal mechanisms under anaerobic conditions. Huber et al (2004) suggested that approximately only $4 \%$ of nitrogen leaves the landfill site via the leachate pathway, while $96 \%$ of nitrogen remains in the waste matrix. All nitrogen 
removal research has focused on the liquid (leachate) fraction of the landfill, leaving unattended the nitrogen solid fraction. There is no literature available about the fate and nature of nitrogen remaining in the solid fraction and the possible technological options to remove it. Therefore, it is of outmost importance to know more about the nitrogen generation, transformations and removal mechanisms in order to attain the FSQ status of waste residues. Leachate nitrogen removal methods ranged from classical ex-situ nitrification and denitrification, chemical precipitation, in-situ nitrification and denitrification to nitrogen recovery as nutrient at energy forests (Jokela et al, 2002; Li and Zhao, 2003; Brander et al, 2004; Kurniawan et al, 2006; He et al, 2007). Either in-situ or partially in-situ approaches are likely to produce $\mathrm{NO}_{\mathrm{x}}$ and $\mathrm{N}_{2} \mathrm{O}$ (Price et al, 2003). The quantities produced are insignificant $\left(<0.1 \%\right.$ by volume), compared to the amount of $\mathrm{CO}_{2}$ and $\mathrm{CH}_{4}$, the main components of landfill gas which are also greenhouse gases (Palmisano and Barlaz, 1996, Evans, 2001; Tchobanoglous and Kreith, 2002). However, their global warming potential, which is about 200 times greater than that of $\mathrm{CO}_{2}$, made them significant pollutants for their contribution to the climate change. It has been estimated that landfill sites contribute to approximately $3-5 \%$ of anthropogenic greenhouse gases emissions of the world (Figure 4) (Kumar et al, 2004; Bogner et al, 2007, UN, 2007).

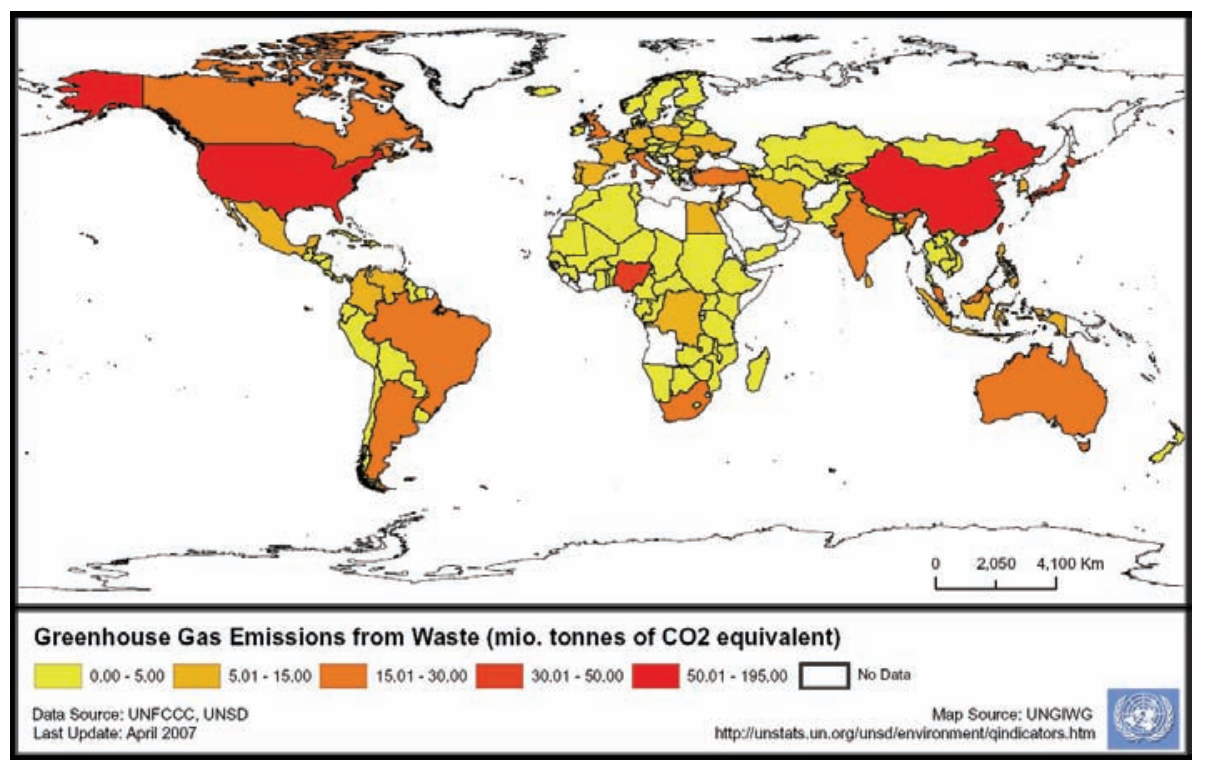

Figure 4. Worldwide map of greenhouse gas emissions from solid waste. 


\section{Motivation and scope of the thesis}

Currently Dutch landfill operators are eager to demonstrate to the environmental agencies responsible of secure landfill closure that landfills can be safely closed and probably reused for recreational or commercial purposes without the need to continue in perpetuity monitoring and maintenance of the sites. With this aim, the Dutch foundation for sustainable landfilling (Stichting Duurzaam Storten), established by all major Dutch waste operators, has carried out, since 1999, a series of laboratory and fieldscale experiments aiming to design and operate a (bioreactor) landfill in which the pollution produced will be below environmental standards after a barrier failure event in the mid or long term (Figure5). Significant results have been achieved during the last 7 years, but important problems have not been solved, such as the homogenous liquid distribution and the achievement of a residue with such characteristics that resemble those mentioned in the Waste Acceptance Criteria (WAC) of the Landfill Directive for inert waste (OJEC, 2003). The reason to compare the residues with inert waste standards is because inert waste landfills face less strict closure regulations and therefore long-term monitoring schemes can be avoided, which in turn will result in savings of several hundreds millions of euros for the Dutch waste operators.

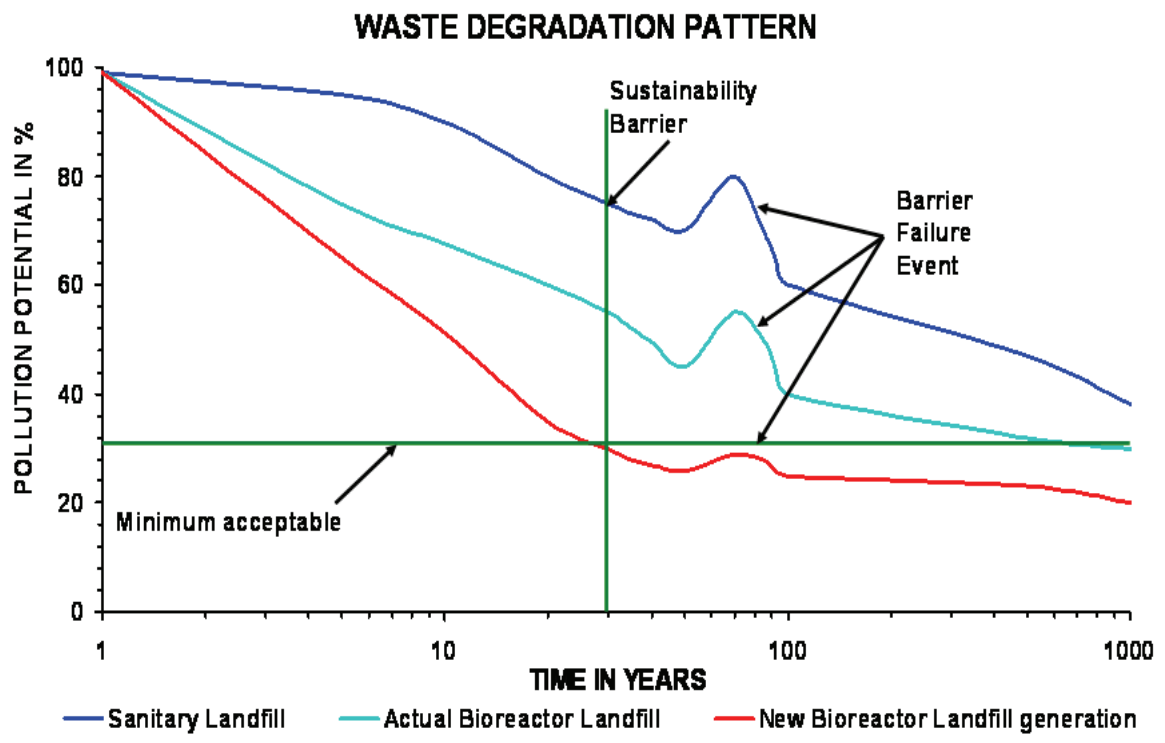

Figure 5. Final Storage Quality projection in an efficient bioreactor landfill. 
Effective and reliable methods of liquid infiltration that ensures homogenous liquid distribution apparently are the basis for the success of the enhancement techniques, which supposedly will lead to the achievement of FSQ of waste materials placed in bioreactor landfills.

\section{Objectives of the thesis}

The main objective of this thesis was to achieve a FSQ status of waste, through laboratory and pilot-scale experiments, that complies with the WAC of the Landfill Directive for Inert waste, which had been considered as the worst-case scenario due to the stringent criteria established. Therefore, this thesis focused on the interaction and modification of the factors controlling the waste stabilisation process in order to have a better understanding of the physical, chemical and biological processes occurring in a bioreactor landfill.

The specific objectives of this thesis were:

- To investigate the effect of different combinations of enhancement techniques (waste shredding, $\mathrm{pH}$ control, bio-solid addition with leachate recirculation) on the waste stabilisation process.

- To evaluate the effect of intermediate layers of coarse material and homogenous mixtures on the improvement of homogenous moisture distribution in the solid waste matrix.

- To assess the evolution, fate and in-situ removal of nitrogen compounds from the solid waste matrix.

\section{Outline of the thesis}

This thesis comprises seven chapters. Chapter 1 provides the current state-of-knowledge of the key process parameters, enhancement techniques and leachate recirculation methods employed to achieve the FSQ status of waste residues in bioreactor landfills. Chapter 2 presents the performance of pilot-scale simulators aiming to achieve FSQ of waste residues; it focuses on the carbon and nitrogen transformations and evaluates the factors influencing the achievement of FSQ status in the simulators. The effects of septic tank sludge addition on the stabilisation process of municipal solid waste are discussed in Chapter 3. Factors influencing the removal of coliforms are also discussed. Chapter 4 reports on the changes of hydraulic conditions and their 
impact on the waste stabilisation process. The evolution and fate of nitrogen in bioreactor landfills are shown in Chapter 5. This chapter focuses on the release and possible removal mechanisms from the solid phase, especially on the development of Anammox bacteria in the simulators. Chapter 6 presents the results of an existing mathematical model that describes the carbon and nitrogen transformations occurring in the simulators. Finally, chapter 7 presents the conclusions and the practical implications of this research and an outlook for future research.

\section{References}

Allen A. (2001). Containment Landfills: the myth of sustainability. Eng. Geol. 60, 3-19.

Baccini P. (1988). Conclusions and outlook In "The Landfill, Reactor and Final Storage", p.p. 425, Swiss Workshop on Land Disposal of Solid Wastes, Gerzenzee, March 14-17, 1988, P Baccini (Ed.), Springer-Verlag, Berlin.

Bae J.H., Cho K.W., Lee S.J., Bum B.S., Yoon B.H. (1998). Effects of leachate recycle and anaerobic digester sludge recycle on the methane production from solid waste. Water Sci. Technol. 38(2), 159-168.

Barlaz M.A., Rooker A.P., Kjeldsen P., Gabr M.A., Borden R.C. (2002). Critical evaluation of factors required to terminate the postclosure monitoring period at solid waste landfills. Environ. Sci. Technol. 36, $3457-$ 3464.

Barlaz M.A., Ham R.K., Schaefer D.M. (1989). Mass-balance analysis of anaerobically decomposed refuse. J. Environ. Eng.-ASCE. 115,1088-1102.

Benson C.H., Barlaz M.A., Lane D.T., Rawe J.M. (2007). Practice review of five bioreactor/recirculation landfills. Waste Manage. 27, 13-29.

Berge N.D., Reinhart D.R., Townsend T.G. (2005). Fate of nitrogen in bioreactor landfills. Crit. Rev. Env. Sci. Technol. 35, 365-399.

Boda B. (2002). Evaluation of Stability parameters for Landfills. Master in Science Thesis, Virginia Polytechnic Institute and State University, USA. http:/scholar.lib.vt.edu/theses/available/etd-08072002-

120127/unrestricted/Thesis.pdf (Accessed December 2007)

Bolzonella D., Battistoni P., Susini C., Cecchi F. (2006). Anaerobic codigestion of waste activated sludge and OFMSW: the experiences of Viareggio and Treviso plants (Italy). Water Sci. Technol. 53(8), 203-211. 
Bradley R.M. (1981). Disposal of septic tank contents in Cyprus. Water Pollut. Control. 80, 131-137.

Brander L., Dahl M., Bramryd T. (2004). Irrigation of landfill leachates in energy forests- A technique to recover nutrients from municipal solid wastes. Water, Air Soil Poll. 154, 213-224.

Bramryd T. (1995). Landfill bioreactor- a future technique for extraction of energy and nutrients from municipal solid wastes In ISWA $25^{\text {th }}$ Anniversary conference, October, 15-20, Vienna, Austria.

Bogner J., Abdelrafie M.A., Diaz C., Faaij A., Gao Q., Hashimoto S., Mareckova K., Rippati R., Zhang T. (2007). Waste Management In Metz B., Davidson O.R., Bosh P.R., Dave R., Meyer L.A. (Eds.) Climate Change 2007: Mitigation. Contribution of Working Group III to the Fourth Assessment Report of the Intergovernmental Panel on Climate Change. Cambridge University Press, Cambridge, UK and New York, NY, USA.

Brunner P.H. (1988). Methodology for the evaluation of the final storage quality-introduction In "The Landfill, Reactor and Final Storage”, p.p. 359, Swiss Workshop on Land Disposal of Solid Wastes, Gerzenzee, March 14-17, 1988, P. Baccini (Ed.), Springer-Verlag, Berlin.

Burton S.A.Q., Watson-Craik I.A. (1998). Ammonia and nitrogen fluxes in landfill sites: applicability to sustainable landfilling. Waste Manage. Res. $16,41-53$.

Buswell A.M., Mueller M.F. (1952). Mechanisms of methane fermentation. Ind. Eng. Chem. 44, 550-552.

Caine M., Campbell D., Van Santen A. (1999). The landfill gas timeline: the Brogborough test cells. Waste Manage. Res. 17, 430-440.

Campbell D.J.V., Croft B.C. (1991). Landfill gas enhancement: Brogborough test cell programme In Conference Proceedings: Landfill gas, energy and environment '90, DoE, UK.

Chan Y.S.G., Chu L.M., Wong M.H. (1999). Codisposal of municipal refuse, sewage sludge and marine dredgings for methane production. Environ. Pollut. 106, 123-128.

Chen M. (1988). Pollution of groundwater by nutrients and fecal coliforms from lakeshore septic tank systems. Water Air Soil Pollut. 37, 407-417.

Çinar S., Onay T.T., Erdinçler A. (2004). Co-disposal alternatives of various municipal wastewater treatment-plant sludges with refuse. Adv. Environ. Res. 8, 477-482. 
De Rome L., Gronow J. (1995). Leachate recirculation in the UK an overview of research projects. In T.H. Christensen, R. Cossu, R. Stegmann (Eds.): Sardinia 1995 "Fifth International Landfill Symposium", October 2-6, 1995, S. Margherita di Pula, Cagliari, Italy.

Döberl G., Huber R., Brunner P.H., Eder M., Pierrard R., Schönbäck W., Frühwirth W., Hutterer H. (2002). Long-term assessment of waste management options - a new, integrated and goal-oriented approach, Waste Manage. Res. 20, 311-327.

Ehring H.J. (1983). Quality and quantity of sanitary landfill leachate. Waste Manage. Res. 1, 53-68.

EUC (1996). European Union Commission: Handbook for Implementation of EU environmental legislation, p.p. 1-130.

http://www.europa.eu.int/comm./environment/enlarg/handbook/handbook. htm (Accessed September 2004).

El-Fadel M., Bou-Zeid E., Chahine W., Alayli B. (2002). Temporal variation of leachate quality from pre-sorted and baled municipal solid waste with high organic and moisture content. Waste Manage. 22, 269-282.

Evans G. (2001). Biowaste and biological waste treatment. James \& James Science Publishers, London, UK.

Francois V., Feuillade G., Skhiri N., Lagier T., Matejka G. (2006). Indicating the parameters of the state of degradation of municipal solid waste. J. Hazard. Mater. 137, 1008-1015.

Gurijala K.R., Suflita J.M. (1993). Environmental factors influencing methanogenesis from refuse in landfill samples. Environ. Sci. Technol. 27, 1178-1181.

Ham R.K., Bookter T.J. (1982). Decomposition of solid waste in test lysimeters. J. Environ. Eng-ASCE. 108, 1147-1170.

Ham R.K., Reinhardt J.J., Sevick G.W. (1978). Density of milled and unprocessed refuse. J. Environ. Eng-ASCE. 104, 109-125.

Hartmann H., Ahring B.K. (2005). Anaerobic digestion of the organic fraction of municipal solid waste: Influence of co-digestion with manure. Water Res. 39, 1543-1552.

Hartz K.E., Klink R.E., Ham R.K. (1982). Temperature effects: methane generation from landfill samples. J. Environ. Eng-ASCE. 108, 629-638.

Haydar M.M., Khire M.V. (2005). Leachate recirculation using horizontal trenches in bioreactor landfills. J. Geotech. Geoenviron. 131, 837-847. 
He P.-J., Qu X., Shao L.-M., Li G.-J., Lee D.-J. (2007). Leachate pretreatment for enhancing organic matter conversion in landfill bioreactor. J. Hazard. Mater. 142, 288-296.

He R., Liu X.-W., Zhang Z.-J., Shen D.-S. (2007). Characteristics of the bioreactor landfill system using an anaerobic-aerobic process for nitrogen removal. Bioresour. Technol. 98, 2526-2532.

Huber R., Fellner J., Döeberl G., Brunner P. (2004). Water flows of MSW landfills and implications for long-term emissions. J. Environ. Sci. Health. A39, 885-900.

Johannessen L.M. (1999). Guidance note on recuperation of landfill gas from municipal solid waste landfills. Working Paper Series Vol. 4, World Bank, USA.

Jokela J.P.Y., Kuttunen R.H., Sormunen K.M., Rintala J.A. (2002). Biological nitrogen removal from municipal landfill leachate: low-cost nitrification in biofilters and laboratory scale in-situ denitrification. Water Res. 36, 4079-4087.

Jokela J.P.Y., Rintala J.A. (2003). Anaerobic solubilisation of nitrogen from municipal solid waste. Rev. Environ. Sci. Biotechnol. 2, 67-77.

Jokela J.P.Y., Vavilin V.A., Rintala J.A. (2005). Hydrolysis rates, methane production and nitrogen solubilisation of grey waste components during anaerobic degradation. Bioresour. Technol. 96, 501-508.

Katsumi T., Benson C.H., Foose G.J., Kamon M. (2001). Performance-based design of landfill liners. Eng. Geol. 60, 139-148.

Khire M.V., Mukherjee M. (2007). Leachate injection using vertical wells in bioreactor landfills. Waste Manage. 27, 1233-1247.

Kinman R.N., Nutini D.L., Walsh J.J., Vogt W.G., Stamm J., Rickabaugh J. (1987). Gas enhancement techniques in landfill simulators. Waste Manage. Res. 5, 13-25.

Kjeldsen P., Barlaz M.A., Rooker A.P., Baun A., Ledin A., Christensen T.H. (2002). Present and Long-Term Composition of MSW Landfill Leachate: A Review. Crit. Rev. Env. Sci. Technol. 32, 297-336.

Klink R.E., Ham R. (1982). Effects of moisture movement on methane production in solid waste landfill samples. Resour. Conserv. 8, 29-41.

Knox K., Knox Associates (2000). Sustainable Landfill in the U.K.: a review of current knowledge and outstanding R\&D needs, p.p. 1-31, http:/www.deponie- 
stief.de/fachlit/forschung/txfe/ausland/uk/esart/knox_report.pdf (Accessed August 2004)

Koerner R.M., Soong T.-Y. (2000). Leachate in landfills: the stability issues. Geotex. Geomembranes. 18, 293-309.

Kumar S., Gaikwad S.A., Shekdar A.V., Kshirsagar P.S., Singh R.N. (2004). Estimation method for national methane emission from solid waste landfills. Atmos. Environ. 38, 3481-3487.

Kurniawan T.A., Lo W.H., Chan G.Y.S. (2006). Physico-chemical treatments for removal of recalcitrant contaminants from landfill leachate. J. Hazard. Mater. B129, 80-100.

Leckie J.O., Pacey J.G., Halvadakis C. (1979). Landfill management with moisture control. J. Environ. Eng-ASCE. 105, 337-355.

Li X.Z, Zhao Q.L. (2003). Recovery of ammonium-nitrogen from landfill leachate as a multinutrient fertilizer. Ecol. Eng. 20, 171-181.

Lo I.M.-C. (1996). Characteristics and treatments of leachates from domestic landfills. Environ. Int. 22, 433-442.

McCarty P.L., McKinney R.E. (1961). Salt toxicity in anaerobic digestion. $J$. Water Pollut. Fed. 33, 399-415.

McCreanor P.T., Reinhart D.R. (1999). Hydrodynamic modeling of leachate re-circulating landfills. Waste Manage. Res. 17, 465-469.

Mehta R., Barlaz M.A., Yazdani R., Augenstein D., Bryars M., Sinderson L. (2002). Refuse decomposition in the presence and absence of leachate recirculation. J. Environ. Eng-ASCE. 128, 228-236.

Miller P.A., Clesceri N.L. (2003). Waste sites as biological reactors: characterization and modelling. Lewis Publishers, New York, U.S.A.

Miller D.E., Emge S.M. (1997). Enhancing landfill leachate recirculation system performance. Pract. Period. Hazard. Toxic Radioact. Waste Manage. 1, 113-119.

Morris J.W.F., Vasuki N.C., Baker J.A., Pendleton C.H. (2003). Findings from long-term monitoring studies at MSW landfill facilities with leachate recirculation. Waste Manage. 23, 656-666.

Nilsson P., Karlsson H., Lagerkvist A., Meijer J.E. (1995). The coordinated Test Cell program in Sweden. In T.H. Christensen, R. Cossu, R. Stegmann (Eds.): Sardinia 1995 "Fifth International Landfill Symposium" October 2-6, 1995, S. Margherita di Pula, Cagliari, Italy. Nolan K. (2002). Biodegradable waste: a challenge ahead for Europe. Waste Manage. World Magazine 2, 13-18. 
O'Keefe D.M., Chynoweth D.P. (2000). Influence of phase separation, leachate recycle and aeration on treatment of municipal solid waste in simulated landfill cells. Bioresour. Technol. 72, 55-66.

OECD (2004a). Projected trends in regional municipal waste generation. UNEP/GRID-Arendal Maps and Graphics Library, Philippe Rekacewicz (Cartographer).

http://maps.grida.no/go/graphic/projected_trends_in_regional_municipal_ waste_generation (Accessed December, 2007).

OECD (2004b). Landfilling and incinerating still leading in Europe. UNEP/GRID-Arendal Maps and Graphics Library, Philippe Rekacewicz (Cartographer).

http://maps.grida.no/go/graphic/landfilling_and_incinerating_still_leading _in_europe (Accessed December 2007)

OECD (2007). Environmental data 2007, Compendium 2006-2007. http://unstats.un.org/unsd/ENVIRONMENT/wastetreatment.htm (Accessed December 2007).

OJEC (1999). Council Directive 1999/31/EC of 26 April 1999 on the Landfill of Waste, 399L0031, Official Journal of the European Communities, 182, 1-19.

OJEC (2003). Council decision of 19 December 2002: establishing criteria and procedures for the acceptance of waste at landfills pursuant to article 16 of and Annex II to Directive 1999/31/EC, Official Journal of the European Communities, 11, 27-49.

Onay T.T., Pohland F.G. (1998). In Situ nitrogen management in controlled bioreactor landfills. Water Res. 32, 1383-1392.

Oonk H., Woelders H. (1999). Full-scale demonstration of treatment of mechanically separated organic residue in a bioreactor at VAM in Wijster. Waste Manage. Res. 17, 535-542.

Palmisano A.C., Barlaz M.A. (Eds.) (1996). Microbiology of Solid Waste. CRC Press, Florida, USA.

Parkin G.F., Owen W.F. (1986). Fundamentals of anaerobic digestion of wastewater sludges. J. Environ. Eng-ASCE. 112, 867-920.

Pfiffner A.O. (1988). Scientific and technical criteria for the final storage quality- introduction In "The Landfill, Reactor and Final Storage", p.p. 267, Swiss Workshop on Land Disposal of Solid Wastes, Gerzenzee, March 14-17, 1988, P. Baccini (Ed.), Springer-Verlag, Berlin. 
Pohland F.G. (1980). Leachate recycle as landfill management option. $J$. Environ. Eng.-ASCE. 106, 1057-1069.

Pohland F.G. (1996). Landfill Bioreactors: fundamentals and practice. Water Qual. Int. 9/10, 18-22.

Pohland F.G., Kim J.C. (1999). In Situ anaerobic treatment of leachate in landfill bioreactors. Water Sci. Technol. 40(8), 203-210.

Pouech P., Galtier L., Labbe H., Carles L., Gerbaux O. (1999). Leachate recirculation control in an extensive Bio-reactor landfill. In T.H. Christensen, R. Cossu, R. Stegmann (Eds.): Sardinia 1999 "Seventh International Waste Management and Landfill Symposium" October 1418, 1999, S. Margherita di Pula, Cagliari, Italy.

Price A.G., Barlaz M.A., Hater G.R. (2003). Nitrogen management in bioreactor landfills. Waste Manage. 23, 675-688.

Reinhart D.R., Townsend T.G. (1998). Landfill bioreactor design \& operation. Lewis Publishers, New York, USA.

Reinhart D.R., McCreanor P.T., Townsend T. (2002). The bioreactor landfill: Its status and future. Waste Manage. Res. 20, 172-186.

Reinhart D.R., Al-Yousfi B.A. (1996). The impact of leachate recirculation on municipal solid waste landfill operating characteristics. Waste Manage. Res. 14, 337-346.

Rosqvist N.H., Destouni G. (2000). Solute transport through preferential pathways in municipal solid waste. J. Contam. Hydrol. 46, 39-60.

Rosqvist N.H., Dollar L.H., Fourie A.B. (2005). Preferential flow in municipal solid waste and implications for long-term leachate quality: valuation of laboratory-scale experiments. Waste Manage. Res. 23, 367380 .

Sabbas T., Mostbauer P., Lechner P. (1999). Final Storage: Time scale, processes and factors beyond aftercare. In T.H. Christensen, R. Cossu, R. Stegmann (Eds.): Sardinia 1999 "Seventh International Waste Management and Landfill Symposium" October 14-18, 1999, S. Margherita di Pula, Cagliari, Italy.

Shearer B. (2001). Enhanced Biodegradation in Landfills. Master in Science Thesis, Virginia Polytechnic Institute and State University, USA. http://scholar.lib.vt.edu/theses/available/etd-05252001155108/unrestricted/1 thesis.pdf (Accessed December 2007) 
Silva W.L., Duarte V.L., Prasad S. (2004). Influence of inoculum on performance of anaerobic reactors for treating municipal solid waste. Bioresour. Technol. 94, 261-266.

Simon F.-G., Müller W.W. (2004). Standard and alternative landfill capping design in Germany. Environ. Sci. Policy 7, 277-290.

Tchobanoglous G., Kreith F. (2002). Handbook of solid waste management. McGraw-Hill publishers, New York, USA.

Townsend T.G., Miller W.L., Lee H.J., Earle J.F.K. (1996). Acceleration of landfill stabilization using leachate recycling. J. Environ. Eng-ASCE. 122, 263-268.

Townsend T.G., Miller W.L., Lee H.J., Earle J.F.K. (1995). Leachaterecycle infiltration ponds. J. Environ. Eng-ASCE. 121, 465-470.

Ulrich F., Kersten M., Wienberg R. (1988). Geochemical Processes in Landfills. In "The Landfill. Reactor and Final Storage", p.p. 39-81, Swiss Workshop on Land Disposal of Solid Wastes, March 14-17, Gerzenzee, 1988, P. Baccini (Ed.), Springer-Verlag, Berlin.

UN (2007). Environmental Indicators for waste.

http://unstats.un.org/unsd/ENVIRONMENT/wastetreatment.htm (Accessed December 2007).

USEPA (1999). U.S. Environmental Protection Agency: Decentralized system technology fact sheet - septage treatment/disposal.

http:/www.epa.gov/OWM/mtb/septage.pdf (Accessed January 2008)

USEPA (2003). U.S. Environmental Protection Agency: Bioreactors. http://www.epa.gov/epaoswer/non-hw/muncpl/landfill/bioreactor.htm (Accessed December 2007)

Veeken A., Kalyuzhnyi S., Scharff H., Hamelers B. (2000). Effect of pH and VFA on hydrolysis of organic solid waste. J. Environ. Eng-ASCE. 126, 1076-1081.

Vroon R., Oonk H., Van Marwijk W. (1999). A laboratory-scale exploration of the long-term behaviour of mechanically separated organic residue in a flushing bioreactor. Waste Manage. Res. 17, 527-534.

Wall D.K., Zeiss C. (1995). Municipal landfill biodegradation and settlement. J. Environ. Eng-ASCE. 121, 214-223.

Warith M. (2002). Bioreactor Landfills: experimental and field results. Waste Manage. 22, 7-17.

Warith M.A., Smolkin P.A., Caldwell J.G. (2001). Effect of leachate recirculation on enhancement of biological degradation of solid waste: 
case study. Pract. Period. Hazard. Toxic. Radioact. Waste Manage. 5, 4046.

WCED (1987). The World Commission on Environment and Development, Our Common Future. Oxford University Press, Oxford \& New York, USA.

Westlake K. (1995). Landfill waste pollution and control. Albion Publishing, Chichester, UK.

Westlake K. (1997). Sustainable landfill: possibility or pipe-dream? Waste Manag. Res. 15, 453-461.

WHO/UNICEF joint monitoring programme (2006). Meeting the MDG drinking water and sanitation target: the urban and the rural challenge of the decade. WHO LibraryCataloguing-in-Publication Data, Switzerland. http://www.wssinfo.org/pdf/JMP 06.pdf (Accessed January 2008)

Williams P.T. (1998). Waste Treatment and Disposal. Chapter 5, p.p. 223240. John Wiley \& Sons, Chichester, UK.

Yazdani R., Keiffer J., Sananikone K., Augenstein D. (2006). Full-scale bioreactor landfill for carbon sequestration and greenhouse emission control. http://www.co.yolo.ca.us/recycle/bioreactor.htm (Accessed December 2007)

Yuen S.T.S. (1999). Bioreactor Landfill promoted by leachate recirculationA full-scale study. PhD dissertation, Dept. of Civ. \& Environ. Eng., University of Melbourne, Australia.

Yuen S.T.S., Wang Q.J., Styles J.R. (2001). Water balance comparison between a dry and a wet landfill a full-scale experiment. J. Hydrol. 251: 29-48.

Zehnder J.A.B. (1988). Biology of Anaerobic Microorganisms. Wiley Series in Ecological and Applied Microbiology, U.S.A. 


\title{
2 \\ Chapter
}

\section{Achieving "Final Storage Quality" of MSW in pilot-scale bioreactor landfills}

The true worth of an experimenter consist in his pursuing not only what he seeks in his experiments, but also what he did not seek.

Claude Bernard (1813-1878)

\begin{abstract}
Entombed waste in current sanitary landfills will generate biogas and leachate when physical barriers fail in the future allowing the intrusion of moisture into the waste mass contradicting the precepts of the sustainability concept. Bioreactor landfills are suggested as a sustainable option to achieve Final Storage Quality (FSQ) status of waste residues; however, it is not clear what characteristics the residues should have in order to stop operation and aftercare monitoring schemes. An experiment was conducted to determine the feasibility to achieve FSQ status (WAC of the European Landfill Directive) of residues in a pilot scale bioreactor landfill. The results of the leaching test were very encouraging due to their proximity to achieve the proposed stringent FSQ criterion after two years of operation. Furthermore, residues have the same characteristics of alternative waste stabilisation parameters (low BMP, BOD/COD ratio, VS content, $\mathrm{SO}_{4}{ }^{2-} / \mathrm{Cl}^{-}$ratio) established by others researchers. Mass balances showed that the bioreactor
\end{abstract}

Published in Waste Management as: Achieving "Final Storage Quality" of municipal solid waste in pilot-scale bioreactor landfills. Valencia R., van der Zon W., Woelders H., Lubberding H.J., Gijzen H.J. (2008) in press. 
landfill simulator was capable to practically achieve biological stabilisation after 2 years of operation, while releasing approximately $45 \%$ of the total available (organic and inorganic) carbon and nitrogen into the liquid and gas phases.

\section{Introduction}

Municipal solid waste (MSW) disposed in landfills can be entombed for long-periods of time until physical barriers fail, allowing the intrusion of moisture. This would in turn trigger restrained physical-chemical and biological processes, causing pollution in the form of leachate and biogas (Allen, 2001; Tchobanoglous and Kreith, 2002). The chances of this event to happen increase with time especially after the landfill site has been closed and legally abandoned. This sharply contradicts with the basic understanding of sustainability, of not transferring economic and ecological burdens to future generations. Bioreactor landfills have been suggested to be a more sustainable alternative to conventional landfilling of MSW. Researchers have outlined the benefits of bioreactor landfills such as increased biogas production and recovery, shorter stabilisation periods, increased volume recovery and lower leachate strength (Reinhart and Townsend, 1998; Warith 2002). However, also constraints are mentioned, such as geo-technical stability, lack of process control, difficulties at field-scale operation and monitoring (Lee and Lee, 1994; Sheehan and McNelly, 2003). The fact that the bioreactor landfill approach is gaining a lot of attention, could suggest that the way normal sanitary landfills are currently operated will change in the near future. However, despite recent attempts by Barlaz et al. (2002) and François et al. (2006) to set numerical criteria that help operator and regulatory agencies to define waste stability, little information is available regarding the physical, chemical and biological characteristics of waste residues from bioreactor landfills. These characteristics should comply with the term Final Storage Quality (FSQ) of waste residues. However, FSQ of waste residues has not been well defined and there is no general consensus (Hjelmar and van der Sloot, 2003; Döberl et al., 2005). The earliest definition states that waste residues should have the same characteristics as those materials in their surrounding environment without the potential to produce pollution in the short, mid and long-term (Baccini, 1989). FSQ criteria should resemble the characteristics of inert waste as defined in the waste acceptance criteria (WAC) of Annex II of the Landfill Directive 
(CEC, 2003), because inert landfills face shorter or less stringent monitoring schemes according to the existing legislation. The objective of this study is to investigate the feasibility to achieve FSQ of waste residues using bioreactor landfills and the consequences on short and long-term emissions.

\section{Materials and Methods}

\subsection{Bioreactor Landfill simulators setup and operation}

Originally, two bioreactor landfill simulators were run, made from a 3 $\mathrm{cm}$ thick HDPE sewage pipe of $70 \mathrm{~cm}$ in diameter and $200 \mathrm{~cm}$ in height, hermetically sealed with HDPE lids and rubber rings attached at both ends. Schematic view and photographs of the simulators can be seen in Annex 1. The reactors were equipped at the top with a unidirectional dry gas meter (Meterfabriek Schlumberger) to record the volume of biogas produced and a water inlet for recirculation purposes. At the bottom, a water outlet was installed to allow the produced leachate flow into a reservoir for further recirculation using a high-speed pump (Lutz, model MA-II 3-12, Q $\max _{1}=1501$ $\min ^{-1}$ ). Three online thermocouple probes (Campbell Scientific, model 105T) were placed at 40, 100 and $160 \mathrm{~cm}$ from the top of each reactor, respectively. The internal temperature of the reactors was maintained around $30 \pm 4^{\circ} \mathrm{C}$ by means of an electrical blanket covered by fibre-wool with aluminium foil and wrapped in plastic. The reactors were filled with $500 \mathrm{~kg}$ (wet weight) of shredded (4 cm maximum size) MSW (moisture content $20 \%$ on wet weight basis). It is shredded to increase waste homogeneity, the surface area for biological degradation, the limitation of impermeable layers (i.e. plastics) and the improvement of water distribution (Yuen, 1999). The MSW was collected and characterized at the transfer station in Wijster, The Netherlands as shown in Table 1. The waste used in this experiment had a lower organic content and higher inorganic fractions (i.e. glass, plastics and inerts) compared to other similar studies (Šan and Onay, 2001; Sponza and A $\breve{g} d a g ̆$, 2004; He et al., 2005). However, it was similar to the waste used by Vroon et al, 1999. The waste was placed in layers of approximately $30 \mathrm{~cm}$ and compacted using a sledgehammer to an apparent density of $1040 \mathrm{~kg} \mathrm{~m}^{-3}$. 
Table 1. Composition of the municipal solid waste.

\begin{tabular}{lc}
\hline Component & Percentage (wet weight) \\
\hline Organic undefined & 33.2 \\
Paper \& cardboard & 15.2 \\
Plastics & 3.7 \\
Glass & 13.6 \\
Ferrous metals / non-ferrous metals & 0.6 \\
Leather/rubber & 0.2 \\
Wood & 2.5 \\
Inert $(>3.4 \mathrm{~mm})$ & 13.7 \\
Inert $(<3.4 \mathrm{~mm})$ & 15.2 \\
Textiles & 2.1 \\
\hline
\end{tabular}

Source: ESSENT Milieu 2004 at transfer station in Wijster, The Netherlands (Figures provided by H. Woelders)

Additionally, both reactors were seeded with approximately 200 litres of mature leachate in order to stimulate methanogenic and leaching conditions as suggested by Vroon et al. (1999) and Oonk and Woelders (1999). The characteristic of the seeding leachate are shown in Table 2. A fraction of the leachate produced was extracted and recycled back into each reactor, at different rates 3 times per week $\left( \pm 30 \mathrm{~L} \mathrm{week}^{-1}\right.$ for Reactor 1 and $\pm 15 \mathrm{~L}$ week $^{-1}$ for Reactor 2) aiming to maintain a continuous leachate flow within the reactor and at least a moisture content of $45 \%$ (field capacity) on wet weight basis. The leachate recycled was not amended (i.e. pH neutralisation, ammonium removal, etc.) at any stage of the experiment.

Table 2. Characteristics of the seeding mature leachate.

\begin{tabular}{lc}
\hline Element & Concentration* \\
\hline $\mathrm{pH}$ & 7.7 \\
$\mathrm{EC}$ & $14.3\left(\mathrm{mS} \mathrm{cm}^{-1}\right)$ \\
$\mathrm{BOD}$ & 650 \\
$\mathrm{COD}$ & 4240 \\
Ammonium & 610 \\
Nitrate & 100 \\
Chloride & 5480 \\
Sulphate & 210 \\
Bicarbonate & 7200 \\
\hline
\end{tabular}

*Units are in $\mathrm{mg} / \mathrm{L}$ unless specified otherwise, $\mathrm{pH}$ is unit less.

Source: ESSENT Milieu 2004 at transfer station in Wijster, The Netherlands (Figures provided by H. Woelders) 


\subsection{Analytical procedures}

Moisture and volatile solids content of the MSW were analysed according to Standard Methods (APHA, 2005). Additionally, a leaching test (NEN-EN 12457-4) was conducted in triplicate to determine the leaching potential of Chemical Oxygen Demand (COD); Biochemical Oxygen Demand (BOD); Total Organic Carbon (TOC); Total Kjeldahl Nitrogen (TKN); Ammonium $\left(\mathrm{NH}_{4}{ }^{+}\right)$selected ions $\left(\mathrm{Cl}^{-}, \mathrm{NO}_{3}{ }^{-}, \mathrm{PO}_{4}{ }^{3-}, \mathrm{SO}_{4}{ }^{2-}\right)$ and heavy metals $(\mathrm{Pb}, \mathrm{Ni}, \mathrm{Zn}, \mathrm{Cu}, \mathrm{Cd})$ of the solid waste according to European Standards (CEN, 2002). The elemental composition (CHNS) of the MSW was determined by flash combustion in a partial oxygen atmosphere using helium as carrier, at $1020{ }^{\circ} \mathrm{C}$ with a Thermo Quest EA 1110 Interscience elemental analyser. Leachate samples were analysed for $\mathrm{pH}$, temperature, conductivity and oxygen with portable meters WTW pH 340, LF 340 and Oxi 345 , respectively. COD, BOD, $\mathrm{TKN}, \mathrm{NH}_{4}{ }^{+}$, volatile fatty acids (VFA) (acetic, propionic, isobutyric, butyric and valeric) content of the leachate samples were analysed according to Standard Methods (APHA, 2005). TOC content of the leachate was determined using an OI Corporation TOC Analyser M-700. VFA were measured with a Chrompack CP9001 gas chromatograph, equipped with a FID and fitted with a Chrompack column (CP-FFAP-CB $25 \mathrm{~m}$ x $0.53 \mathrm{~mm}, 1 \mu \mathrm{m}$ ) using helium as carrier gas, coupled with a Shimadzu C-R5A Chromatopac integrator. Heavy metals content of the leachate were analysed with a Perkin Elmer Atomic Absorption Spectrometer 3110 flame detector. Ions in the leachate were analysed using an Ion Chromatography system DIONEX ICS-1000 attached with an automated sample injector DIONEX ASI-100. All liquid samples were filtered with glass fibre filters GF 52, Schleicher \& Schuell. Biogas composition $\left(\mathrm{CH}_{4}, \mathrm{CO}_{2}\right.$ and $\left.\mathrm{O}_{2}\right)$ was monitored using a Geotechnical Instruments GA25 portable gas extraction analyser. Gas samples were extracted by a gas sampling bulb (Chrompack), transferred to evacuated blood collection tubes (TERUMO, VenoJect, non-silicone coated) and analysed for $\mathrm{N}_{2} \mathrm{O}$ by gas chromatography. Hydrazine was measured using detector tubes (MSA, range 0.1-5 ppm) and a thumb-pump sampler (100cc sample volume stroke $\left.{ }^{-1}\right)$. 


\section{Results}

\subsection{Reactor behaviour}

Despite the fact that the initial setup included two bioreactor landfill simulators, only results of reactor 1 are reported here. Reactor 2 was stopped and emptied at day 500 when it was impossible to extract sufficient leachate for recirculation from the bottom of the reactor due to clogging, which caused an overflow of leachate at the upper part of the reactor. However, as reported before in Valencia et al. (2005) most of the physical-chemical and biological parameters of both reactors followed similar trends for the first 300 days of operation. Although no leaching tests were carried out to the residues of reactor 2 to evaluate their FSQ status, the carbon mass balance (88\% carbon recovery) was in close agreement with the biogas measured during the 500 days of operation.

\subsubsection{Physical-chemical parameters}

The temperature of the reactor was stable at about $30( \pm 4)^{\circ} \mathrm{C}$. Immediately after filling the reactor the $\mathrm{pH}$ was 5.5 (Fig. 1a) and after one day the $\mathrm{pH}$ increased to 6.3 due to the addition of methanogenic leachate of $\mathrm{pH}$ 7. Afterwards the $\mathrm{pH}$ decreased progressively from 6.2 to 5.5 during the first 200 days. After day 200, pH increased steadily up to 7.5 at day 430 and remained constant until the end of the experiment at day 730 . Conductivity increased from $20 \mathrm{mS} \mathrm{cm}^{-1}$ until values close to $35 \mathrm{mS} \mathrm{cm}^{-1}$ (Fig. 1a) due to the dissolution of salts into the leachate. The conductivity reached its lowest level $\left(12 \mathrm{mS} \mathrm{cm}^{-1}\right)$ at day 700 and seemed to increase towards the end of the experiment (day 730). The dissolved oxygen was depleted during the first two weeks of operation reaching values that fluctuated between 0 and $0.2 \mathrm{mgO}_{2} \mathrm{~L}^{-1}$ (Data not shown). 

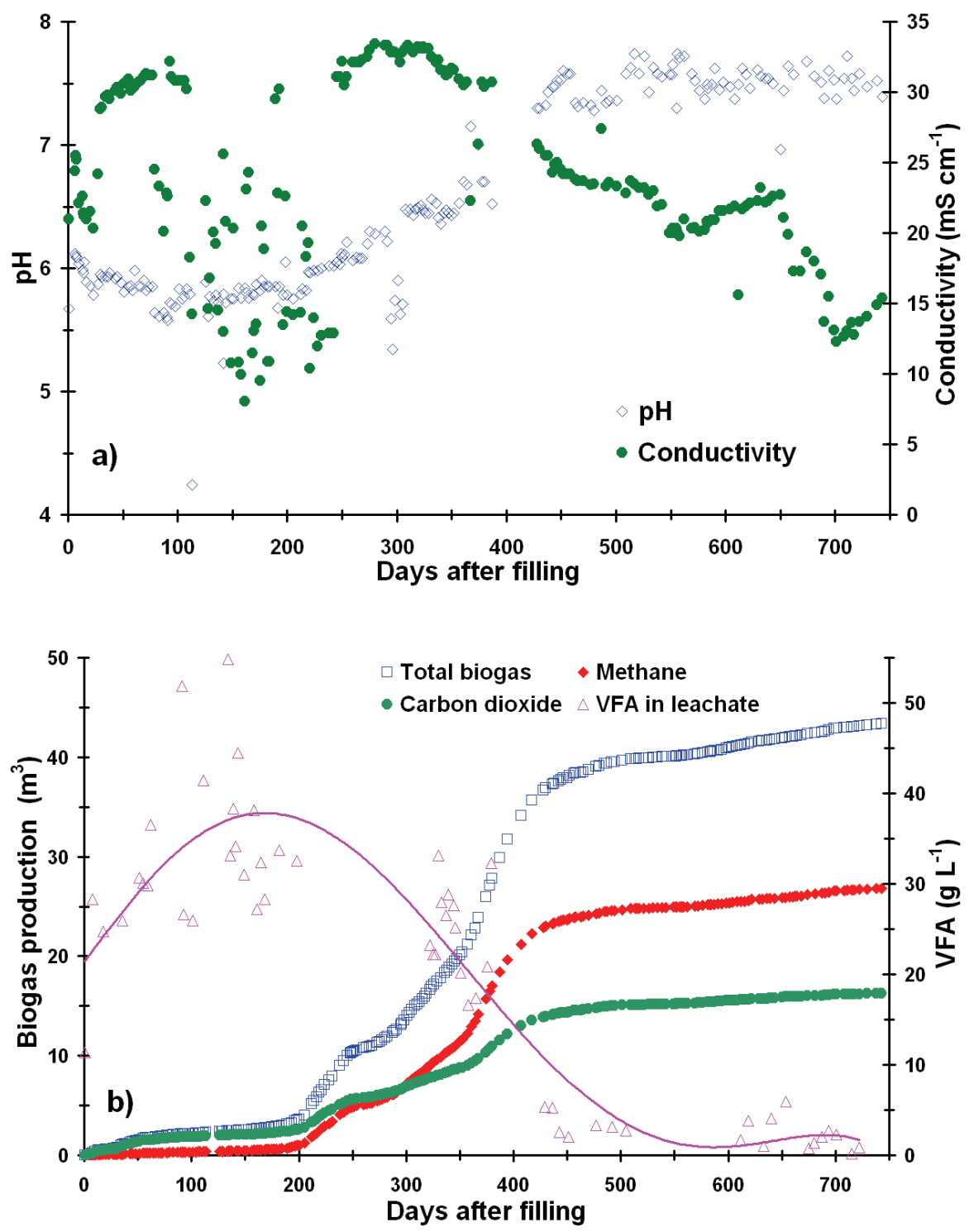

Figure 1. a) $\mathrm{pH}$ and conductivity of the leachate and b) cumulative production of biogas and VFA concentration in the Bioreactor Landfill simulator.

\subsubsection{Biological parameters}

Production of biogas started slowly during the first 200 days of operation, where approximately $3.6 \mathrm{~m}^{3}$ of biogas were produced, mainly composed of $\mathrm{CO}_{2}$ (Fig. 1b). However from day 200, the biogas production started to increase dramatically until day 500, in which period the biogas 
composition changed to $60 \% \mathrm{CH}_{4}-40 \% \mathrm{CO}_{2}$ by volume, a common biogas composition from biological reactors treating MSW. Although, the rate of biogas production decreased considerably from day 500, the biogas composition $\left(70 \% \mathrm{CH}_{4}-30 \% \mathrm{CO}_{2}\right.$ by volume) at this stage exceeded the typical biogas reported at diverse experiments with bioreactor landfill simulators, nevertheless biogas composition depends strongly on the $\mathrm{pH}$ of the system (Garcia-Heras, 2003). The VFA concentration (Fig. 1b) increased in the first 200 days due to accumulation of hydrolytic products and started to decrease afterwards due to conversion into biogas. The biogas yield $\left(0.46 \mathrm{~m}^{3}\right.$ of $\mathrm{CH}_{4} \mathrm{~kg}^{-1}$ of VS) observed in this experiment was similar or higher than those reported in the literature despite the lower organic content of the waste (Barlaz et al., 1989; Reinhart and Townsend, 1998; Šan and Onay, 2001; Tchobanoglous and Kreith, 2002; Sponza and Ağdağ, 2004; He et al., 2005; Davisson et al., 2007). The BOD/COD ratio, used to follow the biodegradability of the leachate (Fig. 2a) increased during the first 250 days up to values around 0.78 . The ratio decreased gradually during the following 400 days to 0.20 . An even sharper decrease was observed in the last 50 days of operation to values close to 0.10 .

Ammonia (Fig. 2b) increased sharply from around $1 \mathrm{~g} \mathrm{~L}^{-1}$ to $1.7 \mathrm{~g} \mathrm{~L}^{-1}$ in the first 20 days of operation and remained relatively constant for approximately 400 days. Although operation of the reactor continued as previously (but without analyses of samples), ammonia levels decreased drastically within the period between day 400 and 430 to values in the range of $0.85 \mathrm{~g} \mathrm{~L}^{-1}$ and remained constant the next 300 days. Finally, ammonia levels dropped in the last stage of the experiment to values around $0.65 \mathrm{~g} \mathrm{~L}^{-1}$. No $\mathrm{NO}_{3}^{-}, \mathrm{NO}_{2}^{-}$or $\mathrm{NH}_{3}$ were detected on incidental measurements before day 350. However, $\mathrm{NO}_{3}^{-}$was detected in minimal quantities $\left(2-5 \mathrm{mg} \mathrm{NO}{ }_{3}^{-} \mathrm{L}^{-1}\right)$ from day 350 up to an average of $30 \mathrm{mg} \mathrm{NO}_{3}{ }^{-} \mathrm{L}^{-1}$ at the end of the experiment (Data not shown). Since the total Kjeldahl nitrogen (TKN) was composed of $80-85 \%$ ammonia, the TKN trend was, therefore, to a large extent identical to the ammonia trend (Fig. 2b). Organic nitrogen, calculated by simple arithmetic subtraction, was low and showed a decreased trend towards the end of the experiment (Fig. 2b). 

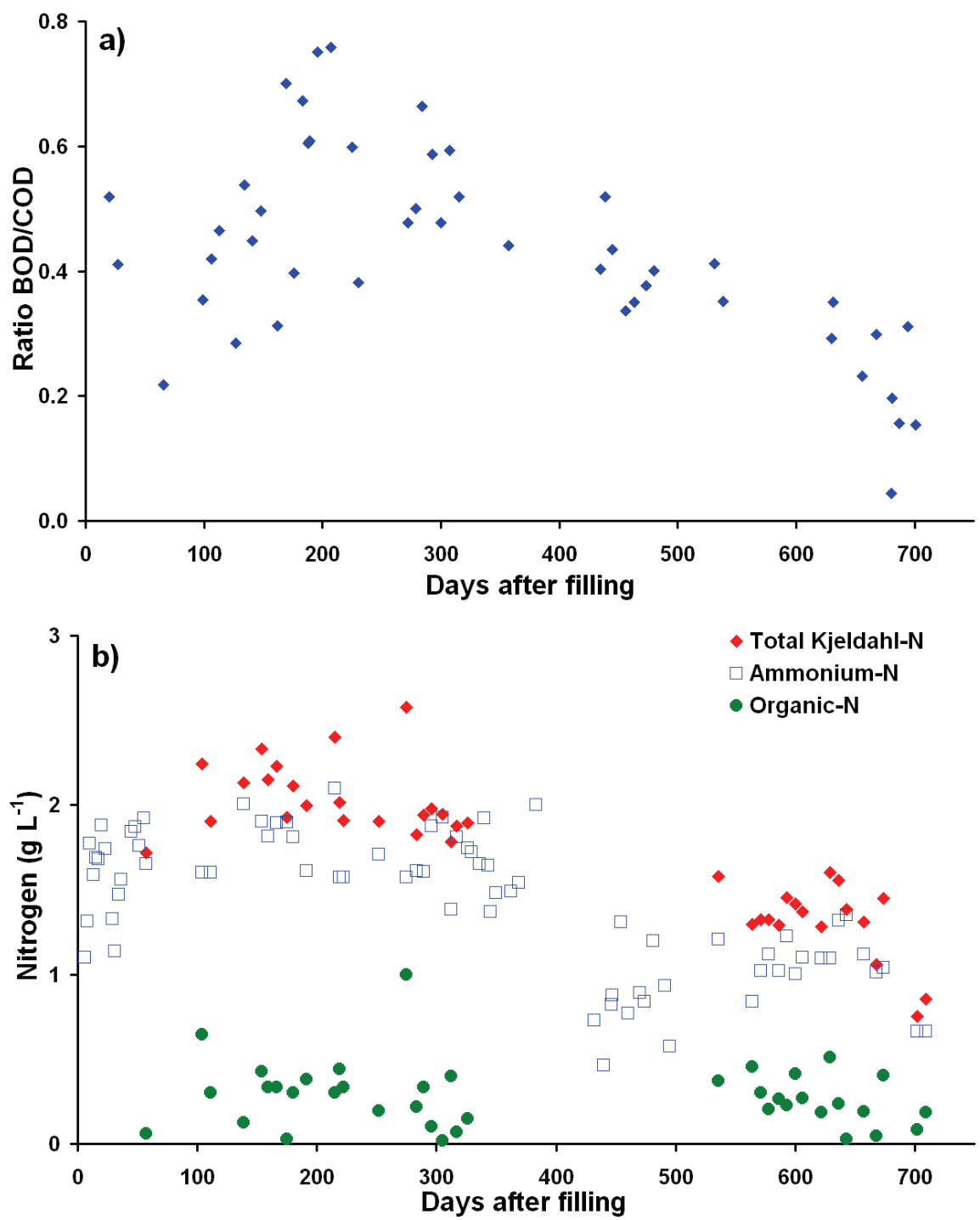

Figure 2. a) $\mathrm{BOD} / \mathrm{COD}$ ratio and b) nitrogen in the leachate from the Bioreactor Landfill simulator.

\subsection{Degree of waste stabilisation}

The initial and final characteristics of the waste in the simulator are shown in Table 3. Volatile solids (VS) content determined at the beginning and end of the experiment were approximately $38 \%$ and $24.4 \%$ on a dry weight basis. Accordingly, a reduction of the basic elements (C, N, H, S) content of the residues, $33 \%, 31 \%, 45 \%$ and $73 \%$, respectively was observed at the end of the experiment. 
Results of the leaching tests (Table 4) performed at the end of the experiment showed that the proposed criterion for FSQ was not achieved; nevertheless, the residues complied with the non-hazardous (low organic content) waste criteria of the annex II of the Landfill Directive (Francois et al., 2006), with the possibility to have a less stringent aftercare period. Other authors (Lo, 1996; Reinhart and Townsend, 1998) have determined specific parameters to define waste stability such as a low BMP $\left(<0.045 \mathrm{~m}^{3} \mathrm{CH}_{4} \mathrm{~kg}^{-1}\right.$ VS), BOD/COD ratio $(<0.10)$, VS content, a dark sludge-like appearance and low $(<0.1) \mathrm{SO}_{4}{ }^{2-} / \mathrm{Cl}^{-}$ratio. Similarly, heavy metals content were several folds lower than those stated in the regulation for exceptional quality compost of USEPA (Das et al., 2002). Apparently, shredding homogenised the MSW, allowing better distribution of the recycled leachate and therefore a homogenous MSW degradation throughout the simulator. This was confirmed by the minor variation on the leaching test results and elemental analyses, and the high biogas yield. In addition, the residue changed from a solid aggregate to a dark sludge-like material.

\section{Discussion}

\subsection{Reactor behaviour.}

Initially, biogas production was relatively low during the first 200 days presumably due a constant dissolution and accumulation of VFA, which kept $\mathrm{pH}$ values low (Fig. 1a), suggesting that acidogenic bacteria were governing the system (Veeken et al., 2000; Dinamarca et al., 2003). From day 200 a more acclimatised methanogenic bacteria population started to dominate the reactor converting VFA faster into biogas. This was in agreement with the depletion of VFA and increase of $\mathrm{pH}$ of the leachate during the same period. Removal of acidity from the reactor and the concomitant presence of dissolved salts (carbonates and phosphates) as expressed in the conductivity (Fig. 1a) increased the buffering capacity of the reactor. The highly variable period for conductivity values could be attributed to a constant precipitation and dissolution of carbonate minerals $\left(\mathrm{CaCO}_{3}\right)$ as $\mathrm{pH}$ values remained below 6 ; additionally conductivity values at the end of the experiment decreased probably due to physical and chemical processes (i.e. degassing and precipitation) occurring within the reactor 
(Thornton et al., 2000). This was consistent with lower salt concentrations measured in the last phase of the experiment.

Biogas production decreased considerably towards the end of the experiment, which was in agreement with the VFA depletion and low biodegradability ratio values (Figs $1 \mathrm{~b}$ and $2 \mathrm{a}$ ) observed during that period. Nevertheless, the ratio will never reach zero due to some slowly biodegradable organic matter present in the reactor, presumably lignin, humic and fulvic acids as suggested by Kjeldsen et al. (2002). The $\mathrm{BOD} / \mathrm{COD}$ values found at the beginning and at the end of the experiment corresponded to those found in leachates from unstable landfills (0-5 yr) and mature stable landfills (15-20 yr), respectively (Lo, 1996; Morris et al., 2003). The low VFA concentrations and BOD/COD ratio were an indication that most of the available organic matter has been converted into biogas and that biological stabilisation has been achieved.

The initial ammonia increase could be explained in fact by direct leaching of ammonia from the MSW, and the gradual ammonia increase in a later stage to protein degradation (Berge et al., 2005). Under strict anaerobic conditions no ammonia decrease is expected due to absence of ammonia removal mechanisms. However, after 400 days ammonia started to decrease, which could be explained by conversion of ammonia into nitrite/nitrate and ultimately into $\mathrm{N}_{2}$ by the nitrification and denitrification processes within the reactor caused by re-aeration of leachate during the recirculation process. These processes could have taken place throughout the entire experimental phase. Nevertheless, during the first 400 days, it was more likely that the supply rate of ammonia was higher than the transformation rate, while in this stage also anaerobic conditions prevailed. Conceivably, harsh environmental conditions (low pH, high VFA and conductivity) in place could have inhibited higher performance rates of the aforementioned processes. However as conditions improved, from day 400 onwards, $\mathrm{NH}_{4}{ }^{+}$levels dropped and $\mathrm{NO}_{3}{ }^{-}$, and $\mathrm{NH}_{3}$ were detected, providing support to the assumption of nitrification within the reactor. 


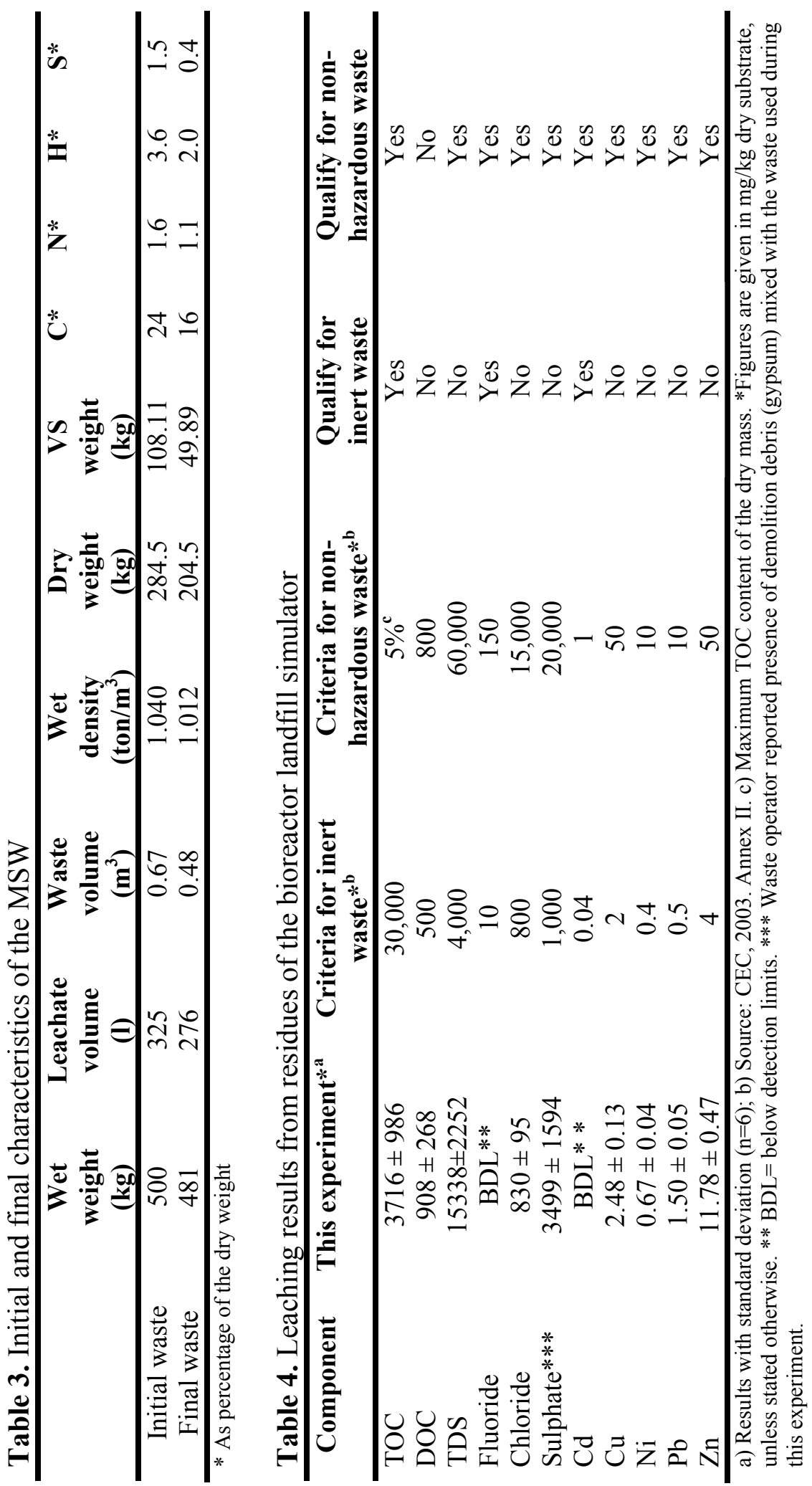




\subsection{Carbon and nitrogen mass balances}

The stoichiometric complete conversion of biodegradable solids to $\mathrm{CH}_{4}, \mathrm{CO}_{2}, \mathrm{NH}_{3}, \mathrm{H}_{2} \mathrm{~S}$ was calculated based on the formula proposed by Buswell and Mueller (1952) and the composition of the initial waste (Table 3 ); however, the oxygen content was derived from the average content found in the literature (Barlaz at al,, 1989; Tchobanoglous and Kreith, 2002):

$$
\begin{aligned}
& \mathbf{C}_{\mathbf{1 . 9 9 5}} \mathbf{H}_{3.58} \mathbf{O}_{1.256} \mathbf{N}_{\mathbf{0 . 1 1 5}} \mathbf{S}_{\mathbf{0 . 0 4 7}}+0.581 \mathbf{H}_{2} \mathbf{O} \Rightarrow 1.08 \mathbf{C H}_{\mathbf{4}}+0.92 \mathbf{C O}_{\mathbf{2}}+0.115 \mathbf{N H}_{3}+ \\
& 0.047 \mathbf{H}_{\mathbf{2}} \mathbf{S}
\end{aligned}
$$

( Eq. 1)

The measured carbon at the end of the experiment was responsible for $84 \%$ recovery of the initial waste (Fig. $3 \mathrm{a}$ ): $49 \%$ residual carbon, $21 \% \mathrm{CH}_{4}$, $13 \% \mathrm{CO}_{2}$ and $1 \%$ in the leachate. However based on Equation 1, the measured amount of $\mathrm{CH}_{4}(14.4 \mathrm{~kg})$ should lead to $(12.27 \mathrm{~kg})$ of $\mathrm{CO}_{2}$, correcting the $\mathrm{CO}_{2}$ fraction to $16 \%$ (Fig. 3a). In addition, the carbon balance was adjusted because of malfunctioning of the gas meter which was replaced by a precision dry gas meter and readings were extrapolated from previous and subsequent readings, these readings were considered as carbon losses and accounted for $1.36 \mathrm{~kg}$ of carbon (2\%). These corrections increased the carbon recovery up to $89 \%$, similarly to those balances proposed by Barlaz et al. (1989).

The unaccounted carbon fraction (11\%) might have deposited as carbonates (calcite, siderite, etc.) in the drainage layer (Rittmann et al., 2003; VanGulck and Rowe, 2004), since carbonate concentrations in solid, liquid or gas phases are dependant on the chemical equilibrium governed by the $\mathrm{pH}$ of the system (Garcia-Heras, 2003). Additionally, carbon could be lost as $\mathrm{CH}_{4}$ and $\mathrm{CO}_{2}$ escaping from the liquid phase during sampling and recycling of the leachate manually into the reactor. The carbon balance (Fig. 3a) revealed that most of the biodegradable carbon $( \pm 50 \%)$ was converted into biogas, whereas residues and leachate still contained some recalcitrant organic matter.

The measured nitrogen at the end of the experiment accounted for 53\% recovery: $49 \%$ residual nitrogen and $4 \%$ in the leachate (Fig. $3 \mathrm{~b}$ ). According to Equation 1, the reactor was initially loaded with $4.58 \mathrm{~kg}$ of 
nitrogen and $2.23 \mathrm{~kg}$ were accounted as residual nitrogen; therefore, $2.35 \mathrm{~kg}$ of nitrogen should have been transformed into ammonia gas or molecular nitrogen. Although no nitrogen gases determinations were carried out during this experiment, a corrected balance tried to account for some of these gases produced in the reactor, mainly as $\mathrm{N}_{2}$ and $\mathrm{NH}_{3} . \mathrm{NH}_{3}$ in the gas phase (Fig. $3 b$ ) was calculated based on $\mathrm{NH}_{3}$ volatilization rates related to $\mathrm{pH}$ values and accounted for $0.18 \mathrm{~kg}$ of $\mathrm{N}$, which is $2.2 \%$ of the total biogas produced. Similarly the $\mathrm{N}_{2}$ content $(0.87 \mathrm{~kg} \mathrm{~N})$ in the biogas was corrected using average concentrations of $\mathrm{N}_{2}$ in landfill gas $(2.5 \%)$ reported in literature (Tchobanoglous and Kreith, 2002), accounting for 19\% of the total nitrogen budget. Based on these assumptions the nitrogen recovery of the system was increased up to $77 \%$. The $\mathrm{N}_{2}$ source could be in situ nitrification of $\mathrm{NH}_{4}{ }^{+}$and successive denitrification of $\mathrm{NO}_{3}{ }^{-}$to $\mathrm{N}_{2}$ as reviewed by Berge et al. (2005). An alternative explanation could be the presence of Anammox bacteria in the system suggested by hydrazine, an intermediate product of Anammox metabolism (Van Niftrik et al., 2004), measured (incidentally: $n=6$ ) at the end of the experiment. The oxidised nitrogen forms $\left(\mathrm{NO}_{2}^{-}, \mathrm{NO}_{3}{ }^{-}\right)$could be produced by the introduction of oxygen during manual recirculation of leachate; this is in agreement with the reduction of $\mathrm{NH}_{4}{ }^{+}$observed at the end of the experiment (Fig. 2b). Microbial uptake of nitrogen could contribute to $\mathrm{NH}_{4}{ }^{+}$decrease during the exponential growth phase (Fig. 1b), but the nitrogen contained in the biomass was included in total nitrogen determinations from initial and final samples. Additionally, unaccounted nitrogen may be found in the drainage layer, precipitated as struvite (Kabdasli et al., 2000), or could be lost as $\mathrm{NO}_{\mathrm{x}}$ or $\mathrm{N}_{2} \mathrm{O}$ gases, due to partial denitrification, as detected on incidental measurements $\left(\mathrm{N}_{2} \mathrm{O}<10 \mathrm{ppm}\right)$ made on gas samples. The nitrogen balance (Fig. 3b) showed that approximately $47 \%$ of nitrogen can be transferred either into the liquid or gas phase contrary to the nitrogen balance proposed by Huber et al. (2004) for normal sanitary landfills where $4 \%$ leaves the system via the leachate and $96 \%$ remains in the system as residual nitrogen. 

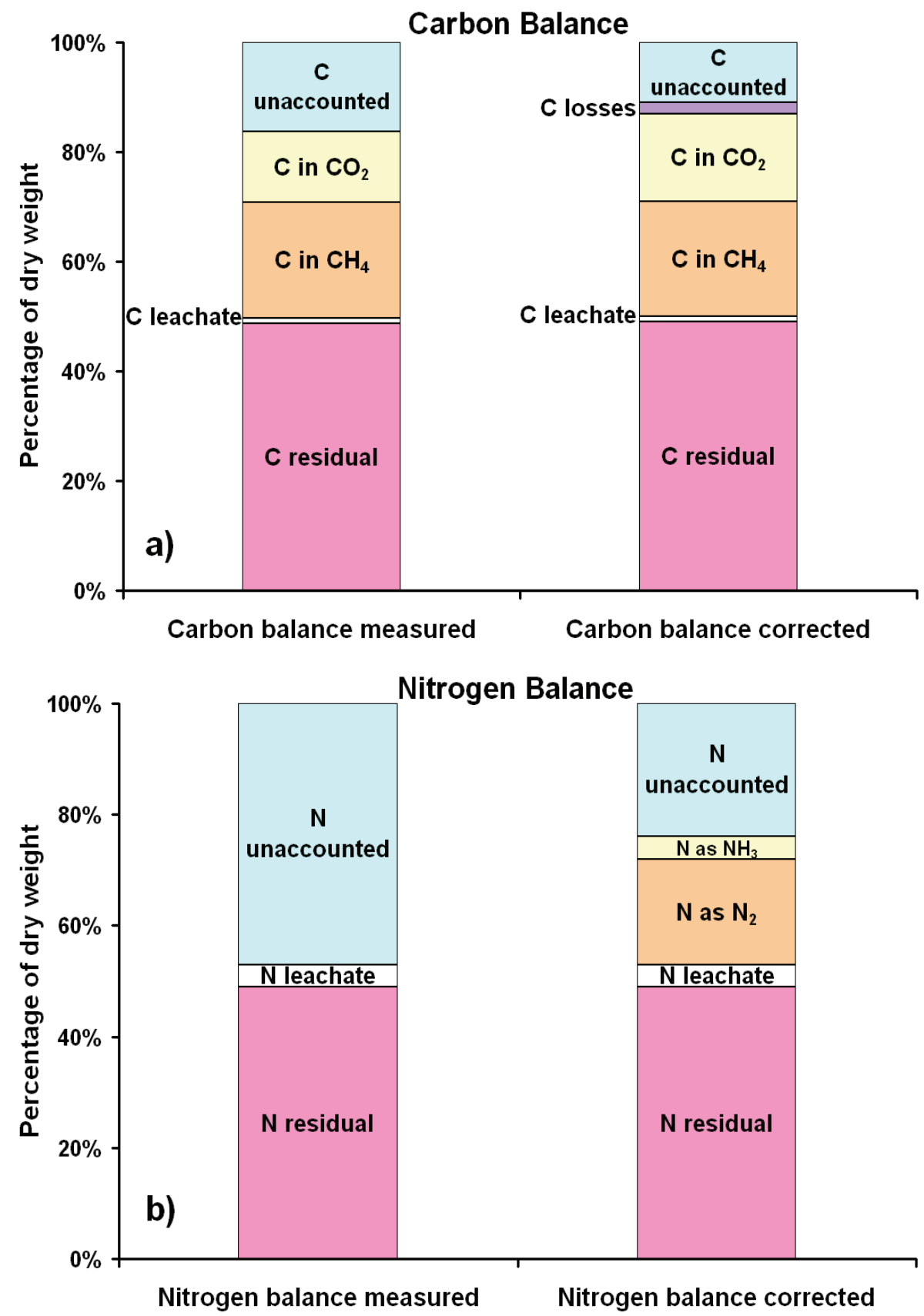

Figure 3. a) Carbon and b) nitrogen measured and corrected mass balances. 


\subsection{Final Storage Quality (FSQ)}

The results of the leaching test were very encouraging due to their proximity to achieve the proposed stringent criterion of FSQ after only two years of operation. Furthermore, residues complied with alternative waste stabilisation parameters established by other researches (Lo, 1996; Reinhart and Townsend, 1998).

The FSQ criterion was not completely achieved because the original salts and heavy metals content of the waste were above the maximum allowed in the WAC of the Landfill Directive (CEC, 2003). Furthermore, that there are no highly efficient removal mechanisms for heavy metals and salts in an anaerobic semi-close system. However, the availability of heavy metals and salts strongly depends on the MSW composition and the environmental conditions of the reactor. Since it is quite difficult to completely select the MSW to treat, the key to achieve FSQ must rely on the way the bioreactor landfill is operated. Nevertheless, operating a bioreactor landfill under strictly anaerobic conditions and without leachate treatment prior recirculation might not be the best approach to achieve chemically stable residues, despite the fact that biological stabilisation was achieved. In order to achieve an inert residual material, alternative modi operandi (i.e. aerobic, hybrid or flushing) that might change the form (complexes, precipitated, etc) in which heavy metals and salts are present in the residues and their availability to be leached must be implemented. The achievement of the FSQ status of waste residues meant that short- and long-term emissions will be below the legal permissible threshold (environmental standards). In addition, long lasting and costly monitoring aftercare programmes can be stopped allowing these sites to be both legally and safely abandoned or reclaimed for (residential and industrial) infrastructure development. The results of this experiment were similar to those reported in literature cited here, despite the fact that the MSW had lower organic content and that no amendments (i.e. $\mathrm{pH}$ neutralisation) were implemented to the recycled leachate. Additionally, results presented here provide a more complete picture of the biological, physical and chemical processes occurring in the bioreactor landfill simulator. Apparently, this is the first attempt to compare experimental results with the strict numeric criteria of the WAC from the Landfill Directive (CEC, 2003) for inert waste. 


\section{References}

Allen A. (2001). Containment Landfills: the myth of sustainability. Eng. Geol. 60, 3-19.

APHA (2005). Standard Methods for Water and Wastewater Examination, 21st ed. American Public Health Association, Washington, DC.

Baccini P. (Ed.) 1989. The landfill, Reactor and Final Storage, Lecture notes in earth Sciences, 20, Springer Verlag, Berlin, Germany.

Barlaz M.A., Ham R.K., Schaefer D.M. (1989). Mass-balance analysis of anaerobically decomposed refuse. J. Environ. Eng-ASCE. 115, 1088-1101.

Barlaz M.A., Rooker A.P., Kjeldsen P., Gabr M.A., Borden R.C. (2002). Critical evaluation of factors required to terminate the postclosure monitoring period at solid waste landfills. Environ. Sci. Technol. 36, 34573464.

Berge N.D., Reinhart D.R., Townsend T.G. (2005). The fate of nitrogen in bioreactor landfills. Crit. Rev. Env. Sci. Technol. 35, 365-399.

Buswell A.M., Mueller M.F. (1952). Mechanisms of methane fermentation. Ind. Eng. Chem. 44, 550-552.

CEC (2003). Council Decision 2003/33/EC of 19 December 2002, Establishing criteria and procedures for the acceptance of waste at landfills pursuant to Article 16 of and Annex II to Directive 1999/31/EC. Official Journal of the European Communities, 16.01.2003, L11/27- 49.

CEN (2002). "Compliance test for leaching of granular waste materials and sludges-Part 4", NEN-EN 12457-4:2002en, available in http://www2.nen.nl.

Das K.C., Smith M.C., Gattie K.D., Hale-Boothe D.D. (2002). Stability and quality of municipal solid waste compost from a landfill aerobic bioreduction process. Adv. Environ. Res. 6, 401-409.

Davisson A., Gruvberger C., Christensen T.H., Lund T.H., Cour J.J. (2007). Methane yield in source-sorted organic fraction of municipal solid waste. Waste Manage. 27, 406-414.

Dinamarca S., Aroca G., Chamy R., Guerrero L. (2003). The influence of pH in the hydrolytic stage of anaerobic digestion of the organic fraction of urban solid waste. Water Sci. Technol. 48(6), 249-254.

Döberl G., Huber R., Brunner P.H. (2005). Long-term emissions from landfills - Is "Final Storage Quality" within reach? In T.H. Christensen, R. Cossu, R. Stegmann (Eds.): Sardinia 2005 "Tenth International Waste 
Management and Landfill Symposium" October 4-9, 2005, S. Margherita di Pula, Cagliari, Italy.

Francois V., Feuillade G., Skhiri N., Lagier T., Matejka G. (2006). Indicating the parameters of the state of degradation of municipal solid waste. J. Hazard. Mater. 137, 1008-1015.

Garcia-Heras J.L. (2003). Reactor sizing, process kinetics, and modelling of anaerobic digestion of complex wastes. In J. Mata-Alvarez (Ed) (2003). Biomethanization of the organic fraction of municipal solid wastes. IWA publishing, London, U.K.

He P.-J., Shao L.-M., Qu X., Li G.-J., Lee D.-J. (2005). Effects of feed solutions on refuse hydrolysis and landfill leachate characteristics. Chemosphere 59, 837-844.

Hjelmar O., van der Sloot H. (2003). The EU Landfill Directive and the Council Decision on acceptance criteria for waste to be landfilled: overview and associated R\&D needs. In T.H. Christensen, R. Cossu, R. Stegmann (Eds.): Sardinia 2003 "Ninth International Waste Management and Landfill Symposium" October 6-10, 2003, S. Margherita di Pula, Cagliari, Italy.

Huber R., Fellner J., Döeberl G., Brunner P. (2004). Water flows of MSW landfills and implications for long-term emissions. J. Environ. Sci. Health. A39, 885-900.

Lo I.M.-C. (1996). Characteristics and treatments of leachates from domestic landfills. Environ. Int. 22, 433-442.

Kabdasli I., Tünay O., Öztürk I., Yilmaz S., Arikan (2000). Ammonia removal from young landfill leachate by magnesium ammonium phosphate precipitation and air stripping. Water Sci. Technol. 41(1), 237-240.

Kjeldsen P., Barlaz M.A., Rooker A.P., Baun A., Ledin A., Christensen T.H. (2002). Present and long-term composition of MSW landfill leachate: a review. Crit. Rev. Env. Sci. Technol. 32, 297-336.

Lee F.G., Lee A.J. (1994). Potential problems with MSW landfill leachate recirculation, letter to the editor. Solid Waste Technol. August.

Morris J.W.F., Vasuki N.C., Baker J.A., Pendleton C.H. (2003). Findings from long-term monitoring studies at MSW landfill facilities with leachate recirculation. Waste Manage. 23, 653-666.

Oonk H., Woelders H. (1999). Full-scale demonstration of treatment of mechanically separated organic residue in a bioreactor at VAM in Wijster. Waste Manage. Res. 17, 535-542. 
Reinhart D.R., Townsend T.G. (1998). Landfill Bioreactor Design \& Operation. Lewis Publisher, New York, USA.

Rittmann B.E., Banaszak J.E., Cooke A., Rowe R.K. (2003). Biogeochemical evaluation of mechanisms controlling $\mathrm{CaCO}_{3}(\mathrm{~s})$ precipitation in landfill leachate-collection systems. J. Environ. EngASCE. 129, 723-730.

Šan I., Onay T.T. (2001). Impact of various leachate recirculation regimes on municipal solid waste degradation. J. Hazard. Mater. B87, 259-271.

Sheehan B., McNelly J. (2003). Bioreactor and EPA proposal to deregulate landfills. J. Compos. Org. Recycl. 44, 60-63.

Sponza D.T., Ağdağ O.N. (2004). Impact of leachate recirculation and recirculation volume on stabilisation of municipal solid wastes in simulated anaerobic bioreactors. Process Biochem. 39, 2157-2165.

Tchobanoglous G., Kreith F. (2002). Handbook of solid waste management. McGraw-Hill publishers, New York, USA.

Thornton S.F., Tellam J.H., Lerner D.N. (2000). Attenuation of landfill leachate by UK Triassic sandstone aquifer materials 1, Fate of inorganic pollutants in laboratory columns. J. Contam. Hydrol. 43, 327-354

Valencia R., van der Zon W., Lubberding H.J., Gijzen H.J. (2005). Evolution and fate of nitrogen compounds in pilot scale Bioreactor Landfills. In T.H. Christensen, R. Cossu, R. Stegmann (Eds.): Sardinia 2005 "Tenth International Waste Management and Landfill Symposium" October 4-9, 2005, S. Margherita de Paula, Cagliari, Italy.

van Niftrik L.A., Fuerst J.A., Damste J.S.S., Kuenen J.G., Jetten M.S.M., Strous M. (2004). The anammoxosome: an intracytoplasmic compartment in anammox bacteria. FEMS Microbiol. Lett. 233, 7-13.

VanGulck J.F., Rowe R.K. (2004). Influence of landfill leachate suspended solids on clog (biorock) formation. Waste Manage. 24, 723-738.

Veeken A., Kalyuzhnyi S., Scharff H., Hamelers B. (2000). Effect of pH and VFA on hydrolysis of organic solid waste. J. Environ.Eng-ASCE. 126, 1076-1081.

Vroon R., Oonk H., van Marwijk W. (1999). A laboratory-scale exploration of the long-term behaviour of mechanically separated organic residue in a flushing bioreactor. Waste Manage. Res. 17, 527-534.

Yuen S.T.S. (1999). Bioreactor Landfill promoted by leachate recirculationA full-scale study. PhD dissertation, Dept. of Civ. \& Environ. Eng., University of Melbourne, Australia. 
Warith M. (2002). Bioreactor landfills: experimental and field results. Waste Manage. 22, 1-17. 
3

Chapter

\title{
Alternative treatment for septic tank sludge: Co-disposal with MSW in bioreactor landfill simulators
}

You cannot acquire experience by making experiments. You cannot create experience. You must undergo it.

Albert Camus (1913-1960)

\begin{abstract}
Co-disposal of septic tank sludge had a positive effect on the municipal solid waste (MSW) stabilisation process in bioreactor landfill simulators. Codisposal experiments were carried out using the bioreactor landfill approach aiming to solve the environmental problems caused by indiscriminate and inadequate disposal of MSW and especially of septic tank sludge. The simulator receiving septic tank sludge exhibited a 200 days shorter lag-phase as compared to the 350 days required by the control simulator to start the exponential biogas production. Additionally, the simulator with septic sludge apparently retained more moisture $(>60 \% \mathrm{w} / \mathrm{w})$, which enhanced the overall conversion of organic matter hence increasing the biogas production $(0.60$ $\mathrm{m}^{3}$ biogas $\mathrm{kg}^{-1} \mathrm{VS}$ converted) and removal efficiency of $60 \% \mathrm{VS}$ from the simulator. Alkaline $\mathrm{pH}$ values $(\mathrm{pH}>8.5)$ did not inhibit the biogas production; moreover it contributed to reduce partially the negative effects
\end{abstract}

Published in Journal of Environmental Management as: Alternative treatment for septic tank sludge: co-disposal with municipal solid waste in bioreactor landfill simulators. Valencia R., den Hamer D., Komboi J., Lubberding H.J., Gijzen H.J. (2008) in press. 
of $\mathrm{NH}_{4}^{+}\left(>2 \mathrm{~g} \mathrm{~L}^{-1}\right)$ due to $\mathrm{NH}_{3}$ volatilisation thus reducing the nitrogen content of the residues. Associated risks and hazards with septage disposal were practically eliminated as total coliform and faecal coliform content were reduced by $99 \%$ and $100 \%$, respectively at the end of the experiment. These results indicate that co-disposal has two direct benefits, including the safe and environmentally sound disposal of septic tank sludge and an improvement of the overall performance of the bioreactor landfill by increasing moisture retention and supplying a more acclimatised bacterial population.

\section{Introduction}

Urban and rural areas without sewage coverage rely heavily on on-site sanitation systems such as latrines and septic tanks for temporary treatment and disposal of human excreta (Chaggu et al., 2002). The objective of the septic tank is to provide initial treatment to household wastewater by intercepting and separating solid faecal matter from the liquid part. However, these systems, which require to be ideally emptied every 2-3 years, are not handled properly and usually after 5 to 10 years are overloaded reducing their treatment efficiency (NDUDP, 2001). Available methods of septic tank sludge treatment and disposal like composting, anaerobic digestion, chemical treatment are often not feasible for developing countries due to high handling and operational costs. Therefore, these rich moisture separated solids are often employed in agriculture or aquaculture or discharged indiscriminately into lanes, drainage ditches, sewer networks, onto open urban spaces, and into fresh and marine water bodies, causing serious environmental and health impacts (Bradley, 1981; Chen, 1988; NDUDP, 2001).

On the other hand, MSW stabilisation processes in sanitary landfills are restrained due to the lack of sufficient moisture, keeping the waste intact for long periods of time (Allen, 2001). A more sustainable approach is to operate the landfill as a bioreactor in order to enhance the stabilisation process of waste by addition of liquids (Valencia et al., 2008). However, the produced leachate is often not enough to cover the bioreactor landfill moisture requirements; therefore additional sources of moisture are constantly needed. Several investigations have been done with wastewater 
treatment plant (WWTP) sludge, rumen content from slaughterhouses, and dredging material (Reinhart and Townsend, 1988; Chan et al., 1999; Silva et al., 2004; Çinar et al., 2004). Co-digestion of WWTP sludge and the organic fraction of MSW (OFMSW) at mesophilic temperatures in a full-scale digestion plant improved the reactor performance as shown by the increased biogas production (Bolzonella et al, 2006). Studies carried out by Hartmann and Ahring (2005) on co-digestion of WWTP sludge, OFMSW and manure at thermophilic temperatures with liquid recirculation resulted in higher biogas production rates, slightly alkaline $\mathrm{pH}$ and gave no signs of inhibition by ammonia as was observed in the batch-type experiments. Neves et al. (2006) found that anaerobic co-digestion of coffee waste and sewage sludge enhanced the anaerobic digestion. However, coffee waste containing high levels of lignocellulose produced hydrolysis intermediates toxic for methane production. Despite legal and environmental constraints with the indiscriminate use of these materials, the result of these investigations revealed that co-disposal of these materials influences positively the waste stabilisation process. However, none of the previous experiments were done using septic tank sludge, which has different characteristics than regular sewage sludge (Harrison and Moffe, 2003). Research done by Leckie et al. (1979) and Leuschner (1989) reported that septic sludge (suggested as a poor inoculum source) influences negatively the process of MSW stabilisation by keeping $\mathrm{pH}$ at suboptimal levels and hence inhibiting the development of methanogenic bacteria. However, in the previous co-disposal experiments no recirculation of liquids was implemented and therefore no $\mathrm{pH}$ control measures could be applied. Since septic tank sludge is already separated from the liquid part, it should be safely disposed following the solid waste management pathway; co-disposal with MSW could provide a solution to the problem of extra moisture requirement in bioreactor landfills, while it would also provide an efficient and cost-effective disposal of septic sludge (Metcalf and Eddy, 1991). Therefore, the objective of this study is to evaluate the effect of septic tank sludge addition to the MSW stabilisation process in bioreactor landfills simulators. 


\section{Materials and Methods}

\subsection{Bioreactor landfill simulators setup and operation}

The bioreactor landfills were simulated by using PVC pipes, $23 \mathrm{~cm}$ in diameter and $100 \mathrm{~cm}$ in height, with a working volume of approximately $0.031 \mathrm{~m}^{3}$, hermetically sealed with PVC lids and rubber rings attached at both ends. Schematic views and photographs of the simulators can be seen in Annex 1. Reactors were equipped at the top with a unidirectional wet gas meter (Meterfabriek Schlumberger) to record the volume of biogas produced and a water inlet for recirculation purposes. At the bottom, a water outlet was installed to allow the produced leachate flow into a reservoir for further manual recirculation. Two online temperature sensors were placed at 35 and $75 \mathrm{~cm}$ from the top of the reactor, respectively. Internal temperatures were maintained around $30 \pm 1^{\circ} \mathrm{C}$ by means of an electrical blanket covered by fibre-wool with aluminium foil and wrapped in plastic. Both reactors were filled with shredded MSW collected and characterised at the transfer station in Wijster, The Netherlands, as shown in Table 1. The control reactor (called MSW) was filled with only $30 \mathrm{~kg}$ of MSW (wet weight) and the second reactor $(\mathrm{MSW}+\mathrm{S})$ was filled with a mechanically homogenised mixture of $25 \mathrm{~kg}$ MSW and $8.5 \mathrm{~kg}$ (wet weight) of septic sludge, collected from a septic tank receiving only human waste at a farmhouse in the outskirts of Delft, The Netherlands. The waste was placed in layers of approximately $30 \mathrm{~cm}$ and compacted using a sledgehammer to an apparent density of 967 and $1080 \mathrm{~kg}$ $\mathrm{m}^{-3}$ for the control reactor and the homogenised mixture, respectively. Additionally, 7 litres of warm $\left(30^{\circ} \mathrm{C}\right)$ tap-water were added to each reactor during the filling procedure in order to stimulate leaching conditions. The leachate produced was recycled manually to the top of the reactor 3 times per week $\left( \pm 1 \mathrm{~L}\right.$ week $\left.^{-1}\right)$ aiming to maintain the reactors at field capacity (approximately at $45 \%$ moisture content, on wet weight basis). 
Table 1. Composition of the municipal solid waste.

\begin{tabular}{lc}
\hline Component & Percentage (wet weight) \\
\hline Organic undefined & 32.5 \\
Paper \& cardboard & 16.5 \\
Plastics & 3.5 \\
Glass & 12.9 \\
Ferrous metals / non-ferrous metals & 0.6 \\
Leather/rubber & 0.2 \\
Wood & 2.2 \\
Inert $(>3.4 \mathrm{~mm})$ & 13 \\
Inert $(<3.4 \mathrm{~mm})$ & 16.5 \\
Textiles & 2.1 \\
\hline
\end{tabular}

Source: ESSENT Milieu 2005 at transfer station in Wijster, The Netherlands (Provided by H. Woelders)

\subsection{Analytical procedures}

Moisture and volatile solids content of the MSW were analysed according to Standard Methods (APHA, 2005). The elemental composition $(\mathrm{C}, \mathrm{H}, \mathrm{N}, \mathrm{S})$ of the MSW and mixture of $\mathrm{MSW}+\mathrm{S}$ were determined by flash combustion in a partial oxygen atmosphere using helium as carrier, at $1020^{\circ} \mathrm{C}$ with a Thermo Quest EA 1110 Interscience elemental analyser. Leachate samples were analysed for $\mathrm{pH}$, electrical conductivity (EC) and oxygen with portable meters WTW pH340, LF340 and Oxi345, respectively. Chemical oxygen demand (COD), biochemical oxygen demand (BOD) and $\mathrm{NH}_{4}{ }^{+}$were analysed according to Standard Methods (APHA, 2005). Total organic carbon (TOC) was determined using an OI Corporation TOC Analyser M-700. All liquid samples were filtered with glass fibre filters GF 52, Schleicher \& Schuell. Extraction and preparation techniques for microbial analyses of MSW and mixtures of MSW and septic tank sludge (STS) were performed following the procedures described by Vanderzant and Splittstoesser (1992). Microbial determinations were done using the Chromocult $^{\circledR}$ coliform agar technique (MERCK) as previously reported by Finney et al. (2003). Gas production was measured using unidirectional precision wet gas meters (Meterfabriek Schlumberger). All samples taken from the simulators were analysed in duplicate (BOD, $\mathrm{NH}_{4}^{+}$) or triplicate (COD, TOC), results reported in the graphs are the average of these samples. No error bars were added to the graphs because the standard deviation calculated was minimal to be noticeable as error bars. 


\section{Results}

\subsection{Behaviour of the reactors}

\subsubsection{Physical-chemical parameters}

In both reactors the $\mathrm{pH}$ of the leachate (Fig. 1a) started at values around 5.2, and increased in the first week of operation to values around 7 and 6.5 for reactor with $\mathrm{MSW}$ and $\mathrm{MSW}+\mathrm{S}$, respectively. $\mathrm{pH}$ values of both reactors decreased slightly below 6 after 3 weeks of operation. Contrary to the $\mathrm{pH}$ values of the reactor with MSW, which remained constant at values slightly below 6 throughout the entire experiment, the $\mathrm{pH}$ of the reactor with $\mathrm{MSW}+\mathrm{S}$ increased gradually from day 100 reaching values close to 7 at day 300. An even sharper increase was observed from day 300 up to day 400 , reaching values around 9.5, which decreased to 8.6 towards the end of the experiment at day 450. Electrical conductivity (EC) of the leachate (Fig. 1a) of the reactor with MSW increased from $25 \mathrm{mS} \mathrm{cm}^{-1}$ up to $37 \mathrm{mS} \mathrm{cm}^{-1}$ in the first 50 days, then sharply decreased to values close to $30 \mathrm{mS} \mathrm{cm}^{-1}$ and remained constant throughout the experiment. In contrast, EC of the reactor with $\mathrm{MSW}+\mathrm{S}$ increased gradually from $20 \mathrm{mS} \mathrm{cm}^{-1}$ to $40 \mathrm{mS} \mathrm{cm}^{-1}$ during 350 days, but EC deceased sharply $\left(25 \mathrm{mS} \mathrm{cm}^{-1}\right)$ towards the end of the experiment at day 450. Dissolved oxygen was depleted in both reactors from $4 \mathrm{mg} \mathrm{O} \mathrm{O}^{-1}$ within 3 weeks of operation and afterwards the oxygen concentrations fluctuated between 0 and $0.2 \mathrm{mg} \mathrm{O}_{2} \mathrm{~L}^{-1}$ (Data not shown). 

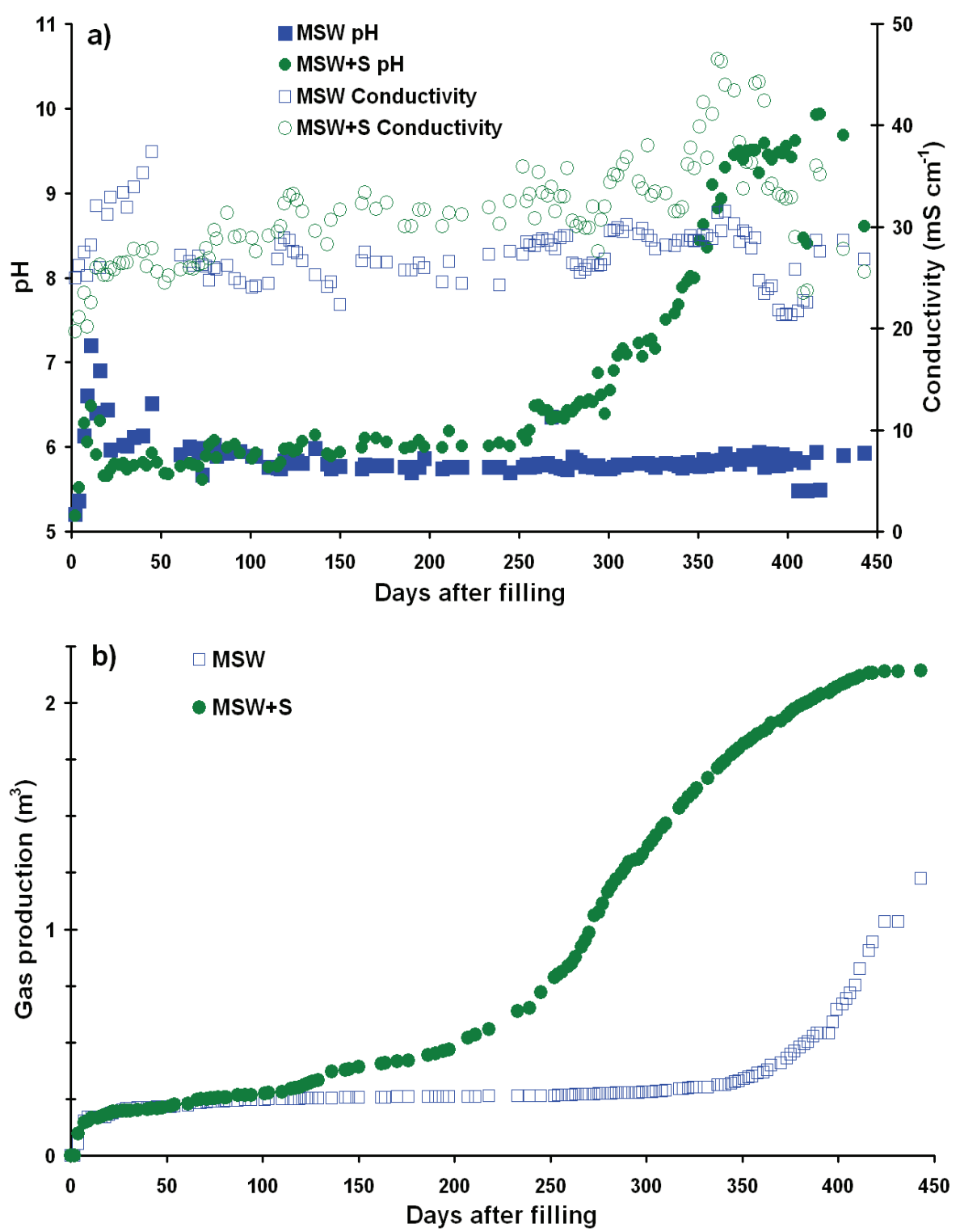

Figure 1. a) $\mathrm{pH}$ and $\mathrm{EC}$ of the leachate and b) cumulative biogas production of the bioreactor landfill simulators

\subsubsection{Biological parameters}

Biogas production (Fig. 1b) in both reactors increased in a similar way during the first 100 days $\left( \pm 0.25 \mathrm{~m}^{3}\right)$. However, the reactor with $\mathrm{MSW}+\mathrm{S}$ started to produce considerably more biogas after 100 days reaching approximately $2.2 \mathrm{~m}^{3}$ after 450 days of operation. In contrast, biogas 
production at reactor with MSW started to increase after day 350 producing $1.25 \mathrm{~m}^{3}$ towards the end of the experiment. Biogas yields observed were

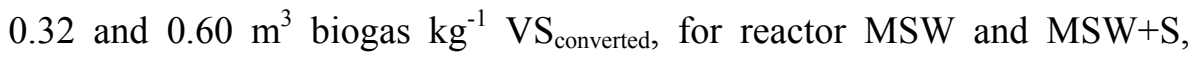
respectively. These yields were within the higher ranges reported in literature (Bolzonella et al., 2006; Chan et al., 1999; Hartmann and Ahring, 2005; Neves et al., 2006)

The biodegradability of the leachate was followed by means of the $\mathrm{BOD} / \mathrm{COD}$ ratio (Fig. 2a), which started at 0.6 and 0.4 , followed by an increase up to 0.8 and 0.65 during the first 50 days of operation for reactor MSW and MSW+S, respectively. The values of the BOD/COD ratio of reactor with only MSW remained relatively constant in the range between 0.6 and 0.65 throughout the entire experiment (values between days 50 and 250 not available). In contrast, $\mathrm{BOD} / \mathrm{COD}$ values in the reactor with $\mathrm{MSW}+\mathrm{S}$ decreased progressively from 0.6 at day 300 to around 0.2 at day 450 .

The TOC of both reactors (Fig. 2b) increased from 20 and $15 \mathrm{~g}$ TOC $\mathrm{L}^{-1}$ to $30 \mathrm{~g}$ TOC $\mathrm{L}^{-1}$ during the first 50 days of operation. TOC values of the reactor with MSW decreased to values around $20 \mathrm{~g}_{\text {TOC L }}^{-1}$ after 100 days and remained constant until day 300, decreasing further reaching values around $10 \mathrm{~g} \mathrm{TOC} \mathrm{L}^{-1}$ at the end of the experiment. The reactor with MSW+S followed a similar decreasing trend; however, the final decrease was steeper occurring after day 250 and reached values close to $2 \mathrm{~g} \mathrm{TOC} \mathrm{L}^{-1}$ at day 450 . 

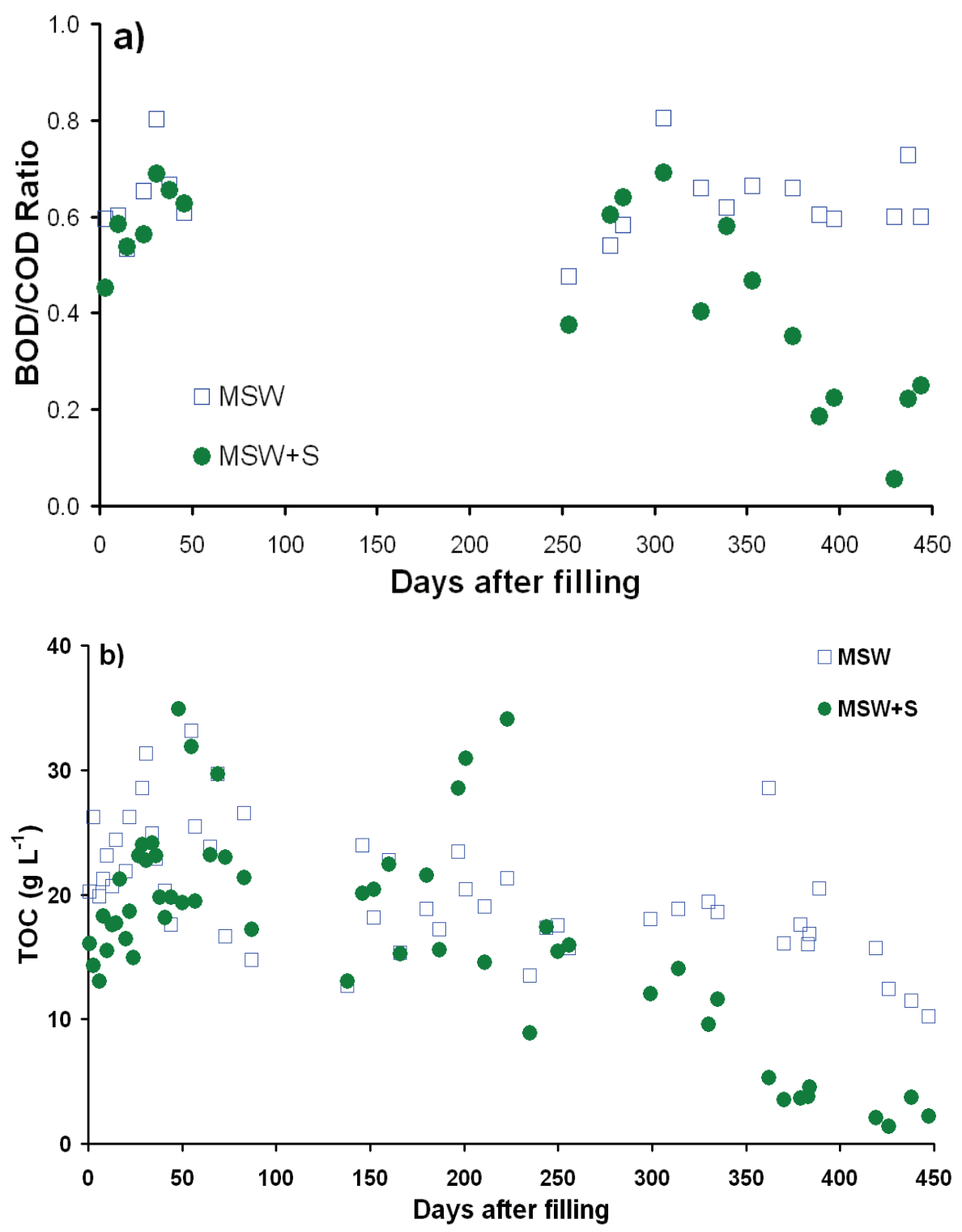

Figure 2. a) $\mathrm{BOD} / \mathrm{COD}$ ratio of the leachate and b) TOC of the leachate from the bioreactor landfill simulators

$\mathrm{NH}_{4}{ }^{+}$in the leachate (Fig. 3) at both reactors increased gradually from 0.5 up to $1.5 \mathrm{~g} \mathrm{~L}^{-1}$ during the first 50 days of operation. After 150 days there was a second increase up to $2-2.5 \mathrm{~g} \mathrm{NH}_{4}{ }^{+} \mathrm{L}^{-1}$, respectively for the MSW and MSW+S. Contrary to the $\mathrm{NH}_{4}^{+}$concentration of the MSW reactor that remained constant until the end of the experiment, a sharp decrease of the $\mathrm{NH}_{4}{ }^{+}$concentration on MSW+S reactor was observed after day 350. 
However, the $\mathrm{NH}_{4}{ }^{+}$concentration remained around $0.5 \mathrm{~g} \mathrm{~L}^{-1}$ towards the end of the experiment.

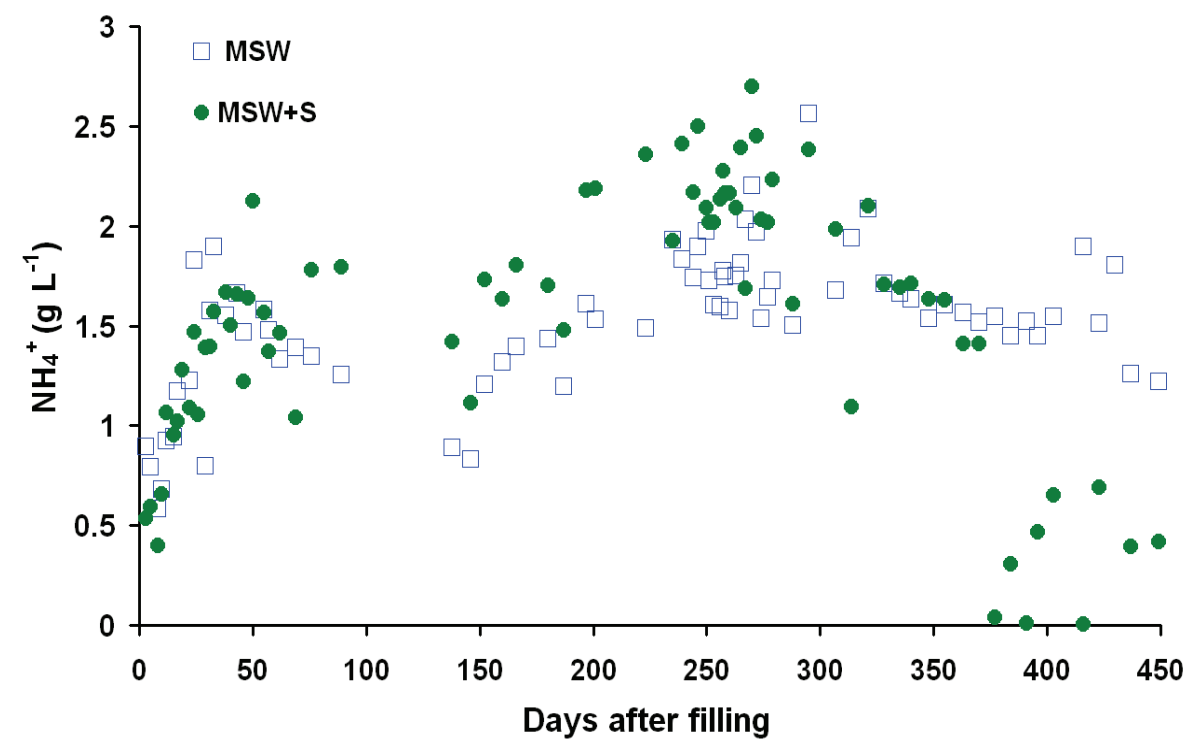

Figure 3. Ammonium in the leachate of the bioreactor landfill simulator

\subsection{Degree of waste stabilisation}

The physical characteristics and elemental (CNHS) content of the initial MSW, MSW+S mixture and residues are shown in table 2.

The stoichiometric complete conversion of biodegradable solids to $\mathrm{CH}_{4}, \mathrm{CO}_{2}, \mathrm{NH}_{3}$, and $\mathrm{H}_{2} \mathrm{~S}$ was calculated based on the formula (1) proposed by Buswell and Mueller (1952) and the results of Table 2; however, the oxygen content was derived from the average content found in literature (Barlaz et al., 1989; Tchobanoglous and Kreith, 2002).

$$
\begin{aligned}
& \mathbf{C}_{. \mathbf{v}} \mathbf{H}_{\mathbf{w}} \mathbf{O}_{\mathbf{x}} \mathbf{N}_{\mathbf{y}} \mathbf{S}_{\mathbf{z}}+\left[v-\frac{w}{4}-\frac{x}{2}+\frac{3 y}{8}+\frac{z}{2}\right] \mathbf{H}_{2} \mathbf{O} \Rightarrow\left[\frac{v}{2}+\frac{w}{8}-\frac{x}{4}-\frac{3 y}{8}-\frac{z}{2}\right] \mathbf{C H}_{4} \\
& +\left[\frac{v}{2}-\frac{w}{8}+\frac{x}{4}+\frac{3 y}{8}+\frac{z}{2}\right] \mathbf{C O}_{2}+\mathrm{y} \mathbf{N H}_{3}+\mathrm{z} \mathbf{H}_{2} \mathbf{S}
\end{aligned}
$$

The mass balances revealed, based on Equation 1 and the amount of dry matter converted $(\mathrm{MSW}=1.65 \mathrm{~kg}$ and $\mathrm{MSW}+\mathrm{S}=2.63 \mathrm{~kg})$, that the 
reactors must have produced around 1.45 and $2.38 \mathrm{~m}^{3}$ of biogas, whereas only 1.12 and $2.15 \mathrm{~m}^{3}$ of biogas were measured for reactors with MSW and $\mathrm{MSW}+\mathrm{S}$ respectively, during the entire length of the experiment.

Table 2. Physical properties and elemental analyses of initial and final content

\begin{tabular}{lccccccc}
\hline & $\begin{array}{c}\text { Dry } \\
\text { weight } \\
(\mathbf{k g})\end{array}$ & $\begin{array}{c}\text { Moisture } \\
\text { content } \\
(\%)\end{array}$ & $\begin{array}{c}\text { VS } \\
\text { content } \\
(\%)\end{array}$ & $\mathbf{C}^{*}$ & $\mathbf{N}^{*}$ & $\mathbf{H}^{*}$ & $\mathbf{S}^{*}$ \\
\hline Initial MSW & 17.5 & 43.5 & 38.5 & 23.96 & 1.63 & 3.21 & 1.49 \\
Final MSW & 15.9 & 53.5 & 21.0 & 17.78 & 1.31 & 2.18 & 0.68 \\
Initial MSW+S** & 12.7 & 61.9 & 41.6 & 25.73 & 1.42 & 3.69 & 1.54 \\
Final MSW+S** & 10.0 & 62.3 & 17.0 & 18.00 & 1.25 & 2.37 & 0.26 \\
\hline
\end{tabular}

*Elemental analyses figures reported as percentage of dry weight

** Mixtures based on organic matter content

\subsection{Pathogen reduction from the residues of the simulators}

The total initial content of total coliform content (Fig. 4a) of both reactors started at $3 \cdot 10^{11} \mathrm{CFU}$ reactor ${ }^{-1}$ and decreased to levels around $3 \cdot 10^{9}$ CFU reactor ${ }^{-1}$ at day 450 . Faecal coliforms (Fig. $4 \mathrm{a}$ ) of both reactors started at $3 \cdot 10^{10} \mathrm{CFU}$ reactor ${ }^{-1}$ and were not detected at the end of the experiment at day 450 .

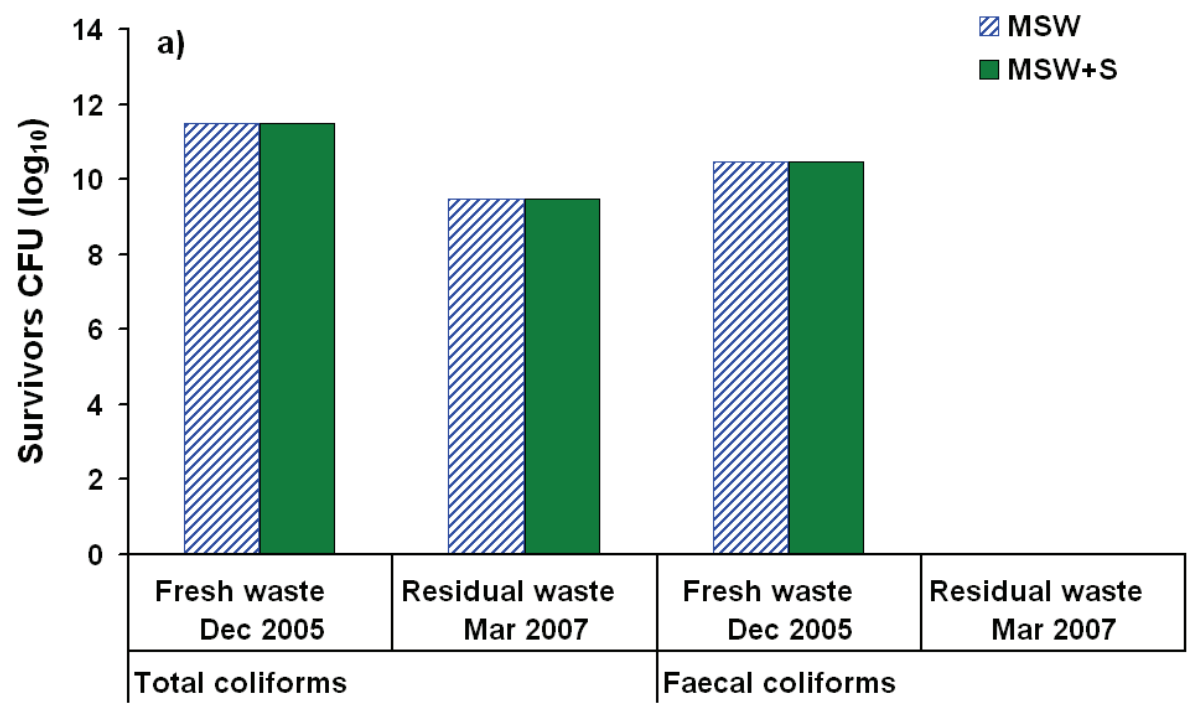




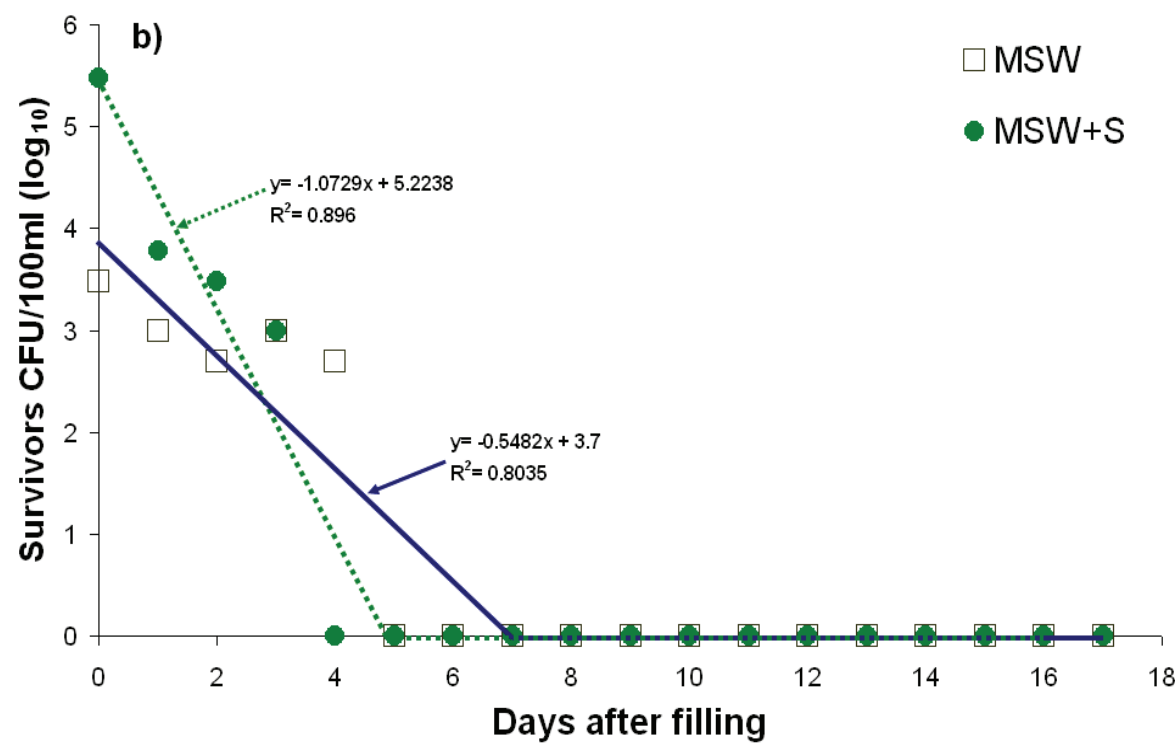

Figure 4. a) Total and faecal coliform content of fresh and residual waste and b) faecal coliforms in the leachate of the bioreactor landfill simulators

Despite the fact that faecal coliform content in the leachate of both reactors differed considerably at the start, after 5 days no faecal coliforms could be detected anymore (Fig. 4b).

\section{Discussion}

\subsection{Reactor performance}

The initial increase of $\mathrm{pH}$ could be attributed to an increase of the buffer capacity of the leachate caused by the dissolution of salts, such as $\mathrm{NH}_{4}{ }^{+}$, contained in the waste into the leachate as observed by the increase of EC of the leachate (Fig. 1a). However, due to enhanced organic matter hydrolysis, accumulation of hydrolytic products (VFA) subsequently increased the acidity within both reactors hence reducing $\mathrm{pH}$. The $\mathrm{pH}$ of the reactor treating only MSW was similar as in previous experiments (Valencia et al., 2005), suggesting that without control measures such as leachate buffering (Valencia et al., 2008) or seeding as reported here, bacterial populations will experience long lag-phases before adapting to the surrounding environment. 
Apparently, the more acclimatised hydrolytic/methanogenic bacteria coming from the septic sludge adapted in a faster way to the environmental conditions of the reactor with $\mathrm{MSW}+\mathrm{S}$. This in turn help to transform the available hydrolytic products faster into biogas (Fig. 1b), which led to an increase of $\mathrm{pH}$ values up to neutral ranges and even to alkaline ranges. These alkaline $\mathrm{pH}$ levels have been reported before for reactors treating wastes and sludge (Chan et al., 1999). The alkaline $\mathrm{pH}$ values of the reactor with $\mathrm{MSW}+\mathrm{S}$ could be attributed to an excessive production $\mathrm{NH}_{4}^{+}$and dissolution of ammonia salts into the leachate and the concomitant shift of the carbonate equilibrium due to the high $\mathrm{pH}$ values as observed by the increase of leachate EC from day 250 until day 380. Calculations revealed that the absolute difference in $\mathrm{NH}_{4}^{+}$concentration between both reactors corresponded to $6.75 \mathrm{mS} \mathrm{cm}^{-1}$, which was $95 \%$ of the EC difference between day 250 and day 450. However, $\mathrm{NH}_{4}{ }^{+}$concentration in the leachate decreased significantly towards the end of the experiment since at those high $\mathrm{pH}$ levels $\mathrm{NH}_{4}^{+}$is lost due to volatilisation of $\mathrm{NH}_{3}$ (Cheung et al., 1997); this was inline with the observed decrease of leachate EC during the same period.

According to biogas production rates, the high $\mathrm{pH}$ did not have a negative impact on the overall performance of the reactor. The high alkalinity of the reactor contributed to neutralise the reactor $\mathrm{pH}$ thus reducing the negative effect of excessive VFA production (He et al., 2005). Correspondingly, Kadam and Boone (1996) reported that specific species of methanogens are able to adjust their internal $\mathrm{pH}$ as external $\mathrm{pH}$ levels are increased (i.e. by dissolution of $\mathrm{NH}_{4}^{+}$). This in turn suggests that higher the $\mathrm{pH}$ less the inhibitory $\mathrm{NH}_{4}^{+}$effect for methanogens is. Based on the results from Table 2 and Equation 1, the biogas recovery was approximately 77\% and $90 \%$ for reactors $\mathrm{MSW}$ and $\mathrm{MSW}+\mathrm{S}$, respectively, similar to those recovery rates reported by Barlaz et al., 1989. The difference in biogas production between both reactors could be explained by the rapid consumption and transformation of biodegradable compounds and organic carbon which were visible by the decrease of the BOD/COD ratio and TOC, Figs. $2 a$ and $2 b$, respectively. Presumably the reactor with only MSW will achieve the same amount of biogas produced by the reactor with $\mathrm{MSW}+\mathrm{S}$, however the inherent bacterial population has to adapt to the reactor's environment. Despite the sub-optimal $\mathrm{pH}$ values measured at the bottom of 
the reactor, the methanogenic bacterial population at the top and middle of the reactor may have started to adapt from day 350 onwards as seen by the late but steady biogas production increase (Fig. 1b) and reduction of TOC (Fig. 2b) in the leachate during the same period.

Septic tank sludge contributed to $3.34 \%$ of the total nitrogen budget of the $\mathrm{MSW}+\mathrm{S}$ reactor, which is inline with low nitrogen content in septage reported by Metcalf and Eddy (1991). In addition, Montangero and Belevi (2007) reported that $85 \%$ of $\mathrm{N}$ is removed via the liquid effluent while $15 \%$ of $\mathrm{N}$ remained in the sludge.

The $\mathrm{NH}_{4}{ }^{+}$(Fig. 3) produced during organic matter conversion (Berge et al., 2005) increased in both reactors to comparable levels, but became relatively higher in the reactor with $\mathrm{MSW}+\mathrm{S}$ due to the fact that more organic matter was converted as conditions were more favourable for the bacterial population as shown by the $\mathrm{pH}$ (Fig. 1a) and biogas production (Fig. 1b) from day 150 onwards. The sharp decrease of $\mathrm{NH}_{4}{ }^{+}$concentration after day 350 in the reactor might be explained by volatilization of $\mathrm{NH}_{3}$ due to high pH levels (Fig. 1a) (Cheung et al., 1997; Kabdasli et al., 2000; Fricke et al., 2007); calculations based on dissolution of $\mathrm{NH}_{4}{ }^{+}$and $\mathrm{NH}_{3}$ depending on $\mathrm{pH}$ values and temperature indicated that approximately $0.068 \mathrm{~m}^{3}$ of $\mathrm{NH}_{3}$ was produced. This volume of $\mathrm{NH}_{3}$ represented $16 \%$ of the total theoretical amount of $\mathrm{NH}_{3}$, which was $0.13 \mathrm{~m}^{3}$ of $\mathrm{NH}_{3}$ produced according to Equation 1 and data from Table $2 . \mathrm{NH}_{4}{ }^{+}$removal via anammox bacteria was quite unlikely, since their growth rate is extremely low and they required $\mathrm{NO}_{2}{ }^{-}$as electron acceptor (Jetten et al., 1998). $\mathrm{NO}_{2}^{-}$could not be sufficiently produced via nitrification of $\mathrm{NH}_{4}{ }^{+}$, due to lack of oxygen intrusion into the reactor as suggested before (Valencia et al., 2008). Maximally $300 \mathrm{mg}$ of $\mathrm{NH}_{4}{ }^{+}$could be converted into $\mathrm{NO}_{2}^{-}$assuming that $1 \mathrm{~L} \mathrm{week}^{-1}$ of recirculated leachate was saturated with oxygen during the entire experiment.

\subsection{Pathogen removal from residues}

The results of the microbiological examinations revealed that approximately $95 \%$ of total and faecal coliforms were supplied by the municipal solid waste. The reduction of total and faecal coliforms (Fig. 4a), $99 \%$ and $100 \%$ respectively, was inline with the results of reported by 
Déportes et al. (1998) and Vanotti et al. (2005) who used disinfection techniques for liquid swine manure. The normal factors for die-off of coliforms in solid waste (high temperature, extreme alkaline $\mathrm{pH}(\mathrm{pH}>11)$ and high EC) as described by Watson-Craik et al. (1992) and Boost \& Poon (1998) were not significantly influential in this experiment. Competition and predation as suggested by Chabaud et al. (2006) were relatively less significant since there was enough initial substrate to prevent competition and predator's activity decreases as salinity in the environment increases as reported by Moussa et al. (2005). Dispersion due to constant recirculation as suggested by Smith et al. (2005) could be considered as an environmental condition to increase the die-off process of pathogens. Factors affecting the die-off of pathogens during this experiment could be initial inactivation caused by low $\mathrm{pH}$ and high VFA as suggested by Salsali et al. (2006), followed by the detrimental effect of high carbonate and ammonia concentrations similar as those reported by Park and Diez-Gonzalez (2003). In addition, the retention time was considerably longer than those reported by Jepsen et al. (1997). However, it was not clear which of these harsh conditions (high salinity, high $\mathrm{H}_{2} \mathrm{~S}$ and/or $\mathrm{NH}_{4}{ }^{+}$concentrations) were the most influential on the die-off process of coliforms during this experiment.

\section{References}

Allen A. (2001). Containment Landfills: the myth of sustainability. Eng. Geol. 60, 3-19.

APHA (2005). Standard Methods for Water and Wastewater Examination, 21st ed. American Public Health Association, Washington, DC.

Barlaz M.A., Ham R.K., Schaefer D.M. (1989). Mass-balance analysis of anaerobically decomposed refuse. J. Environ. Eng-ASCE. 115, 1088-1102.

Berge N.D., Reinhart D.R., Townsend T.G. (2005). Fate of nitrogen in bioreactor landfills. Crit. Rev. Env. Sci. Technol. 35, 365-399.

Bolzonella D., Battistoni P., Susini C., Cecchi F. (2006). Anaerobic codigestion of waste activated sludge and OFMSW: the experiences of Viareggio and Treviso plants (Italy). Water Sci. Technol. 53(8), 203-211.

Boost M.V., Poon C.S. (1998). The effect of a modified method of limestabilisation sewage treatment on enteric pathogens. Environ. Int. 24, 783788. 
Bradley R.M. (1981). Disposal of septic-tank contents in Cyprus. Water Pollut. Control. 80, 131-137.

Buswell A.M., Mueller M.F. (1952). Mechanisms of methane fermentation, Ind. Eng. Chem. 44, 550-552.

Chabaud S., Andres Y., Lakel A., Le-Cloirec P. (2006). Bacterial removal in septic effluent: influence of biofilm and protozoa. Water Res. 40, 31093114.

Chaggu E., Mashauri D., Van Buuren J., Sanders W., Lettinga G. (2002). Excreta disposal in Dar-es-Salaam. Environ. Manage. 30, 609-620.

Chan Y.S.G., Chu L.M., Wong M.H. (1999). Codisposal of municipal refuse, sewage sludge and marine dredgings for methane production. Environ. Pollut. 106, 123-128.

Chen M. (1988). Pollution of groundwater by nutrients and fecal coliforms from lakeshore septic tank systems. Water Air Soil Pollut. 37, 407-417.

Cheung K.C., Chu L.M., Wong M.H. (1997). Ammonia stripping as pretreatment for landfill leachate. Water Air Soil Pollut. 94, 209-221.

Çinar S., Onay T.T., Erdinçler A. (2004). Co-disposal alternatives of various municipal wastewater treatment-plant sludges with refuse. Adv. Environ. Res. 8, 477-482.

Déportes I., Benoit-Guyod J.-L., Zmirou D., Bouvier M.-C. (1998). Microbial disinfection capacity of municipal solid waste (MSW) composting. J. Appl. Microbiol. 85, 238-246.

Finney M., Smullen J., Foster H.A., Brokx S., Storey D.M. (2003). Evaluation of Chromocult coliform agar for the detection and enumeration of Enterobacteriaceae from faecal samples from healthy subjects. $J$. Microbiol. Methods. 54, 353-358.

Fricke K., Santen H., Wallmann R., Hüttner A., Dichtl N. (2007). Operating problems in anaerobic digestion plants resulting from nitrogen in MSW. Waste Manage. 27, 30-43.

Harrison E.Z., Moffe M. (2003). Septage quality and its effects on field life for land application. J. Am. Water. Resour. Assoc. (JAWRA), 39 (1): 87-97.

Hartmann H., Ahring B.K. (2005). Anaerobic digestion of the organic fraction of municipal solid waste: Influence of co-digestion with manure. Water Res. 39, 1543-1552.

He P.-J., Shao L.-M., Qu X., Li G.-J., Lee D.-J. (2005). Effects of feed solutions on refuse hydrolysis and landfill leachate characteristics. Chemosphere 59, 837-844. 
Jepsen S.E., Krause M., Grüttner H. (1997). Reduction of fecal streptococcus and salmonella by selected treatment methods for sludge and organic waste. Water Sci. Technol. 36(11), 203-210.

Jetten M., Strous M., van de Pas-Schoonen K., Schalk J., van Dongen U., van de Graaf A., Logemann S., Muyzer G., van Loosdrecht M., Kuenen J. (1998). The anaerobic oxidation of ammonium. FEMS Microbiol. Rev. 22, 421-437.

Kabdasli I., Tünay O., Öztürk I., Yilmaz S., Arikan O. (2000). Ammonia removal from young landfill leachate by magnesium ammonium phosphate precipitation and air stripping. Water Sci. Technol. 41(1), 237-240.

Kadam P.C., Boone D.R. (1996). Influence of $\mathrm{pH}$ on ammonia accumulation and toxicity in halophilic, methylotrophic methanogens. Appl. Environ. Microbiol. 62, 4486-4492.

Leckie J.O., Pacey J.G., Halvadakis C. (1979). Landfill management with moisture control. J. Environ. Eng-ASCE, 105, 337-355.

Leuschner A.P. (1989). Enhancement of degradation: Laboratory-scale experiments. In Christensen T.H.; Cossu R.; Stagmann R., (Eds.) Sanitary Landfilling: Process Technology and Environmental Impact, pp. 83-102, Academic Press, London.

Metcalf and Eddy (1991). Wastewater Engineering: treatment, disposal and reuse, $3^{\text {rd }}$ Ed. McGraw-Hill publishers, New York.

Montangero A., Belevi H. (2007). Assessing nutrients flows in septic tanks by eliciting expert judgement: A promising method in the context of developing countries. Water Res. 41, 1052-1064.

Moussa M.S., Hooijmans C.M., Lubberding H.J., Gijzen H.J., van Loosdrecht M.C.M. (2005). Modelling nitrification, heretotrophic growth and predation in activiated sludge. Water Res. 39, 5080-5098.

NDUDP (2001). Nad Dinh Urban Development Project: Septage Management Study. COLENCO; SANDEC, EAWAG, November, 2001; http://www.eawag.ch/organisation/abteilungen/sandec/publikationen/publi cations_ewm/downloads_ewm/ND_septage_management_study.pdf (last accessed, July 2007).

Neves L., Oliveira R., Alves M.M. (2006). Anaerobic co-digestion of coffee waste and sewage sludge. Waste Manage. 26, 176-181.

Park G.W., Diez-Gonzalez F. (2003). Utilization of carbonate and ammoniabased treatments to eliminate Escherichia coli O157:H7 and Salmonella Typhimurium DT104 from cattle manure. J. Appl. Microbiol. 94, 675-685. 
Reinhart D.R., Townsend T.G. (1998). Landfill Bioreactor Design \& Operation. Lewis Publisher, New York, United States of America.

Salsali H.R., Parker W.J., Sattar S.A. (2006). Impact of concentration, temperature, and $\mathrm{pH}$ on inactivation of Salmonella spp. by volatile fatty acids in anaerobic digestion. Can. J. Microbiol. 52, 279-286.

Silva W.L., Duarte V.L., Prasad S. (2004). Influence of inoculum on performance of anaerobic reactors for treating municipal solid waste. Bioresour. Technol. 94, 261-266.

Smith S.R., Lang N.L., Cheung K.H.M., Spanoudaki K. (2005). Factors controlling pathogen destruction during anaerobic digestion of biowastes. Waste Manage. 27, 417-425.

Tchobanoglous G., Kreith F. (2003). Handbook of solid waste management. McGraw-Hill publishers, New York.

Valencia R., van der Zon W., Elpido E., Lubberding H.J., Gijzen H.J. (2005). Codigestion of municipal solid waste and septic tank sludge in bioreactor landfill simulators. In T.H. Christensen, R. Cossu, R. Stegmann (Eds.): Sardinia 2005 "Tenth International Waste Management and Landfill Symposium” October 3-7, 2005, S. Margherita di Pula, Cagliari, Italy.

Valencia R., van der Zon W., Woelders H., Lubberding H.J., Gijzen H.J. (2008). Achieving "Final Storage Quality" of municipal solid waste in pilot scale bioreactor landfills. Waste Manage. (2008) in press.

DOI: 10.1016/j.wasman.2008.02.008

Vanderzant C., Splittstoesser D.F. (1992). Compendium of methods for the microbiological examination of foods $3^{\text {rd }}$ Ed., 1208 pp. American Public Health Association, Washington, D.C.

Vanotti M.B., Millner P.D., Hunt P.G., Ellison A.Q. (2005). Removal of pathogen and indicator microorganisms from liquid swine manure in multi-step biological and chemical treatment. Bioresour. Technol. 96, 209214.

Watson-Craik I.A., Sinclair J.K., Senior E. (1992). Landfill co-disposal of wastewater and sludges. In: Fry J.C., Gadd G.M., Herbert R.A., Jones C.W., Watson-Craik I.A (Eds.). Microbial control of pollution, Fortyeighth Symposium of the Society for General Microbiology, Cardiff U.K. 


\title{
4 \\ Chapter
}

\section{The effect of hydraulic conditions on waste stabilisation in bioreactor landfill simulators}

It is common sense to take a method and try it. If it fails, admit it frankly and try another. But above all, try something.

Franklin D. Roosevelt (1882 - 1945)

\begin{abstract}
Seven Bioreactor Landfill simulators (mixed gravel, gravel in layers, and controls without gravel with two levels of compaction, i.e. normal and lower density) were used to investigate the effect of different hydraulic conditions on the waste stabilisation process. The simulators with mixed gravel performed better by absorbing the temporal and spatial changes of the MSW particles, which allowed better contact of liquids and solids thus providing favourable conditions for micro-organisms to enhance the waste stabilisation process. Moreover, neutral $\mathrm{pH}$ levels seemed to be the "driving force" that enhanced physical, chemical and biological processes contributing to waste stabilisation in the simulators. After one year of operation, the residues of the different simulators were very close to achieving a Final Storage Quality status comparable to the Waste Acceptance Criteria for inert waste of the European Landfill Directive.
\end{abstract}

Accepted for publication in Bioresource Technology as:

The effect of hydraulic conditions on waste stabilization in bioreactor landfills

simulators. Valencia R., van der Zon W., Woelders H., Lubberding H.J., Gijzen H.J. 2008. 


\section{Introduction}

Municipal solid waste (MSW) placed in sanitary landfills undergoes a sequential decomposition process, which may last from few weeks (i.e. aerobic phase) up to several decades or even centuries (i.e. methanogenesis phase) (Allen, 2001; Evans 2001; Pohland, 1996). Many researchers have investigated the controlling factors of the sequential phases of MSW stabilisation (Gurljala and Suflita, 1993; Hartz et al., 1982; Klink and Ham, 1982; Leckie et al., 1979), and have suggested that moisture content is the most critical one. The efforts (i.e. enhancement techniques) to influence these critical factors resulted in the concept of operating a landfill as a bioreactor, the so-called Bioreactor Landfill approach. Most common enhancement techniques used in laboratory, pilot and field-scale are: leachate recirculation, addition of nutrients and buffers, seeding with alternative waste materials, leachate pre-treatment, or combinations of these (Kinman et al., 1987; Reinhart et al., 2002; Reinhart and Townsend, 1998; Warith, 2002; Yuen et al., 2001). Leachate recirculation has been the most widely used technique (i.e. vertical and horizontal injection, surface ponds, leachate spraying and hydraulic blankets) with relatively good results, especially a combination of horizontal and vertical injection (Benson et al., 2007; Haydar and Khire, 2005; Khire and Mukherjee, 2007; Miller and Emge, 1997; Reinhart and Al-Yousfi, 1996; Townsend et al., 1995; Warith et al., 2001). However, the effective influence of these methods is limited to the central part of the landfill. The effectiveness of the chosen recirculation method is governed by the hydraulic properties of the MSW and the occurrence of preferential pathways (channelling), which leaves dry-spots within the waste matrix (McCreanor and Reinhart, 1999; Rosqvist et al., 2005; Rosqvist and Destouni, 2000).

Since MSW is highly heterogeneous and the physical properties change, not only spatially, but also temporally, the preferred recirculation method should be able to absorb these changes in order to maintain a constant leachate flow and homogenous distribution within the changing waste matrix. Addition of materials (i.e. in layers or mixtures) has not been tried before and could contribute to the effectiveness of the recirculation methods by "breaking" the channelling effect and redistributing the recirculated leachate homogenously. The objective of this study is to 
investigate the impact of different hydraulic regimes on the MSW stabilisation process by adding inert materials in Bioreactor Landfills.

\section{Material and methods}

\subsection{Bioreactor Landfill simulators setup and operation}

Seven bioreactor landfills were simulated using high density polyethylene (HDPE) sewage pipes (3 cm wall thickness) of $70 \mathrm{~cm}$ diameter and $200 \mathrm{~cm}$ high, hermetically sealed with attached and welded HDPE lids at the top and bottom ends of the simulators, respectively. Schematic views and photographs of the simulators can be seen at Annex 1. At the top, unidirectional gas meters (Meterfabriek Schlumberger) were installed to measure the biogas production and inlets for leachate recirculation. The produced leachate was collected in a reservoir at the bottom of the reactor and was recirculated into the simulator using a high-speed pump. The internal temperature of the simulators was measured by means of two online temperature sensors placed at 50 and $150 \mathrm{~cm}$ from the bottom. Internal temperature was maintained at $30 \pm 4^{\circ} \mathrm{C}$ as explained in Valencia et al (2008). The simulators were filled with shredded (particle size max. $4 \mathrm{~cm}$ ) MSW, collected and characterized at the transfer station in Wijster, The Netherlands as shown in Table 1.

Table 1. Composition of the municipal solid waste.

\begin{tabular}{lc}
\hline Component & Percentage (wet weight) \\
\hline Organic undefined & 33.2 \\
Paper \& cardboard & 15.2 \\
Plastics & 3.7 \\
Glass & 13.6 \\
Ferrous metals / non-ferrous metals & 0.6 \\
Leather/rubber & 0.2 \\
Wood & 2.5 \\
Inert $(>3.4 \mathrm{~mm})$ & 13.7 \\
Inert $(<3.4 \mathrm{~mm})$ & 15.2 \\
Textiles & 2.1 \\
\hline
\end{tabular}

Source ESSENT Milieu 2006 at transfer station in Wijster, The Netherlands (Provided by H. Woelders).

The different configuration features of the bioreactor landfill simulators are shown in Table 2 and schematic views can be seen at Annex 1. Two gravel layers $(5 \mathrm{~cm})$ were placed in simulators 1 and 2 , whereas the 
same amount of MSW and gravel was homogenously mixed and placed in simulators 3 and 4. The control simulators (5,6 and 7) had no gravel and were filled with the same total weight of MSW and gravel (5 and 6) or filled with only the weight of MSW contained in simulators 1-4, but compacted with less density (7).

Since operational conditions changed after day 250, simulators 5 and 6 served as control until that day. $124 \mathrm{~L}$ tap water with a $0.1 \mathrm{M} \mathrm{NaHCO}_{3}{ }^{-}$was added to all simulators at the start of the experiment in order to reach field capacity and to stimulate leaching conditions as suggested by Vroon et al (1999) and to reduce the impact of the initial acidification caused by the excessive production of intermediate hydrolytic products (Valencia et al, 2008). The produced leachate was recycled without any pre-treatment at least 3 times per week $\left( \pm 30 \mathrm{~L}\right.$ week $\left.^{-1}\right)$ in order to maintain a dynamic leachate flow and at least $45 \%$ moisture content (field capacity) on a wet weight basis. Buffer $\left(0.3 \mathrm{M} \mathrm{NaHCO}_{3}^{-}\right)$was added to the leachate prior to recycling during a period of 6 weeks (day 50-100) to reduce the negative impact of the VFA on the $\mathrm{pH}$.

Table 2. Configuration features of the Bioreactor Landfill simulators.

\begin{tabular}{llccc}
\hline Simulator & Variable & $\begin{array}{c}\text { Quantity } \\
\text { MSW* }\end{array}$ & $\begin{array}{c}\text { Quantity } \\
\text { gravel }\end{array}$ & $\begin{array}{c}\text { Quantity } \\
\text { liquid } \\
\text { added }\end{array}$ \\
\hline Simulator 1-2 & 2 layers of gravel & $330 \mathrm{~kg}$ & $100 \mathrm{~kg}$ & $124 \mathrm{~L}$ \\
Simulator 3-4 & Gravel \& MSW mixed & $331 \mathrm{~kg}$ & $100 \mathrm{~kg}$ & $124 \mathrm{~L}$ \\
Simulator 5-6 & Control & $428 \mathrm{~kg}$ & $0 \mathrm{~kg}$ & $124 \mathrm{~L}$ \\
Simulator 7 & Control less density & $350 \mathrm{~kg}$ & $0 \mathrm{~kg}$ & $124 \mathrm{~L}$ \\
\hline
\end{tabular}

* On a wet weight basis.

\subsection{Analytical procedures}

Moisture and volatile solids content of the MSW were analysed according to Standard Methods (APHA, 2005). Additionally, a leaching test (NEN-EN 12457-4) was conducted in triplicate to determine the leaching potential of COD, BOD, TOC, $\mathrm{NH}_{4}{ }^{+}$, selected ions $\left(\mathrm{Cl}^{-}, \mathrm{NO}_{3}{ }^{-}, \mathrm{PO}_{4}{ }^{3-}, \mathrm{SO}_{4}{ }^{2-}\right)$ and heavy metals $(\mathrm{Pb}, \mathrm{Ni}, \mathrm{Zn}, \mathrm{Cu}, \mathrm{Cd})$ from the solid waste according to European Standards (CEN, 2002). The elemental composition (CHNS) of the MSW was determined by flash combustion in a partial oxygen atmosphere using helium as carrier, at $1020^{\circ} \mathrm{C}$ with a Thermo Quest EA 
1110 Interscience elemental analyser. Leachate samples were analysed for $\mathrm{pH}$, temperature, conductivity and oxygen with portable meters WTW $\mathrm{pH}$ 340, LF 340 and Oxi 345, respectively. $\mathrm{COD}, \mathrm{BOD}, \mathrm{NH}_{4}{ }^{+}$, VFA were analysed according to Standard Methods (APHA, 2005). TOC was determined using an OI Corporation TOC Analyser M-700. Volatile fatty acids (VFA) were measured with a Chrompack CP9001 gas chromatograph, equipped with a FID and fitted with a Chrompack column (CP-FFAP-CB 25 $\mathrm{m} \times 0.53 \mathrm{~mm}, 1 \mu \mathrm{m}$ ) using helium as carrier gas, coupled with a Shimadzu C-R5A Chromatopac integrator. Heavy metals were analysed with a Perkin Elmer Atomic Absorption Spectrometer 3110 flame detector. Ions were analysed using an Ion Chromatography system DIONEX ICS-1000 attached with an automated sample injector DIONEX ASI-100. All liquid samples were filtered with glass fibre filters GF 52, Schleicher \& Schuell. Biogas composition $\left(\mathrm{CH}_{4}, \mathrm{CO}_{2}\right.$ and $\left.\mathrm{O}_{2}\right)$ was monitored using a Geotechnical Instruments GA25 portable gas extraction analyser.

\subsection{Statistical analyses}

Since the variation of the results of all parameters among simulators was minimal, the graphs were elaborated using the average results of the two replicates (simulators). For the biological parameters (BOD, COD and TOC) eight samples were used to calculate each simulator average, whereas for $\mathrm{NH}_{4}{ }^{+}, \mathrm{Cl}^{-}, \mathrm{SO}_{4}{ }^{2-}$ and $\mathrm{PO}_{4}{ }^{3-}$, four samples were used to calculate the average. However, due to larger differences in the results of the elemental mass balances and leaching tests, the results are reported by simulator in order to avoid a biased conclusion.

\section{$3 \quad$ Results}

\subsection{Process parameters}

Initially, $\mathrm{pH}$ values (Fig 1a, 1c) in all simulators were slightly below 6 and increased up to 6.5 in the first 2 weeks of operation. After decreasing sharply to values around $5.5, \mathrm{pH}$ remained constant for about 100 days, while afterwards $\mathrm{pH}$ values increased steadily up to the range between 7 and 8. The simulators with gravel responded faster to the addition of buffer (between day 50 and 100) than the control simulators. Nevertheless, the simulators with mixed gravel and less density control achieved higher 
overall $\mathrm{pH}$ values (above 7.5) than the ones with gravel in layers and the controls, suggesting a better leachate mixing within the simulators.
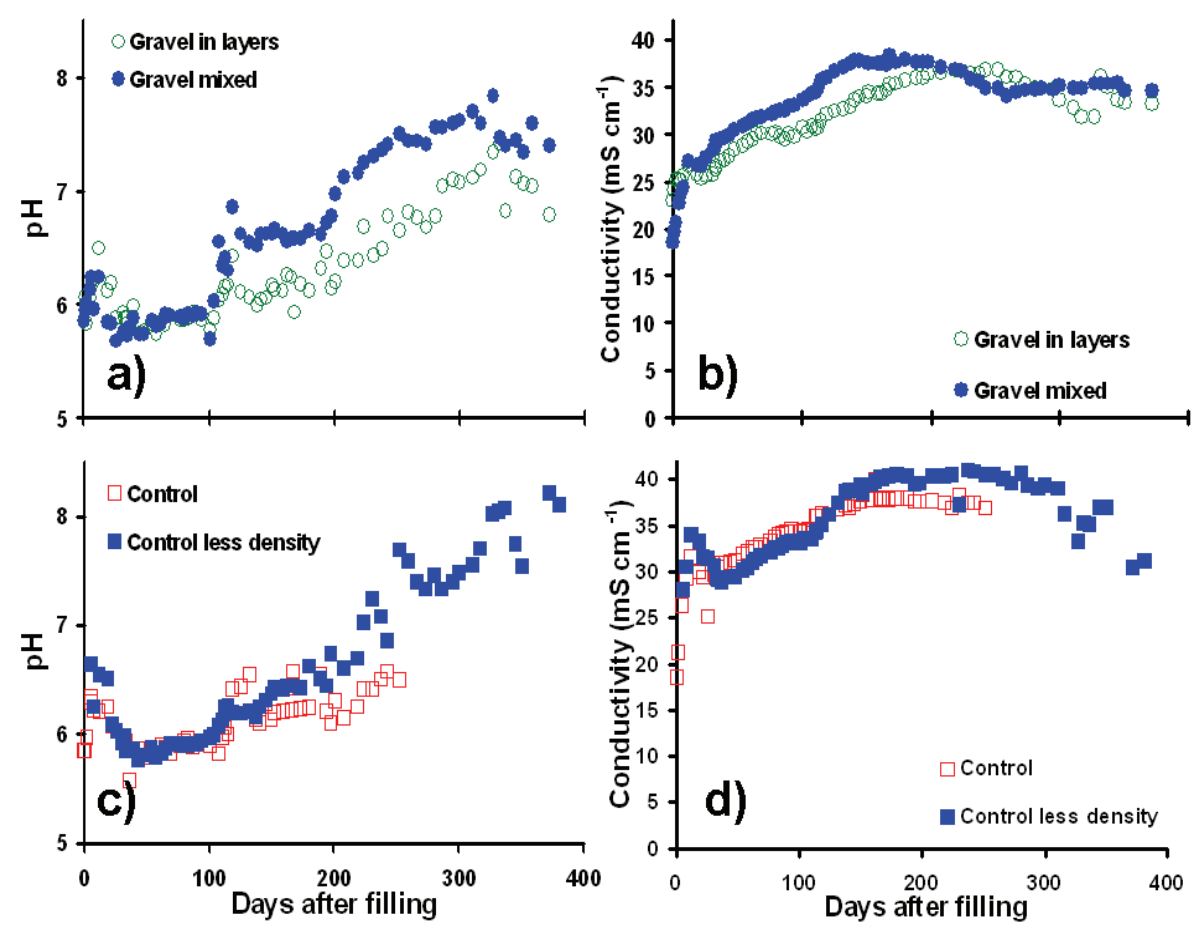

Figure 1. $\mathrm{pH}$ and conductivity of the leachate in the simulators with gravel (a, b) and controls (c, d).

Electrical conductivity (EC) of the leachate (Fig 1b, 1d) increased gradually from $20 \mathrm{mS} \mathrm{cm}^{-1}$ up to maximum values between 35 and $40 \mathrm{mS}$ $\mathrm{cm}^{-1}$ at day 200. The EC of all simulators remained constant, except the less density simulator in which the EC decreased slightly after day 300.

\subsection{Biological parameters}

During the first 100 days all simulators produced about $5 \mathrm{~m}^{3}$ of biogas (Fig. 2a, 2c), with an average biogas composition of $15 \% \mathrm{CH}_{4}-75 \% \mathrm{CO}_{2}-$ $10 \% \mathrm{O}_{2}$. From day 150 the exponential biogas production started, which corresponded with a rapid decrease of VFA in the leachate (Fig 2b, 2d). Also the biogas composition changed to $64 \% \mathrm{CH}_{4}-34 \% \mathrm{CO}_{2}-0.5 \% \mathrm{O}_{2}$ in the simulators with mixed gravel and the less density control and $56 \% \mathrm{CH}_{4}$ $41 \% \mathrm{CO}_{2}-1.5 \% \mathrm{O}_{2}$ for the simulator with gravel in layers. At day 250 , the 
control simulators had produced $8 \mathrm{~m}^{3}$ of biogas with a composition of $25 \% \mathrm{CH}_{4}-55 \% \mathrm{CO}_{2}-2.5 \% \mathrm{O}_{2}$, which was inline with the amount of VFA still present in the simulators.
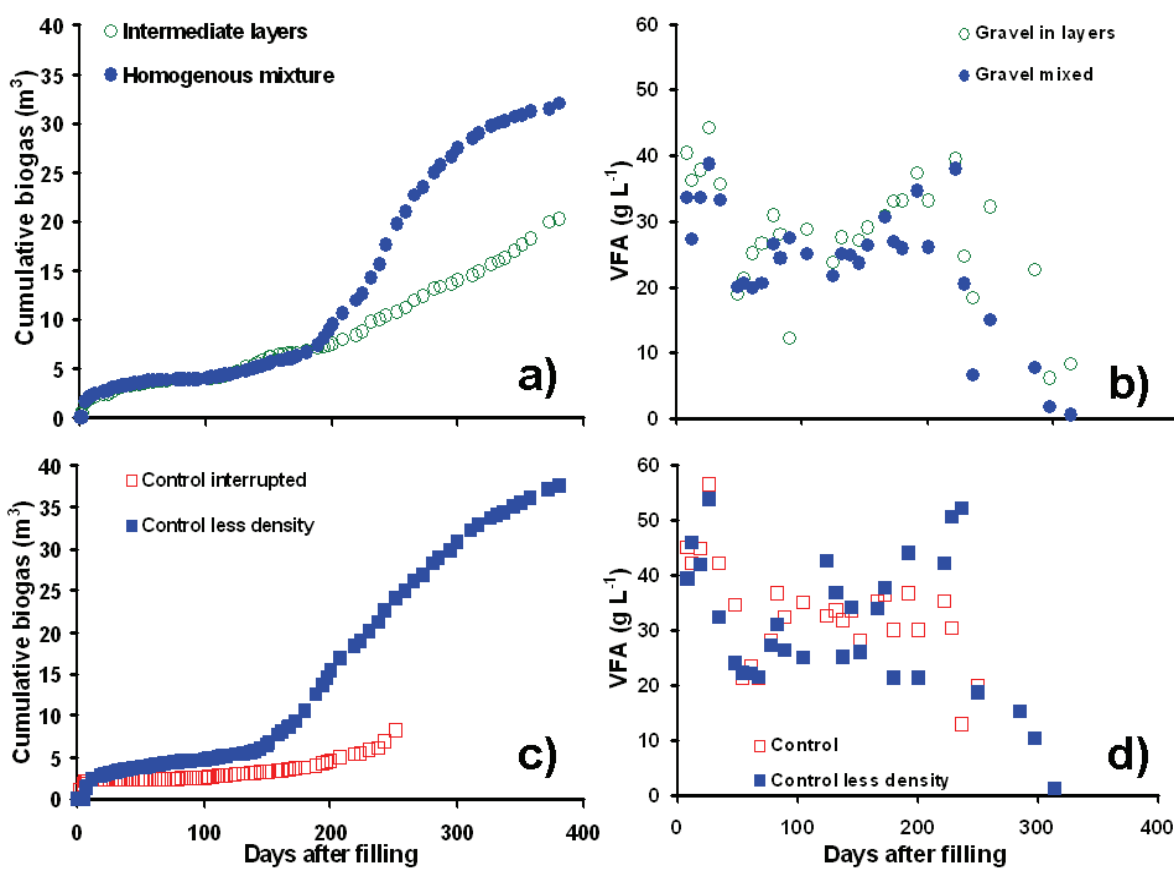

Figure 2. Cumulative biogas production and volatile fatty acids (VFA) of the simulators with gravel $(\mathbf{a}, \mathbf{b})$ and the controls $(\mathbf{c}, \mathbf{d})$.

$\mathrm{BOD} / \mathrm{COD}$ ratio in the leachate was used to follow the biodegradability of the waste (Fig. 3a, 3b). BOD/COD in all simulators decreased faster (i.e. from day 200 onwards) as more organic matter was converted into biogas, reaching values around 0.3 or lower towards the end of the experiment. BOD/COD of the control did not decrease yet and was 0.7 at day 250.

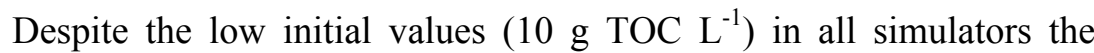
TOC (Fig.3 b-d) increased immediately to values around $25 \mathrm{~g} \mathrm{TOC} \mathrm{L}^{-1}$. Similar to the BOD/COD ratio, the TOC of all simulators decreased after day 150 which corresponded with the start of the exponential biogas production and VFA reduction from the leachate. After day 150, the TOC of the gravel in layers simulators did not decrease further and remained relatively constant up to the end of the experiment at $15 \mathrm{~g} \mathrm{TOC} \mathrm{L}^{-1}$. 

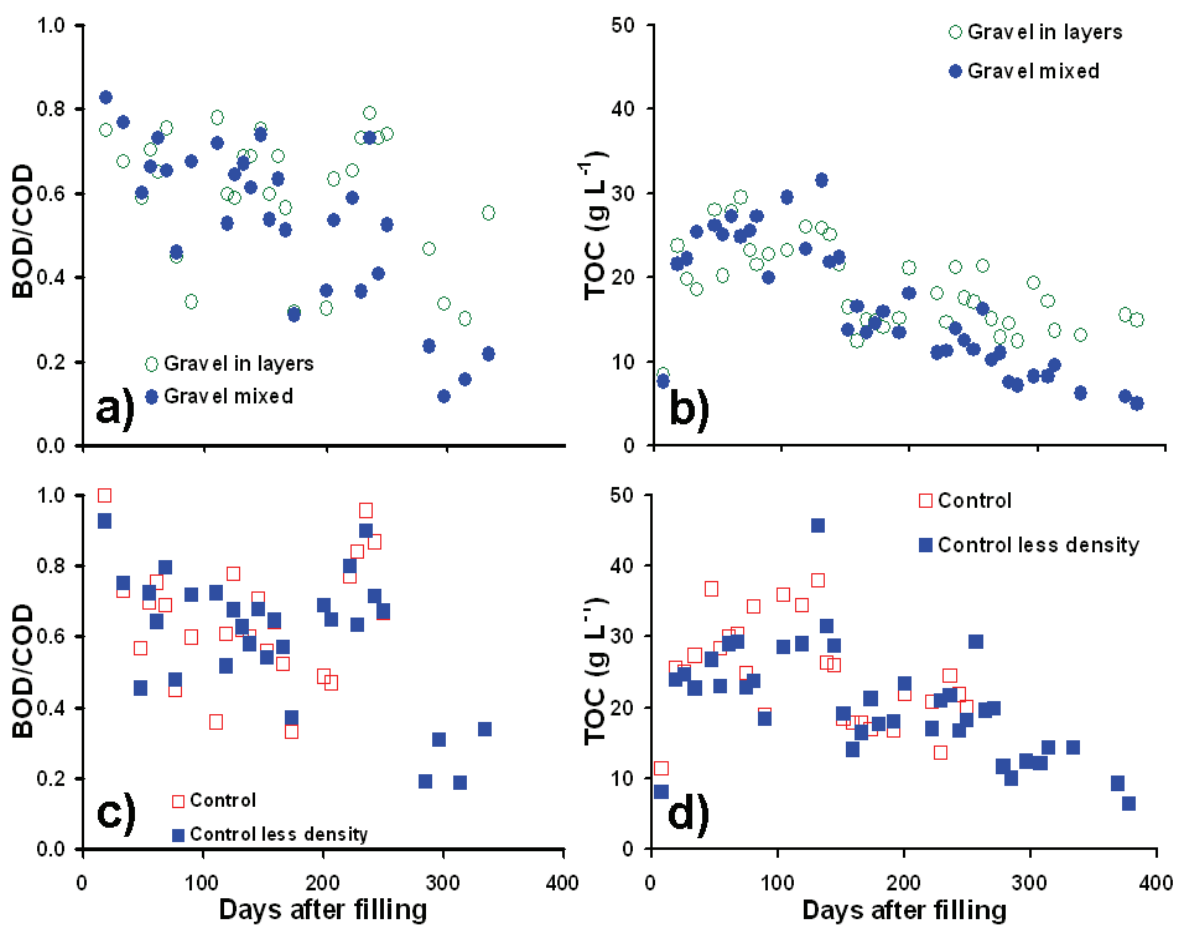

Figure 3. BOD/COD ratio and TOC in the leachate from the simulators with gravel (a, b) and controls (c, d).

The ammonium concentration in the leachate (Fig. 4a, 4b) of all simulators increased from $1 \mathrm{~g} \mathrm{~L}^{-1}$ up to maximally $3 \mathrm{~g} \mathrm{~L}^{-1}$ in the first 200 days of operation. After day 200 the concentration in all simulators decreased to about $1.5 \mathrm{~g} \mathrm{~L}^{-1}$. However, no further decrease was observed towards the end of the experiment. The decrease in ammonium coincided not only with the start of the exponential biogas production, but also with the VFA and BOD/COD decrease.

The chloride concentration in the leachate (Fig. 4c, 4d), first measured after 50 days, was in all simulators between 2.5 and $3 \mathrm{~g} \mathrm{~L}^{-1}$, but decreased slightly towards the end of the experiment to values around $2 \mathrm{~g} \mathrm{~L}^{-1}$.

The phosphate (Fig. 4e, 4f) concentration in the leachate of all simulators was relatively constant around $0.05 \mathrm{~g} \mathrm{~L}^{-1}$ during the course of the experiment. 

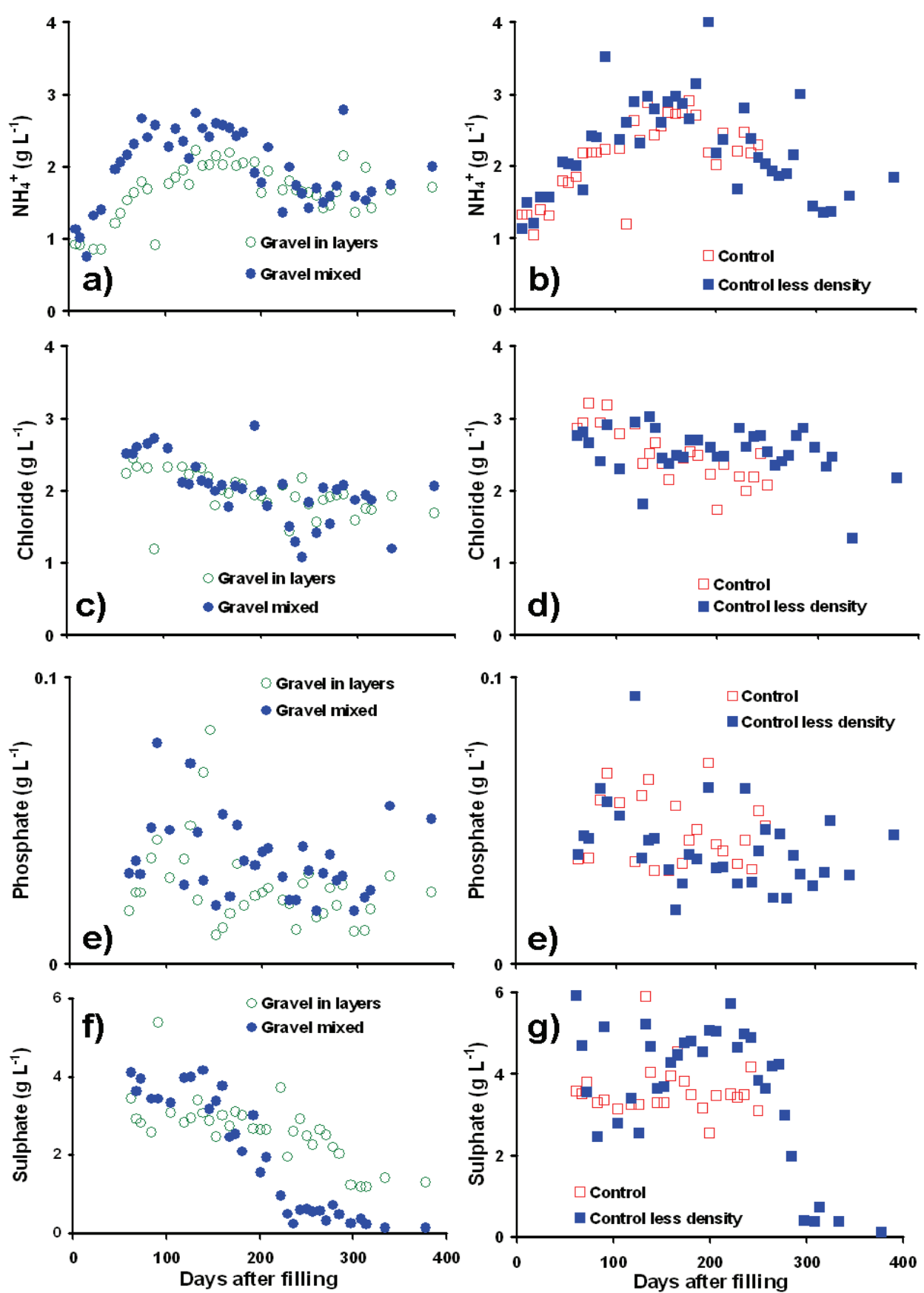

Figure 4. Ammonium, chloride, phosphate and sulphate in the leachate of the simulators with gravel (a, $\mathbf{c}, \mathbf{e}, \mathbf{g})$ and the controls $(\mathbf{b}, \mathbf{d}, \mathbf{f}, \mathbf{h})$. 
The sulphate concentration in the leachate (Fig $4 \mathrm{~g}, 4 \mathrm{~h}$ ), first measured at day 50 , decreased from 4 to $6 \mathrm{~g} \mathrm{~L}^{-1}$ to values close to zero towards the end of the experiment. The simulators with gravel showed earlier decreasing trends compared to the less density simulators that decreased sharply after day 250. The sulphate concentration decrease corresponded with the reaching of neutral $\mathrm{pH}$ values $(\mathrm{pH} \geq 7)$. The sulphate in the control simulator did not change within 250 days of operation.

\subsection{Degree of waste stabilization}

The initial and final characteristics of the waste and residues from the bioreactor landfill simulators are shown in Table 3. Volatile solids (VS), on a dry weight basis, were reduced by $18 \%, 26 \%, 35 \%$, and $27 \%$ from their original contents for the simulators with gravel in layers, mixed with gravel, control and control with less density, respectively. Accordingly, an average reduction of the basic elements $(C, N, H, S)$ content of the residues, $14 \%$, $11 \%, 24 \%$ and $40 \%$, respectively was observed.

\section{Discussion}

\subsection{Process parameters}

All simulators showed a similar decreasing trend in $\mathrm{pH}$ values, commonly caused due to the accumulation of hydrolytic products during the first weeks of operation (Ağdağ and Sponza, 2005; Veeken et al., 2000; Warith, 2002). Such sudden pH drop can be reduced to one week in systems with leachate recirculation (Pohland and Kim, 1999). In our experiment, however, the initial $\mathrm{pH}$ increase (Fig. 1a, 1c) observed in all simulators was most likely due to the addition of buffer. The supplement of $\mathrm{NaHCO}_{3}{ }^{-}$to the recycled leachate helped to increase the buffering capacity of the leachate from day 100 onwards, raising the $\mathrm{pH}$ values near the neutral range, which is optimal for methanogens (A ğdağ and Sponza, 2005). After day 200, more acclimatised and predominant methanogenic bacteria in the simulators converted the accumulated VFA faster into biogas (Fig. 2a-d), which together with the ammonium release during hydrolysis of proteins (Berge et al, 2005) helped to increase the pH (A ğdağ and Sponza, 2005; Chen, 1996; Dinamarca et al., 2003). The simulators with mixed gravel and less density 
exhibited a faster overall response, by reaching neutral $\mathrm{pH}$ ranges in a shorter period of time, suggesting a better liquid/solid contact within the simulators.

\subsection{Biological parameters}

Biogas production showed usual lag-phases as reported in similar bioreactor landfill experiments (Al-Yousfi and Pohland, 1998; Ledakowicz and Kaczorek, 2004; Mehta et al., 2002; Morris et al., 2003). The biogas (Fig. 2a, 2c) was initially mainly composed of $\mathrm{CO}_{2}( \pm 80 \%)$, which is expected during the transition and acid formation phases of anaerobic digestion of organic matter (Evans, 2001; Pohland and Kim, 1999; Reinhart and Al-Yousfi, 1996) and the constant degassing phenomenon from the liquid phase into the gas phase. However from day 150, as environmental conditions were more favourable (i.e. higher $\mathrm{pH}$ ), methanogens started to dominate the systems, clearly seen by the exponential increase of the biogas, the higher $\mathrm{CH}_{4}$ content (up to $70 \%$ ) and the concomitant depletion of VFA (Fig. 2b, 2d). The average biogas yields observed during these experiments $0.26,0.13$ and $0.30 \mathrm{~m}^{3}$ of $\mathrm{CH}_{4} \mathrm{~kg}^{-1} \mathrm{VS}$ converted for mixed gravel, gravel in layers and the less density simulators, respectively, were comparable with literature (Barlaz et al., 1989; Davission et al., 2007; Reinhart and Townsend, 1998). The lower biogas yields of the intermediate layers simulators could be attributed to a suboptimal contact between liquids and solids within the simulators as also shown by the late response of the $\mathrm{pH}$ and the more gradual EC increase of the leachate (Fig. 1a, 1d). All simulators were sampled at day 350 and it was observed that in the simulators with gravel in layers a "semi-impermeable" muddy layer was formed under the bottom layer of gravel, leaving the bottom layer of waste almost in its original state. This amount of intact waste has caused the lower biogas yields and higher TOC and BOD/COD values towards the end of the experiment. More detailed determinations revealed that these layers of waste also had higher VS content; after correction biogas yield for theses simulators was $0.23 \mathrm{~m}^{3}$ of $\mathrm{CH}_{4} \mathrm{~kg}^{-1} \mathrm{VS}$ converted. 


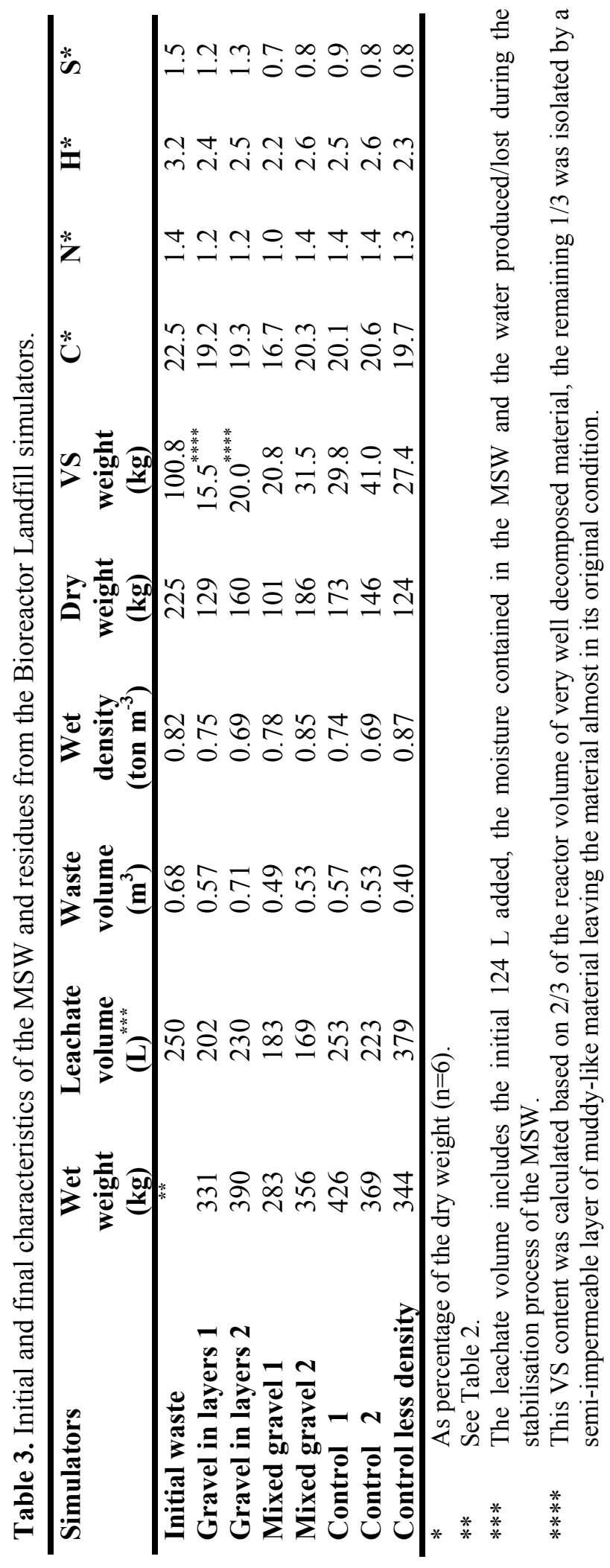


The BOD/COD ratio is commonly used to depict the degree of biodegradable organic carbon of the system (A ğdağ and Sponza, 2005; Ledakowicz and Kaczorek, 2004) According to the values reached at the end of the experiment $(\mathrm{BOD} / \mathrm{COD}=0.2)$ the simulators were comparable to stable methanogenic landfills older than 20 years (Benson et al., 2007; Kjeldsen et al., 2002). The decrease of the BOD/COD was inline with the decrease of VFA which were converted into biogas (Fig. 2a, 2d). The less density simulator reached BOD/COD values similar to the mixed gravel simulator; however, the ratio decreased sharply only after day 250 , which corresponded with the achievement of neutral pH levels (Fig. 1c). Accordingly, TOC values of all simulators also decreased as more VFA were converted into biogas. Higher BOD/COD and TOC values of the gravel in layers simulator were an indication that organic matter was still not hydrolysed and converted into biogas. The fact that BOD/COD and TOC values decreased faster in the mixed gravel and less density simulators may be an indication that the recirculated leachate was better distributed, thus providing better conditions for micro-organisms. The time needed to reach neutral $\mathrm{pH}$ and biological values described before, was half of the time previously reported by Valencia et al. (2008). This may be explained by the improved hydraulic conditions and buffer addition in the current simulators which helped to provide better contact between liquids and solids and to reach the neutral $\mathrm{pH}$ level faster. Moreover, it is tempting to conclude that $\mathrm{pH}$ is the possible "driving force" to trigger all processes: as soon as it becomes neutral all processes start.

There was sufficient BOD and COD to theoretically reduce all the sulphate into sulphides (Lens et al., 1998). Since $\mathrm{pH}$ levels were never higher than 8 , most of the sulphides were present as $\mathrm{H}_{2} \mathrm{~S}$ (Jang and Townsend, 2001), which could be removed from the reactors through the gas phase or by precipitation with heavy metals. The sulphur mass balances indicated that all reactors received $3 \mathrm{~kg}$ of $\mathrm{S}$ of which only about $0.7 \mathrm{~kg}$ was recovered as residual $\mathrm{S}$. If theoretically all $\mathrm{SO}_{4}{ }^{2-}$ was converted into $\mathrm{H}_{2} \mathrm{~S}$ and escaped via the gas phase, it could account for about $1 \mathrm{~kg}$ of S. The $\mathrm{SO}_{4}{ }^{2-}$ was measured at the bottom of the simulators where conditions were not optimal; supposedly better conditions in the upper layers could lead to higher conversion rates of $\mathrm{SO}_{4}{ }^{2-}$ into $\mathrm{H}_{2} \mathrm{~S}$ that may cover the unaccounted fraction of $1.4 \mathrm{~kg}$ of $\mathrm{S}$. If that was the case, $\mathrm{H}_{2} \mathrm{~S}$ content in the biogas could be as 
much as $2.5 \%$ of the total biogas volume produced, which exceeds the typical $\mathrm{H}_{2} \mathrm{~S}$ concentration in landfill gas (Tchobanoglous and Kreith, 2002). However, higher $\mathrm{H}_{2} \mathrm{~S}$ concentrations have been reported before in literature (Kim et al., 2005; Schieder et al., 2003). During the experiments, 12 incidental $\mathrm{H}_{2} \mathrm{~S}$ measurements were carried out with sampling tubes showing concentrations higher than $4000 \mathrm{mg} \cdot \mathrm{L}^{-1}$, exceeding the capacity of the sampling tubes. $\mathrm{SO}_{4}{ }^{2-}$ reduction was inline with the reduction of BOD and $\mathrm{COD}$ in the simulators. The $\mathrm{SO}_{4}{ }^{2-}$ drop corresponded, in all cases, with the moment at which $\mathrm{pH}$ values were within the neutral range, which is the optimal $\mathrm{pH}$ range for sulphate-reducing bacteria (Lens et al., 1998; Wu and Lee, 2004). The fact that the control simulators never reached neutral $\mathrm{pH}$ values and hence no $\mathrm{SO}_{4}{ }^{2-}$ reduction was observed supports the hypothesis of neutral $\mathrm{pH}$ levels as the "driving force" to trigger all biological and chemical processes in systems operating under the Bioreactor Landfill approach.

Ammonium $\left(\mathrm{NH}_{4}^{+}\right)$, the end product of protein degradation (Berge et al., 2005), in all simulators followed similar trends, starting at $1 \mathrm{~g} \mathrm{~L}^{-1}$ and ending at $2 \mathrm{~g} \mathrm{~L}^{-1}$; however, they reached different maximum levels. The difference between gravel simulators could be attributed to more waste being converted in the simulator with mixed gravel since a fraction of waste was still not degraded in the simulators with layers of gravel. The control simulators produced more ammonium $\left(\max 3 \mathrm{~g} \mathrm{~L}^{-1}\right.$ ) due to the higher amounts of organic matter placed in the simulators (Table 1). However, the less density simulators, which had approximately the same amount of waste as the simulators with gravel, produced more ammonium. This difference could be attributed to the hydraulic conditions that allowed a much better contact between liquids and solids enhancing the degradation of proteineous material. The decrease of ammonium in all simulators could be attributed to nitrification of the leachate after recirculation and/or removal via anammox. It was observed that minimal quantities of oxygen were introduced into the simulators during the recirculation processes of leachate. These minimal amounts of oxygen could lead to full nitrification to $\mathrm{NO}_{3}^{-}$, but also to partial nitrification to $\mathrm{NO}_{2}^{-}$, similar as in the Canon process (Strous et al., 1997). This nitrite could then be converted together with ammonium (1:1 ratio) to $\mathrm{N}_{2}$ by anammox bacteria (Jetten et al., 1998). Due to the presence of hydrazine ( $>6 \mathrm{mg} \mathrm{L}-1)$, an intermediate of anammox metabolism (Van Niftrik et al., 2004), it is tempting to assume the presence of anammox 
bacteria in the simulators. The fact that ammonium levels remained stable from day 200 onwards could suggest that a dynamic equilibrium was established within the simulators, where the supply of ammonium was equal to the conversion rates by the aforementioned processes. In addition, from day 200 onwards the $\mathrm{pH}$ values (Fig. 1a, 1c) were neutral, which are optimal for nitrifying and anammox bacteria (Jetten et al., 1998; Strous et al., 1997). Alternatively, ammonium levels may have decreased due to struvite precipitation. Simulations using PHREEQC program (version 2.10.0.0, Nov 2004; Parkhurst and Appelo, 1999) revealed that according to the ammonium, phosphate and magnesium concentrations and neutral $\mathrm{pH}$ levels of the leachate this could be theoretically possible (data not shown), although struvite concentrations were never measured. This theoretical struvite production could explain the constantly low levels of phosphate in the leachate.

Chloride in all reactors was constant, with a slight decrease towards the end of the experiment. The decrease was not significant to argue washout effect, but it seemed a dilution effect caused by constant recirculation and more homogeneous liquid distribution within the simulators. This means that final concentrations were in fact the actual chloride concentrations of the simulators, since chloride is a very conservative parameter for which no removal mechanisms under anaerobic conditions exist (Bilgili et al., 2007).

\subsection{Carbon and nitrogen mass balance}

The mass balances revealed that approximately $30 \%$ and $10 \%$ of carbon and nitrogen, respectively, were released either into the liquid or gas phases. Since biogas production reduced considerably towards the end of the experiment, the remaining carbon and nitrogen content of the residues could it be of a hardly biodegradable nature or not reachable by micro-organisms due to impermeable layers. Additionally, a high percentage of plastics and woody material, which are not or hardly biodegradable under anaerobic conditions (Bayer et al., 2007; Kim and Townsend, 2007), was observed by visual inspection during the final sampling of the simulators. The recovery rates of the carbon balances were very similar to those reported before by Barlaz et al. (1989), whereas the nitrogen recovery rates were relatively low since no $\mathrm{N}$ determinations were done in the gas phase. The balances were calculated using the dry weight and the elemental content of the MSW. 
Because the simulators were not emptied immediately after 350 days, the wet weight was calculated indirectly, using the density of extracted samples $( \pm 20 \mathrm{~kg})$ and final measures of the simulators. This indirect approach seems to be the main reason of the inconsistency of the recovery rates of the duplicates, especially for the mixed gravel simulators. Similar to previous results (Valencia et al., 2008) the leaching tests (Table 6) revealed that the residues did not comply with the FSQ status, comparable to the Waste Acceptance Criteria (WAC) for inert waste of the Landfill Directive (CEC, 2003). However, these results were close to compliance with such a stringent criterion in a shorter period of time. The residues did comply with alternative parameters used to define stability of waste residues such as low BMP $\left(<0.045 \mathrm{~m}^{3} \mathrm{~kg}^{-1} \mathrm{VS}\right)$, BOD/COD ratio $(<0.20)$, low VS content, a dark sludge-like appearance and low $(<0.1) \mathrm{SO}_{4}{ }^{2-} / \mathrm{Cl}^{-}$ratio (Lo, 1996; Reinhart and Townsend, 1998). In addition, heavy metal levels were several times lower than those stated in the regulation for exceptional quality compost of USEPA (Das et al., 2002). 

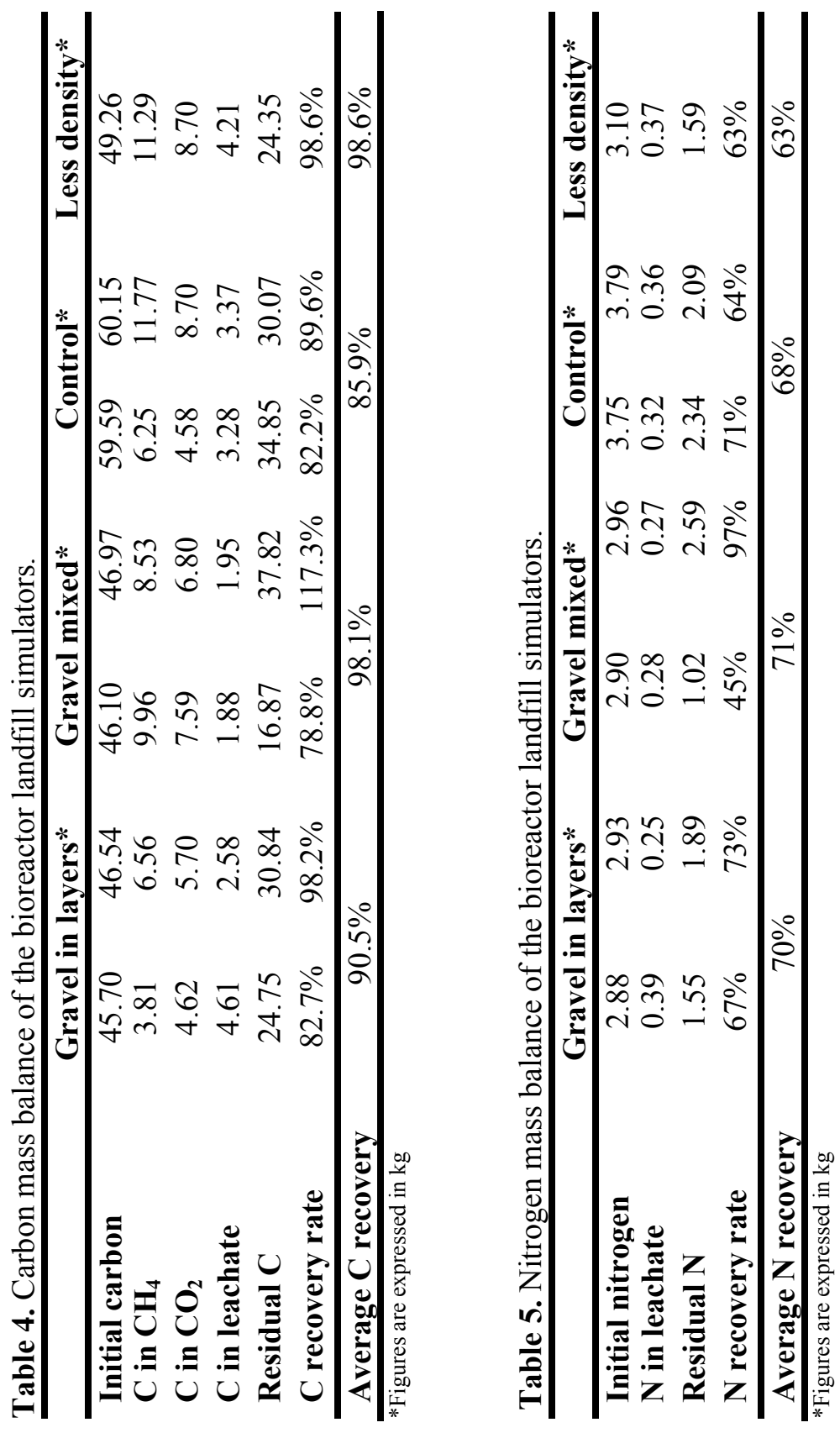


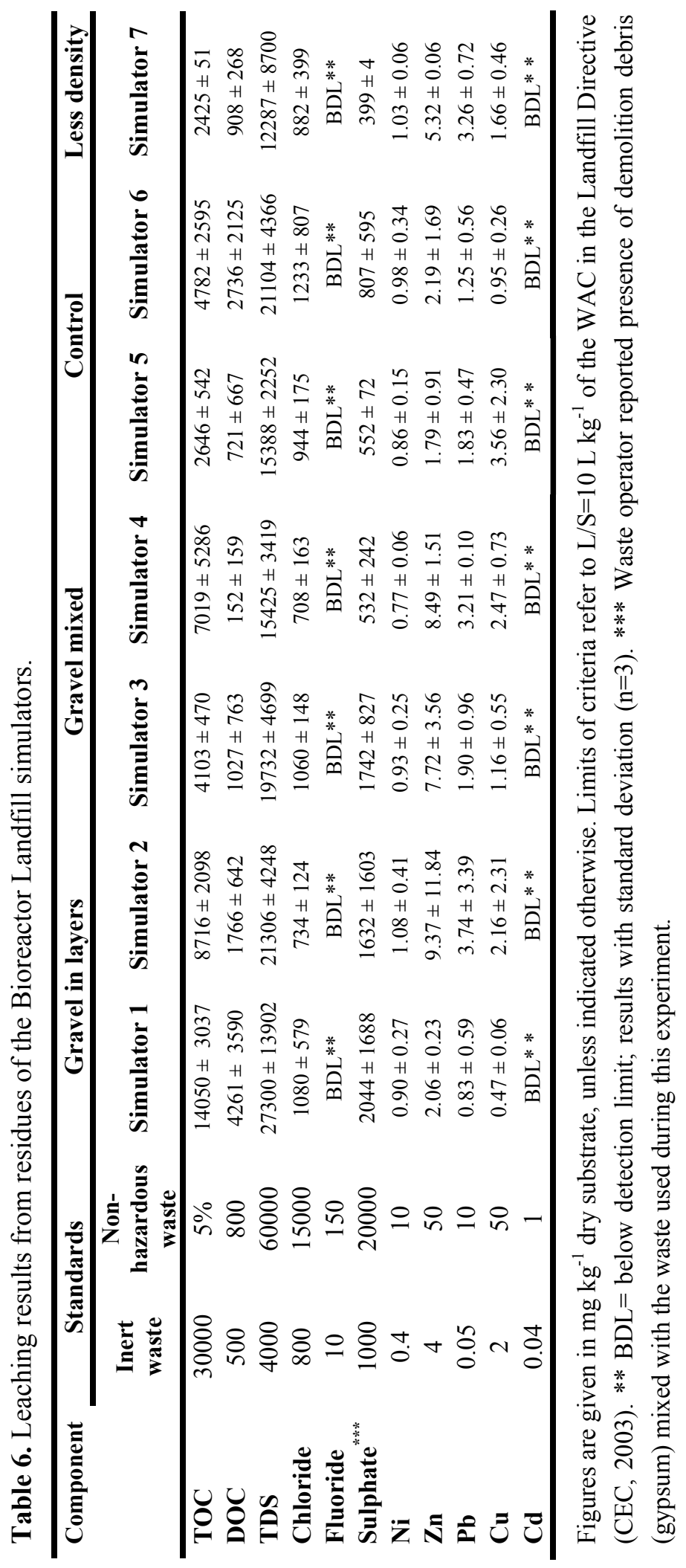




\subsection{The effect of the hydraulic conditions}

The control simulator with less density performed much better than the other simulators, probably because in the less density simulator there was less resistance for liquids and gases to flow in both directions. Nevertheless it was not clear if channelling did occur in the simulator. During the final sampling it was observed that most of the residue was converted into a "muddy-like" material and water. Similarly, in the simulators with gravel in layers, the same type of "muddy-like" material was found under the bottom layer of gravel. Apparently, the enhanced biodegradation of waste promotes a faster reduction of the waste particles, which in turn clog the available pores thus reducing the leachate recirculation efficiency of the simulators. This was clearly observed from day 250 onwards when it became more difficult to extract sufficient leachate for the recirculation process in all these simulators (less density and gravel in layers). In addition, this "muddy-like" material, which seemed to have a low hydraulic conductivity, restricted the passage of leachate since it kept the layers underneath relatively dryer than the rest of the residual material.

In contrast, the mixed gravel simulators were more effective by being able to absorb these temporal and spatial changes of the MSW particles, presumably helping to maintain the homogenised conditions as the waste stabilisation process proceeded. The fact that the hydraulic conditions were maintained may have helped to keep a constant flow of moisture, which in turn redistributed nutrients and micro-organisms within the simulators. This was inline with the findings of Elshorbagy and Mohamed (2000), who mixed several materials to improve the hydraulic conductivity of the composite material. In the mixed gravel simulators, it was observed that the leachate extraction process never reduced its flow velocity.

\section{References}

Ağdağ O.N., Sponza D.T. (2005). Effect of alkalinity on the performance of a simulated landfill bioreactor digesting organic solid wastes. Chemosphere, 59, 871-879

Allen A. (2001). Containment Landfills: the myth of sustainability. Eng. Geol. 60, 3-19. 
Al-Yousfi A.B., Pohland F.G. (1998). Strategies for simulation, design and management of soldi waste disposal sites as landfills bioreactors. Pract. Perio. Hazard. Toxic Radioact. Waste Mgmt. 2, 13-21.

APHA (2005). Standard Methods for Water and Wastewater Examination, 21st ed. American Public Health Association, Washington, DC.

Barlaz M.A., Ham R.K., Schaefer D.M. (1989). Mass-balance analysis of anaerobically decomposed refuse. J. Environ. Eng-ASCE.115, 1088-1101.

Bayer E.A., Lamed R., Himmel M.E. (2007). The potential of cellulases and cellulosomes for cellulosic waste management. Curr. Opin. Biotech. 18, 237-245.

Benson C.H., Barlaz M.A., Lane D.T., Rawe J.M. (2007). Practice review of five bioreactor/recirculation landfills. Waste Manage. 27, 13-29.

Berge N.D., Reinhart D.R., Townsend T.G. (2005). Fate of nitrogen in bioreactor landfills. Crit. Rev. Env. Sci. Technol. 35, 365-399.

Bilgili M.S., Demir A., Öskaya B. (2007). Influence of leachate recirculation on aerobic and anaerobic decomposition of solid wastes. J. Hazard. Mater. $143,177-183$.

CEC (2003). Council Decision 2003/33/EC of 19 December 2002, Establishing criteria and procedures for the acceptance of waste at landfills pursuant to Article 16 of and Annex II to Directive 1999/31/EC. Official Journal of the European Communities, 16.01.2003, L11/27- 49.

CEN (2002). NEN-EN 12457-4:2002en "Compliance test for leaching of granular waste materials and sludges - Part 4", available in http://www2.nen.nl.

Chen P.H. (1996). Assessment of leachates from sanitary landfills: impact of age, rainfall and treatment. Environ. Int. 22, 225-237.

Das K.C., Smith M.C., Gattie K.D., Hale-Boothe D.D. (2002). Stability and quality of municipal solid waste compost from a landfill aerobic bioreduction process. Adv. Environ. Res. 6, 401-409.

Davisson A., Gruvberger C., Christensen T.H., Lund T.H., Cour J.J. (2007). Methane yield in source-sorted organic fraction of municipal solid waste. Waste Manage. 27, 406-414.

Dinamarca S., Aroca G., Chamy R., Guerrero L. (2003). The influence of pH in the hydrolytic stage of anaerobic digestion of the organic fraction of urban solid waste. Water Sci. Technol. 48(6), 249-254. 
Elshorbagy W.A., Mohamed A.M.O. (2000). Evaluation of using municipal solid waste compost in landfill closure caps in arid areas. Waste Manage. 20, 499-507.

Evans G. (2001). Biowaste and biological waste treatment. James \& James Science Publishers, London U.K.

Gurijala K.R., Suflita J.M. (1993). Environmental factors influencing methanogenesis from refuse in landfill samples. Environ. Sci. Technol. 27, 1178-1181.

Hartz K.E., Klink R.E., Ham R.K. (1982). Temperature effects: methane generation from landfill samples. J. Environ. Eng-ASCE. 108, 629-638.

Haydar M.M., Khire M.V. (2005). Leachate recirculation using horizontal trenches in bioreactor landfills. J. Geotech. Geoenviron. 131, 837-847.

He P.J., Shao L.M., Qu X., Li G.J., Lee D.J. (2005). Effects of feed solutions on refuse hydrolysis and landfill leachate characteristics. Chemosphere, $59,837-844$.

Jang Y.C., Townsend T. (2001). Sulfate leaching from recovered construction and demolition debris fines. Adv. Environ. Res. 5, 203-217.

Jetten M., Strous M., van de Pas-Schoonen K., Schalk J., van Dongen U., van de Graaf A., Logemann S., Muyzer G., van Loosdrecht M., Kuenen J. (1998). The anaerobic oxidation of ammonium. FEMS Microbiol. Rev. 22, 421-437.

Khire M.V., Mukherjee M. (2007). Leachate injection using vertical wells in bioreactor landfills. Waste Manage. 27, 1233-1247.

Kim H., Townsend T. (2007). Evaluation of pressure treated wood impact on landfill waste decomposition using a methane yield assay. Chemosphere, $67,1252-1257$

Kim K.H., Choi Y.J., Heon E.C., Sunwoo Y. (2005). Characterization of malodorous sulfur compounds in landfill gas. Atmos. Environ. 39, 11031112

Kinman R.N., Nutini D.L., Walsh J. J., Vogt W.G., Stamm J., Rickabaugh J. (1987). Gas enhancement techniques in landfill simulators. Waste Manage. Res. 5: 13-25.

Kjeldsen P., Barlaz M.A., Rooker A.P., Baun A., Ledin A., Christensen T.H. (2002). Present and long-term composition of MSW landfill leachate: a review. Crit. Rev. Env. Sci. Technol. 32, 297-336.

Klink R.E., Ham R. (1982). Effects of moisture movement on methane production in solid waste landfill samples. Resour. Consev. 8, 29-41 
Leckie J.O., Pacey J.G., Halvadakis C. (1979). Landfill management with moisture control. J. Environ. Eng-ASCE. 105, 337-355.

Ledakowicz S., Kaczorek K. (2004). Laboratory simulation of anaerobic digestion of municipal solid waste. J. Environ. Sci. Heal. A. 39, 859-871.

Lens P.N.L., Visser A., Janssen A.J.H., Hulshoff Pol L.W., Lettinga G. (1998). Biotechnological treatment of sulfate-rich wastewaters. Crit. Rev. Env. Sci. Technol. 28, 41-88.

Lo I.M.-C. (1996). Characteristics and treatment of leachates from domestic landfills. Environ. Int. 22, 433-442.

McCreanor P.T., Reinhart D.R. (1999). Hydrodynamic modeling of leachate re-circulating landfills. Waste Manage. Res. 17, 465-469.

Mehta R., Barlaz M.A., Yazdani R., Augenstein D., Bryars M., Sinderson L. (2002). Refuse decomposition in the presence and absence of leachate recirculation. J. Environ. Eng-ASCE. 128, 228-236.

Miller D.E., Emge S.M. (1997). Enhancing landfill leachate recirculation system performance. Pract. Period. Hazard. Toxic Radioact. Waste Mgmt. 1, 113-119.

Morris J.W.F., Vasuki N.C., Baker J.A., Pendleton C.H. (2003) Findings from long-term monitoring studies at MSW landfill facilities with leachate recirculation. Waste Manage. 23, 656-666.

Parkhurst D.L., Appelo C.A.J., (1999). User's guide to PHREEQC (Version2) - a computer program for speciation, reaction-path, advectivetransport, and inverse geochemical calculations. USGS Water-Resources Investigation Report 99-4259.

Pohland F., Al-Yousfi B. (1994). Design and Operation of Landfills for Optimum Stabilization and Biogas Production. Water Sci. Technol. 30(12), 117-124.

Pohland F.G. (1996). Landfill Bioreactors: fundamentals and practice. Water Qual. Int. 9/10, 18-22.

Pohland F.G., Kim J.C. (1999). In situ anaerobic treatment of leachate in landfill bioreactors. Wat. Sci. Technol. 40(8), 203-210.

Reinhart D.R., Townsend T.G. (1998). Landfill bioreactor design \& operation. Lewis Publishers, New York, U.S.A.

Reinhart D.R., Al-Yousfi A.B. (1996). The impact of leachate recirculation on municipal solid waste landfill operating characteristics. Waste Manage. Res. 14, 337-346. 
Reinhart D.R., McCreanor P.T., Townsend T. (2002). The bioreactor landfill: Its status and future. Waste Manage. Res. 20, 172-186.

Rosqvist N.H., Destouni G. (2000). Solute transport through preferential pathways in municipal solid waste. J. Contam. Hydrol. 46, 39-60.

Rosqvist N.H., Dollar L.H., Fourie A.B. (2005). Preferential flow in municipal solid waste and implications for long-term leachate quality: valuation of laboratory-scale experiments. Waste Manage. Res. 23. 367380.

Schieder D., Quicker P., Schneider R., Winter H., Prechtl S., Faulstich M. (2003). Microbiological removal of hydrogen sulfide from biogas by means of a separate biofilter system: experience with technical operation. Water Sci. Technol. 48(4), 209-212.

Strous M., van Gerven E., Zheng P., Kienen J.G., Jetten M.S.M. (1997). Ammonium removal form concentrated waste streams with the anaerobic ammonium oxidation (anammox) process in different reactor configurations. Wat. Res. 31, 1955-1962.

Tchobanoglous G., Kreith F. (2002). Handbook of solid waste management. McGraw-Hill publishers, New York

Townsend T.G., Miller W.L., Lee H.J., Earle J.F.K. (1995). Leachaterecycle infiltration ponds. J. Environ. Eng-ASCE. 121, 465-470.

Valencia R., van der Zon W., Woelders, H., Lubberding H.J., Gijzen H.J. (2008). Achieving "Final Storage Quality” of municipal solid waste in pilot scale bioreactor landfills. Waste Manage. (2008) in press.

doi:10.1016/j.wasman.2008.02.008

van Niftrik L.A., Fuerst J.A., Damste J.S.S., Kuenen J.G., Jetten M.S.M., Strous M. (2004). The anammoxosome: an intracytoplasmic compartment in anammox bacteria. FEMS Microbiol. Lett. 233, 7-13.

Veeken A., Kalyuzhnyi S., Scharff H., Hamelers B. (2000). Effect of pH and VFA on hydrolysis of organic solid waste. J. Environ. Eng-ASCE. 126, 1076-1081.

Vroon R., Oonk H., Marwijk W.V. (1999). A laboratory scale exploration of the long-term behaviour of mechanically separated organic residue in a flushing bioreactor. Waste Manage. Res. 17, 527-534.

Warith M. (2002). Bioreactor Landfills: experimental and field results. Waste Manage. 22, 7-17. 
Warith M.A., Smolkin P.A., Caldwell J.G. (2001). Effect of leachate recirculation on enhancement of biological degradation of solid waste: case study. Pract. Period. Hazard. Toxic Radioact. Waste Mgmt. 5, 40-46. Wu C.C., Lee W.M.G. (2004). Control of vaporous naphthalene by scrubbing with surfactants. J. Environ. Eng-ASCE. 30, 276-281.

Yuen S.T.S., Wang Q.J., Styles J.R. (2001). Water balance comparison between a dry and a wet landfill a full-scale experiment. J. Hydrol. 251, $29-48$. 


\title{
5 \\ Chapter
}

\section{Ammonium release and Anammox as an option for its removal}

A discovery is said to be an accident meeting a prepared mind.

Albert Szent-Gyorgyi (1893 - 1986)

\begin{abstract}
Experiments carried out in bioreactor landfill simulators demonstrated that more than $40 \%$ of the total $\mathrm{N}$ was transferred into the liquid and gas phases during the incubation period of 380 days. Besides minimal contributions from other N-removal processes, Anammox bacteria were found to be active within the simulators. Anammox is considered to be an important contributor to remove $\mathrm{N}$ from the solid matrix. However, it was unclear how the necessary nitrite for Anammox metabolism was produced. Ammonium, an end product of protein degradation and important parameter to consider during landfill closure, tends to accumulate up to inhibitory levels in the leachate of landfills especially in landfills with leachate recirculation. Most efforts to remove ammonium from leachate have been focused on ex-situ and partial in-situ methods such as nitrification, denitrification and chemical precipitation. Nevertheless, little is known about the nature of residual nitrogen in the waste mass and possible mechanisms to remove it. Intrusion of small quantities of $\mathrm{O}_{2}$ is believed to be beneficial for the degradation process of MSW in bioreactor landfills but not sufficient to remove significant amounts of ammonium via nitrification. Volatilisation
\end{abstract}

Submitted for publication at Environmental Science \& Technology as: Ammonium release and Anammox as an option for its removal in bioreactor landfill simulators. Valencia R., van der Zon W., Woelders H., Lubberding H.J., Gijzen H.J. January 2008. 
and Anammox activity were the main $\mathrm{N}$ removal mechanisms in the simulators. The results of these experiments bring new insights on the behaviour, evolution and fate of nitrogen that may contribute to better $\mathrm{N}$ removal from solid waste in bioreactor landfill simulators.

\section{Introduction}

Operating landfills as bioreactors has gained a lot of attention in recent years due to shorter waste stabilisation periods, higher biogas production and recovery, reduced leachate organic strength and maximised waste settlement and volume recovery (Pohland, 1980; Warith, 2002). However, bioreactor landfills have also shown several constraints such as uneven moisture distribution (seepage and preferential flow), geotechnical stability (landslides) and accumulation of toxic compounds in the leachate (chloride, ammonium, etc.) (Price et al, 2003). Ammonium content of the leachate is an important parameter to consider during the safe closure of landfill sites (Burton and Watson-Craik, 1998; Barlaz et al., 2002). Ammonium, an end product of protein degradation (Jokela and Rintala, 2003; Berge et al., 2005), tends to accumulate since there are no removal mechanisms under strict anaerobic conditions, especially in the leachate of landfills with leachate recirculation (Onay and Pohland, 1998; Price et al., 2003). Most efforts to remove ammonium from landfills were focused on the leachate fraction via ex-situ methods such as nitrification/denitrification, precipitation and even irrigation schemes (Ohlinger et al., 1998, Jokela et al., 2002; Li and Zhao, 2003; Kurniawan et al., 2006). Different approaches suggested referred to promoting ex-situ nitrification and in-situ denitrification of the leachate to remove ammonium (He et al., 2007) or even complete in-situ removal of ammonium by dedicated nitrification and denitrification zones (Onay and Pohland, 1998; Shao et al., 2007). However, in-situ or partially in-situ approaches are likely to produce $\mathrm{NO}_{\mathrm{x}}$ and $\mathrm{N}_{2} \mathrm{O}$, which are significant pollutants for their contribution to climate change (Price et al., 2003). Despite all efforts to reduce the levels of ammonium from landfill leachate, little information is available about the origin, evolution and fate of ammonium in bioreactor landfills and especially about the residual nitrogen in the solid phase. Huber et al. (2004) suggested that approximately $4 \%$ of $\mathrm{N}$ leaves the landfill via the leachate pathway, while $96 \%$ of $\mathrm{N}$ remained in the landfill body. Therefore, the objective of this 
study was to investigate the mechanisms involved in the ammonium release from the solid phase into the liquid phase and possible in-situ removal mechanisms under anaerobic conditions in bioreactor landfills.

\section{Materials and methods}

\subsection{Experimental set-ups}

Pilot scale. - Seven bioreactor landfills were simulated using high density polyethylene (HDPE) sewage pipes $\left(0.75 \mathrm{~m}^{3}\right.$ working volume) Schematic views and photographs of the simulators can be seen in Annex 1. The simulators were filled with shredded (particle size max. $4 \mathrm{~cm}$ ) municipal solid waste (MSW), the composition of which is shown in Table 1; operational features of the simulators were described elsewhere (Valencia et al., 2008a, 2008b). Buffered tap water (124 L, $\left.0.1 \mathrm{M} \mathrm{NaHCO}_{3}^{-}\right)$was added to stimulate leaching conditions; the leachate was recycled 3 times per week $\left( \pm 60 \mathrm{~L} \mathrm{week}^{-1}\right)$ in order to maintain a dynamic leachate flow and at least $45 \%$ moisture content (field capacity) on a wet weight basis. Buffer ( $0.3 \mathrm{M}$ $\mathrm{NaHCO}_{3}{ }^{-}$) was added to the leachate prior to recycling during a period of 6 weeks (day 50-100) to reduce the negative impact of the VFA on the $\mathrm{pH}$. The internal temperature of the simulators was maintained within the range of $30 \pm 4^{\circ} \mathrm{C}$.

Laboratory scale.- 10 simulators of $1 \mathrm{~L}$ volume were filled with $300 \mathrm{~g}$ shredded MSW. Photographs of the simulators can be seen in Annex 1. 150 $\mathrm{ml}$ of tap water $\left(\mathrm{O}_{2}\right.$ free $)$ were added to increase the moisture content and stimulate leaching conditions; the leachate was collected at the bottom and recirculated to the top of the simulators 5 times per week $\left( \pm 0.15 \mathrm{~L} \mathrm{week}^{-1}\right)$. The simulators were placed in a controlled temperature room $\left(30 \pm 0.5^{\circ} \mathrm{C}\right)$. Biogas production was measured daily using the displacement method and production figures were corrected for temperature and pressure.

Anammox activity test.- Solid samples were taken from the $0.75 \mathrm{~m}^{3}$ simulators, after subjected to a leaching test according to CEN (2002), the biomass was concentrated by centrifugation (3000 rpm for $1 \mathrm{hr}$ ) and $10 \pm 0.5$ $\mathrm{g}$ were placed in $50 \mathrm{ml}$ butyl septa airtight bottles flushed with argon and incubated in a $37^{\circ} \mathrm{C}$ control room. Anammox bacteria were enriched using a 
buffer solution of hepes/bicarbonate (75/5 mM, pH 7.8), $5 \mathrm{mM} \mathrm{NaNO}$, 2.5 $\mathrm{mM}\left(\mathrm{NH}_{4}\right)_{2} \mathrm{SO}_{4}, 0.1 \mathrm{mM}$ hydrazine $\left(\mathrm{N}_{2} \mathrm{H}_{4} \cdot \mathrm{H}_{2} \mathrm{SO}_{4}\right)$ according to Strous et al. (1999).

Anammox identification in the residue was carried out using fluorescent in situ hybridasation (FISH) techniques employing the following probes: Pla46 for planctomycetales, AMX820 covering all Anammox organisms, specially Kuenenia sp. and Brocadia sp. and DHI820 for Anammoxoglobus sp. Probes and hybridisation procedures are described in Schmid et al. (2003) and Kartal et al. (2007).

The effects of different ammonium concentrations on the waste stabilisation process were investigated by carrying out methanogenic activity tests using $500 \mathrm{ml}$ butyl septa airtight bottles purged with $\mathrm{N}_{2}$ and seeded with $10 \mathrm{~g}$ of shredded MSW, $50 \mathrm{~g}$ of anaerobic sludge and $2 \mathrm{ml} \mathrm{L}^{-1}$ of macronutrients and buffer $\left(\mathrm{NaHCO}_{3}\right)$ solution and $1 \mathrm{ml} \mathrm{L}^{-1}$ of trace elements, according to Sanders et al. (2000). All runs were carried out in triplicate with a constant $\mathrm{pH}(7.6 \pm 0.2)$ and constant temperature $\left(30 \pm 0.5^{\circ} \mathrm{C}\right)$.

Table 1. Composition of the municipal solid waste.

\begin{tabular}{lc}
\hline Component & Percentage (wet weight) \\
\hline Organic undefined & 33.2 \\
Paper \& cardboard & 15.2 \\
Plastics & 3.7 \\
Glass & 13.6 \\
Ferrous metals / non-ferrous metals & 0.6 \\
Leather/rubber & 0.2 \\
Wood & 2.5 \\
Inert (>3.4 mm) & 13.7 \\
Inert (<3.4 mm) & 15.2 \\
Textiles & 2.1 \\
\hline
\end{tabular}

Source ESSENT Milieu 2006 at transfer station in Wijster, The Netherlands (Provided by H. Woelders)

\subsection{Analytical procedures}

Moisture and volatile solids content of the MSW were analysed according to Standard Methods (APHA, 2005). Additionally, a leaching test (NEN-EN 12457-4) was conducted in triplicate to determine the leaching potential of $\mathrm{COD}, \mathrm{BOD}, \mathrm{TOC}, \mathrm{NH}_{4}{ }^{+}$, selected ions $\left(\mathrm{Cl}^{-}, \mathrm{NO}_{3}{ }^{-}, \mathrm{PO}_{4}{ }^{3-}, \mathrm{SO}_{4}{ }^{2-}\right)$ 
and heavy metals $(\mathrm{Pb}, \mathrm{Ni}, \mathrm{Zn}, \mathrm{Cu}, \mathrm{Cd})$ from the solid waste according to European Standards (CEN, 2002). The elemental composition (CHNS) of the MSW was determined by flash combustion in a partial oxygen atmosphere using helium as carrier, at $1020^{\circ} \mathrm{C}$ with a Thermo Quest EA 1110 Interscience elemental analyser. Leachate samples were analysed for $\mathrm{pH}$, temperature, conductivity and oxygen with portable meters WTW $\mathrm{pH}$ 340, LF 340 and Oxi 345, respectively. $\mathrm{NH}_{4}{ }^{+}$and $\mathrm{NO}_{2}{ }^{-}$were analysed according to Standard Methods (APHA, 2005). TOC was determined using an OI Corporation TOC Analyser $\mathrm{M}-700 . \mathrm{NO}_{3}{ }^{-}$was analysed using an Ion Chromatography system DIONEX ICS-1000 attached with an automated sample injector DIONEX ASI-100. All liquid samples were filtered with glass fibre filters GF 52, Schleicher \& Schuell. Biogas composition $\left(\mathrm{CH}_{4}\right.$, $\mathrm{CO}_{2}$ and $\mathrm{O}_{2}$ ) was monitored using a Geotechnical Instruments GA25 portable gas extraction analyser.

\subsection{Statistical analyses}

The graphs were constructed using averaged (7 simulators) values of $\mathrm{pH}$, TOC, biogas production, ammonium and $\mathrm{N}$ content and complemented with standard deviation bars.

\section{Results}

\subsection{Bioreactor landfill simulators performance}

The process parameters of the bioreactor landfill simulators are shown in Figure 1a. More details on the reactor set up and operation are presented in Valencia et al. (2008a, 2008b). Due to the accumulation of hydrolytic products the $\mathrm{pH}$ decreased in the first months of operation, but increased as soon as a more acclimatised methanogenic population developed, which converted these hydrolytic products into biogas. Initially, due to a constant dissolution of salts into the leachate, conductivity increased sharply during the first two weeks, followed by a more gradual increase during the next 150 days after which it remained relatively constant up to day 250. Thereafter conductivity started to decrease due to degassing (i.e. $\mathrm{CO}_{2}$ escape into the biogas) and precipitation within the simulators towards the end of the experiment. 

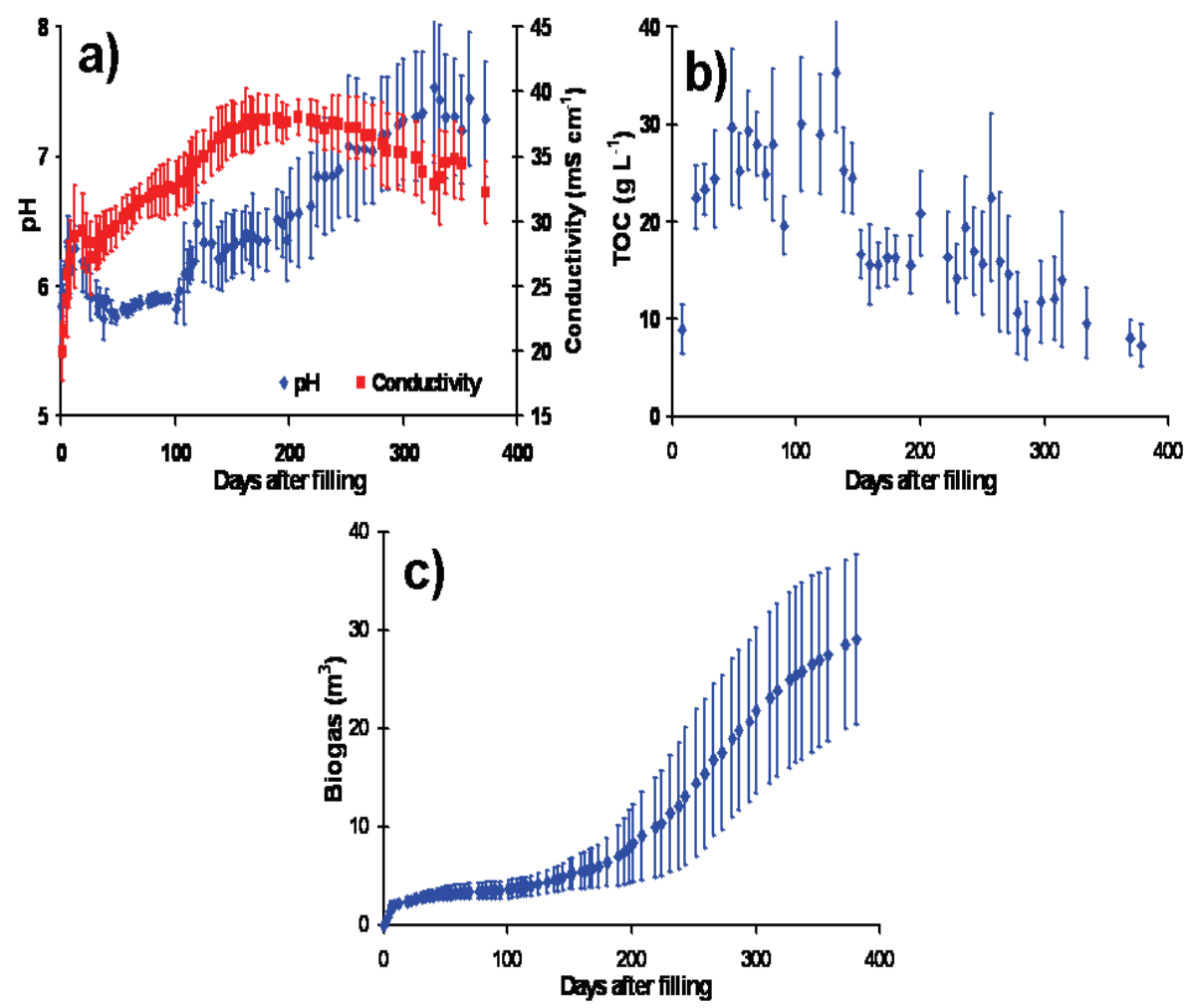

Figure 1. a) Conductivity and $\mathrm{pH}, \mathbf{b}) \mathrm{TOC}$ in the leachate and c) Cumulative biogas production from the bioreactor landfill

During the first 150 days of operation the biogas production (Fig. 1c) was minimal $\left(<5 \mathrm{~m}^{3}\right)$ and contained mainly $\mathrm{CO}_{2}( \pm 85 \%)$. However, as more favourable conditions (i.e. neutral $\mathrm{pH}$ ) for methanogens were reached, biogas production increased exponentially during the following 200 days, coinciding with a rapid decrease of TOC during the same period (Fig. 1b).

\subsection{Ammonium in the bioreactor landfill simulators}

After an initial increase of the ammonium levels (Fig. 2a) in the leachate during the first 100 days (up to $2.5 \mathrm{~g} \mathrm{~L}^{-1}$ ), ammonium concentration remained stable during the period between days 100 and 200. The fact that ammonium levels did not further increase could be caused by inhibitory levels of ammonium reached within the simulators, as shown by the methanogenic activity tests (Fig. 3b) at which ammonium levels above $2.5 \mathrm{~g}$ $\mathrm{NH}_{4}{ }^{+} \mathrm{L}^{-1}$ inhibited methane production. However, from day 200 onwards 
ammonium levels gradually started to decrease to an averaged $1.7 \mathrm{~g} \mathrm{~L}^{-1}$ (Fig. $2 \mathrm{a})$; the maximum ammonium decrease observed was about $1 \mathrm{~g} \mathrm{~L}^{-1}$. In a preliminary experiment with longer duration the same tendency was visible and the final ammonium levels were even below $1 \mathrm{~g} \mathrm{~L}^{-1}$ (Fig. 2b). After the ammonium levels started to decrease 2 simulators were aerated, this did not lead to a visible difference with the 5 non-aerated simulators (Fig. 2a).
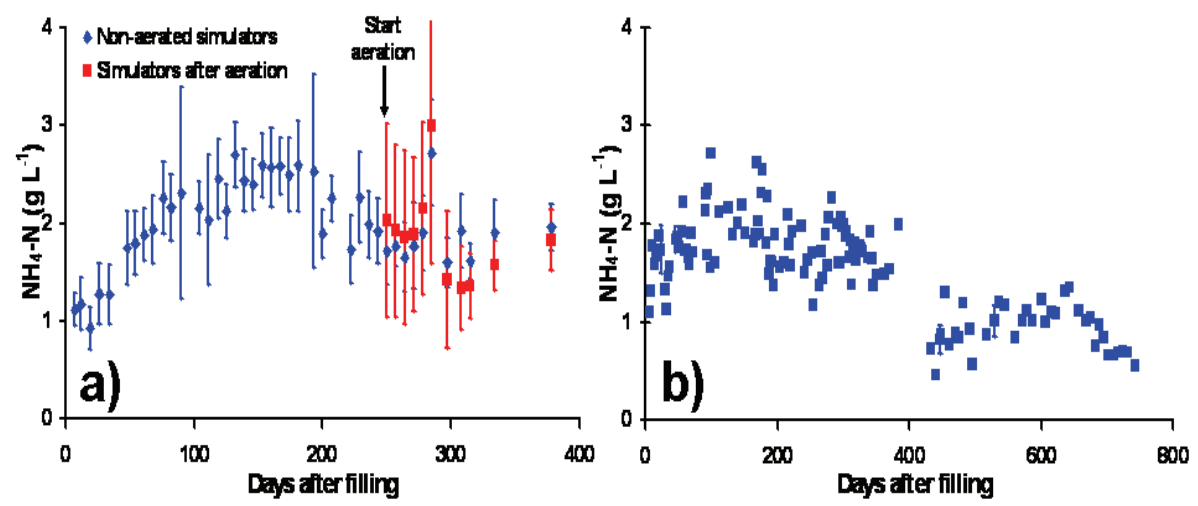

Figure 2. Ammonium in the leachate a) one year experiments with 7 simulators and b) two years experiments with 2 simulators preceding a).

The release of ammonium into the leachate seems to have two phases: a sharp increase to about $1 \mathrm{~g} \mathrm{~L}^{-1}$ within 6 to 10 days (up to $0.5 \mathrm{~g} \mathrm{~L}^{-1}$ in $24 \mathrm{hr}$ ) (Fig. 3a) and a gradual increase between day 10 and 100 up to $2.5 \mathrm{~g} \mathrm{~L}^{-1}$ (Fig. 2a).

A methanogenic activity tests showed different degrees of inhibition on the methane production at different ammonium levels at neutral $\mathrm{pH}$ and constant temperature of $30^{\circ} \mathrm{C}$ (Fig. 3b). 

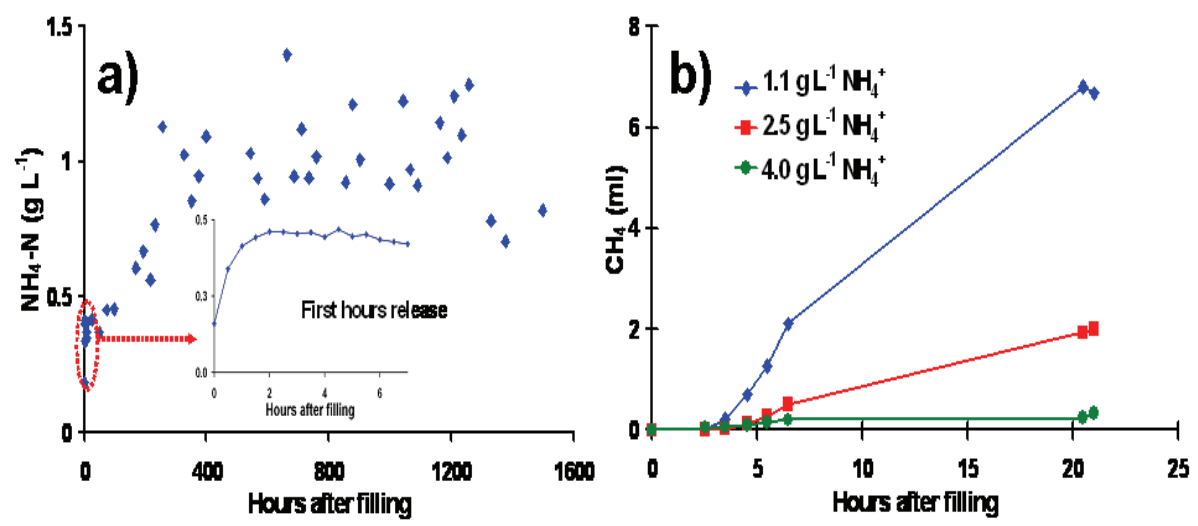

Figure 3. a) Initial ammonium release into the leachate in a bioreactor landfill simulator and $\mathbf{b}$ ) the effect of ammonium on methane production from MSW.

A possible explanation of the ammonium decrease (Fig. 2a-b) after day 200 could be the presence of Anammox bacteria. The samples taken on day 300 revealed the presence of Anammox bacteria (Fig. 4a-b). In addition high levels of hydrazine $\left(>6 \mathrm{mg} \mathrm{L}^{-1}\right)$, an intermediate product of the Anammox metabolism (Schmid et al., 2003; Kartal et al., 2007), were detected in the gas phase during the last 100 days of operation.

An activity test on the extracted biomass from the simulators showed patterns typical for Anammox bacteria: a 1:1 (1:0.98 this experiment) molar conversion of $\mathrm{NH}_{4}^{+}\left(0.0034\right.$ moles day $\left.{ }^{-1}\right)$ and $\mathrm{NO}_{2}^{-}\left(0.0046\right.$ moles day $\left.{ }^{-1}\right)$ accompanied with a minimal production of $\mathrm{NO}_{3}{ }^{-}$(Fig. $4 \mathrm{c}$ ). 


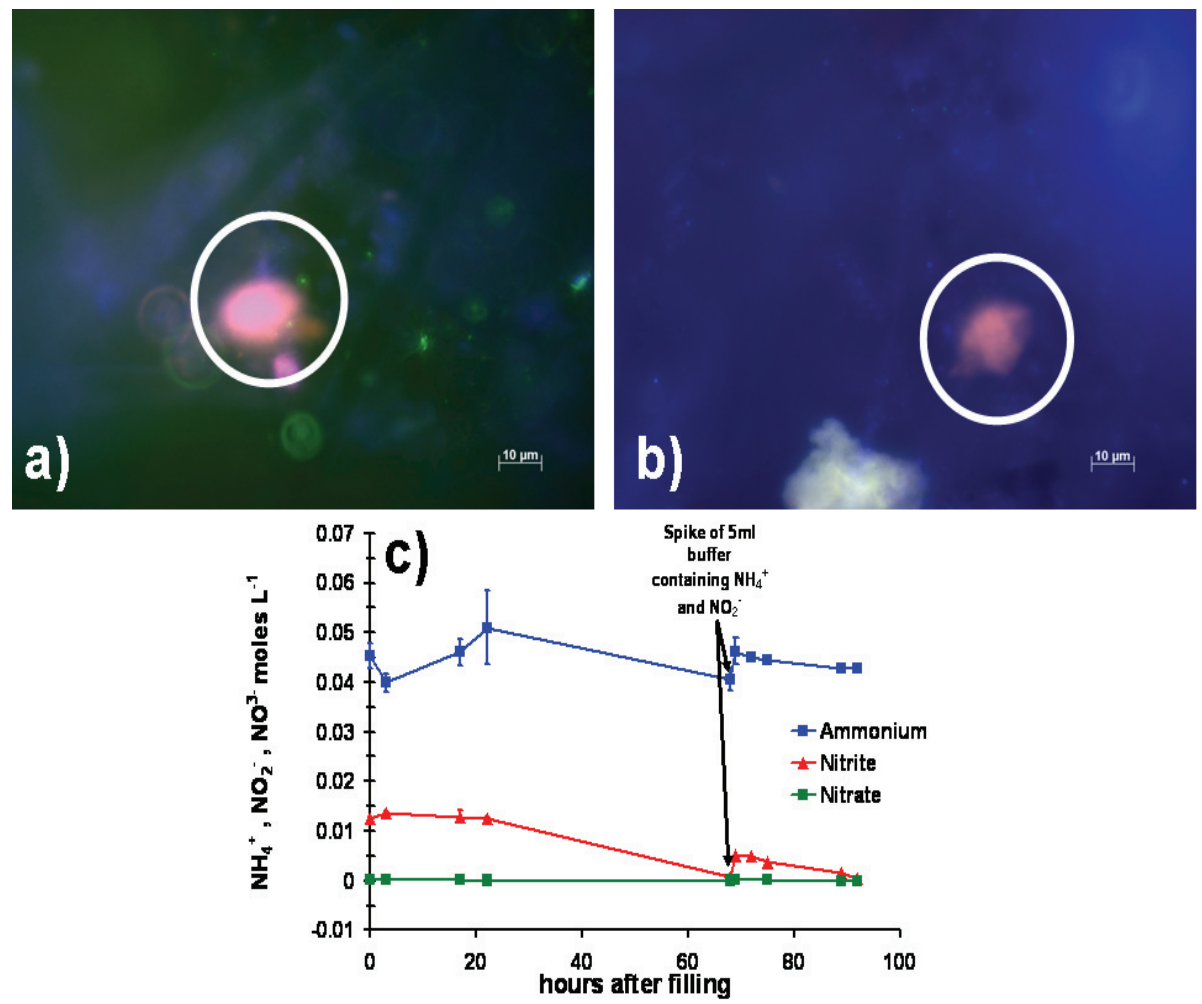

Figure 4. a-b) FISH analyses with PLA46, Amx820 and DHI820 probes (red Anammox clusters encircled) and c) Anammox activity test on biomass extracted from the bioreactor landfill simulators.

\section{Discussion}

The effectiveness of the simulators to transfer the carbon fraction from the solid phase into the liquid and gaseous phases has been previously described (Valencia et al., 2008a, 2008b). The biogas, pH, and TOC values followed similar trends as those reported in literature (Pohland, 1980; Warith, 2002) with faster responses in those simulators with improved hydraulic conditions (Valencia et al., 2008b).

The release of ammonium into the leachate during the first hours (up to $0.5 \mathrm{~g} \mathrm{~L}^{-1}$ ) (Fig. 3a inserted) seemed to be completely governed by a physical mechanism: the contact between solids and the liquid percolating through the waste mass. The subsequent increase of ammonium concentration (up to $1 \mathrm{~g} \mathrm{~L}^{-1}$ ) in the leachate during the first 6 to 10 days was due to the constant recirculation process, which helped to washout the 
ammonium salts present in the simulators. These ammonium salts could be produced during the initial 20-30 days at which waste was produced, stored, transported and samples were collected. During this period dry anaerobic and aerobic conditions caused ammonium salts to be "deposited" on the surface of the waste particles. The second ammonium increase from day 10 until day 100 (Fig. 2a-b) can be attributed to the enhanced microbiological conversion of organic matter under anaerobic conditions (Fig. 2a) (Berge et al., 2005; Jokela et al., 2005). Ammonium accumulated because there were no removal mechanisms within the simulators.

The results of the methanogenic activity tests (Fig. 3b) showed that at ammonium levels higher than $2.5 \mathrm{~g} \mathrm{~L}^{-1}$ the microbial activity started to decrease and/or cease, suggesting that concentrations of ammonium above this level are the threshold values for hydrolysis of organic matter, similarly to the values previously reported by Burton and Watson-Craik (1998) and Fricke et al. (2007). It is tempting to suggest that there is a steady state reached between day 100 and 200, where the constant ammonification rate is similar to the ammonium removal rate (Fig. 2a-b). The "accidental" intrusion of $\mathrm{O}_{2}\left(3.25 \mathrm{mg} \mathrm{O}_{2} \mathrm{~L}^{-1}\right.$ week $\left.{ }^{-1}\right)$ during the recirculation process $(60$ $\mathrm{L}_{\text {week }}{ }^{-1}$ ) was sufficient to carry-out partial or complete nitrification of the leachate and since during this period there was sufficient organic matter present in the simulators denitrification could also have taken place. Nitrification probably did not occur during the first 100 days, because nitrifying bacteria require more than 30 days to fully develop under optimal conditions (Hoilijoki et al., 2000). The fact that $\mathrm{NO}_{2}^{-}$and $\mathrm{NO}_{3}{ }^{-}$(data not shown) were not detected could mean two things: 1) Nitrification and subsequent denitrification were not taking place within the simulators, or 2) and more likely, the conversion rates of $\mathrm{NO}_{2}{ }^{-}$(and $\mathrm{NO}_{3}{ }^{-}$) into $\mathrm{N}_{2}$ occurred with a certain speed that these compounds could not be detected in the leachate. The ammonium trends (Fig. 2a-b) up to this point (day 200) were comparable to those reported in literature, especially those referring to large scale experiments (Morris et al., 2003).

The key factors for the decrease of ammonium levels after day 200 were, most likely, the reduced supply of ammonium as most of the readily organic matter (Fig. 1b) had been hydrolysed and started to be converted into biogas (Fig. 1c) and the constant recirculation process that kept supplying 
enough $\mathrm{O}_{2}$ to carry out, at least partial, nitrification of the leachate. Despite the fact that there was sufficient organic matter in the leachate (Fig. 1b) but probably not easily biodegradable, denitrification was limited as most of the acetic acid (data not shown), the preferred substrate by denitrifiers (Constantin and Fick, 1997) was depleted from the system. Consequently, from day 300 onwards minimal quantities of $\mathrm{NO}_{3}^{-}$(up to $30 \mathrm{mg} \mathrm{L}^{-1}$ ) (data not shown) started to be detected in the leachate, which suggests that denitrification and hence nitrification were also occurring at earlier stages within the simulators. However, calculations revealed that the amount of $\mathrm{O}_{2}$ introduced was not sufficient to reduce significantly ammonium levels. Therefore there must be other ammonium removal processes that have contributed to the decline in ammonium levels. This brought us to look for Anammox bacteria presence within the reactors. Similar decreases of ammonium levels has been observed and not fully explained in comparable bioreactor landfill experiments (Ağdağ and Sponza, 2005a, Ağdağ and Sponza, 2005b).

The biomass extracted from the simulators without active aeration revealed the presence of Anammox bacteria (Fig. 4a-b). The main species identified were Candidatus Brocadia anammoxidans, Candidatus Kuenenia stuttgartiensis and Candidatus Brocadia fulgida, with an estimated bacterial density of $5-7 \%$ of the total bacterial density (Schmid and op den Camp, 2007). It is more likely that partial nitrification up to $\mathrm{NO}_{2}^{-}$and sufficient ammonium in the leachate, supported by the optimal $\mathrm{pH}( \pm 7.5-8.0)$ and temperature $\left( \pm 30^{\circ} \mathrm{C}\right)$ (Strous et al., 1997), were the key factors for the development and activity of the Anammox bacteria within the simulators. At day 300, no Anammox bacteria were found in the two simulators which were intermittently aerated for about 50 days (240 L air week ${ }^{-1}$ ). Jetten et al. (1998) and Strous et al. (1999) reported that Anammox activity was reversible after exposure at low $\mathrm{O}_{2}$ concentrations, but, Egli et al. (2001) reported complete inhibition of Anammox activity at higher concentrations of $\mathrm{O}_{2}$, like the ones applied to these simulators. Besides the FISH analyses on the biomass and the presence of hydrazine, the activity test confirmed the presence of Anammox bacteria. The Anammox activity test results were similar to those reported by Egli et al. (2001) in which conversion of ammonium and nitrite were approximately 1:0.98 on molar basis, specially after spiking with a buffer solution containing $\mathrm{NH}_{4}^{+}$and $\mathrm{NO}_{2}^{-}$(Fig. 4c). 
Nitrogen balances (Fig. 5) showed that approximately $40 \%$ of the total $\mathrm{N}$ was released from the solid waste and transferred either into the liquid or the gas phase in a period of 380 days. At the end of the experimental period, only $2.3 \mathrm{~kg}$ of an initial $3.2 \mathrm{~kg}$ of $\mathrm{N}$ added to the simulators could be recovered: $1.9 \mathrm{~kg}$ as residual $\mathrm{N}$ and $0.4 \mathrm{~kg}$ of $\mathrm{N}$ in the free liquid mainly composed of ammonium $( \pm 80 \%)$ and $\mathrm{N}_{\text {org }}( \pm 20 \%)$. The unaccounted $\mathrm{N}$, if totally converted into $\mathrm{N}_{2}$, would had accounted for about $0.8 \mathrm{~m}^{3}$ of gas, which was approximately $2.8 \%$ of the total biogas production; this $\mathrm{N}_{2}$ value is within the ranges suggested in literature (Tchobanoglous and Kreith, 2002). It was not certain if the residual $\mathrm{N}$ was of inorganic and inert nature or perhaps was not biologically available in the form of humus-like material as suggested by Burton and Watson-Craik (1998).

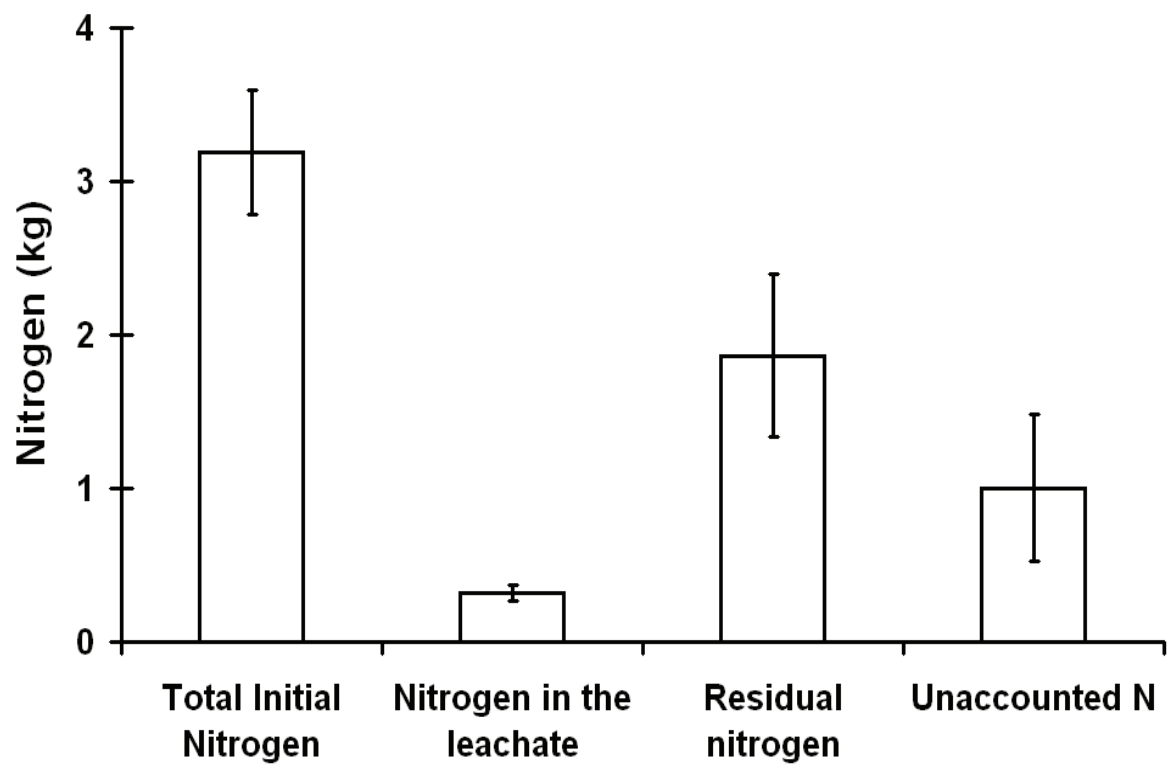

Figure 5. Nitrogen mass balance of the bioreactor landfill simulators.

Possible options to explain the amount of $\mathrm{N}$ removed $( \pm 1 \mathrm{~kg})$ from the simulators are: precipitation as struvite, volatilization of $\mathrm{NH}_{3}$, biological uptake, nitrification/denitrification and Anammox activity.

Theoretically, about $10 \mathrm{~g} \mathrm{~N}$ could be removed via struvite precipitation depending on $\mathrm{pH}$ values (above 7.5) and temperature (Ohlinger et al., 1998), since $\mathrm{NH}_{4}{ }^{+}, \mathrm{Mg}^{2+}$, and $\mathrm{PO}_{4}{ }^{3-}$ (33:6:1 molar ratio) exceeded the solubility values according to simulations using PHREEQC. However, struvite was not measured and most likely low $\mathrm{PO}_{4}{ }^{3-}$ concentrations (data not 
shown), instead of $\mathrm{Mg}^{2+}$, would be the limiting factor for precipitation of higher struvite quantities within the simulators.

Approximately $30 \mathrm{~g} \mathrm{~N}$ could have been volatilised as $\mathrm{NH}_{3}$ during the last 180 days according to $\mathrm{pH}$ values (maximal volatilisation rate $2.5 \%$ at $\mathrm{pH}=7.5 \pm 0.5)$.

Maximally $4 \mathrm{~g} \mathrm{~N}$ could have been used for assimilation by microorganisms for cell growth, similar to figures reported by Burton and Watson-Craik (1998); therefore bacterial up-take cannot explain the total consumption of $\mathrm{N}$ as suggested by Ağdağ and Sponza (2005a).

Removal of $\mathrm{N}$ due to full nitrification (up to $\mathrm{NO}_{3}{ }^{-}$) can only account for $2.3 \mathrm{~g} \mathrm{~N}$, considering that maximally $3.25 \mathrm{mg} \mathrm{O}_{2} \mathrm{~L}^{-1}$ were introduced every time the leachate was recycled into the simulators. Denitrification was not a limiting factor for $\mathrm{N}$ removal since there was sufficient organic matter present in the simulators at least during the first 200 days.

The combined effect of partial nitrification and Anammox, with the same amount of oxygen introduced, can stoichiometrically account for up to $5.4 \mathrm{~g}$ N removed. However, based on the approximated Anammox bacterial density and the removal yields suggested by Strous et al. (1997) it could be possible to explain the removal of the $93 \mathrm{~g} \mathrm{NH}_{4}{ }^{+}$. Moreover, the Anammox activity test results (Fig. 4c) suggested that it would have been possible to convert about $854 \mathrm{~g} \mathrm{~N}$, considering $100 \mathrm{~L}$ of free leachate and an active period from day 200 until day 380. However, it was not clear how the necessary $\mathrm{NO}_{2}^{-}$for Anammox was produced.

It is most likely that all these processes occurred simultaneously within the simulators. Anammox could be the main responsible factor for the removal of $\mathrm{N}$, especially when most of the readily organic matter was depleted (after day 200). However, Anammox bacteria depend on availability of $\mathrm{NO}_{2}^{-}$to carry out their metabolism, which can only be produced via nitrification; consequently the amount of $\mathrm{O}_{2}$ introduced would be the main limiting factor to remove ammonium as occurs in the CANON process for sewage treatment (Sliekers et al., 2002). Diffusion of $\mathrm{O}_{2}$ through the simulators walls was considered as a possibility, but it was unlikely since 
all reactors were operated at overpressure. Nevertheless according to HDPE properties (Composite Agency, 2007) maximally about $8.6 \mathrm{~g} \mathrm{O}_{2}$ could have penetrated through the wall during the entire length of the experiment (380 days), which was about $2.5 \%$ of the required $\mathrm{O}_{2}$ to nitrify the $93 \mathrm{~g} \mathrm{NH}_{4}^{+}$ converted during the experiment. Alternatively, $\mathrm{NO}_{2}^{-}$could have been produced externally in the leachate reservoirs and introduced via recirculation without being noticed. However, during incidental measurements in the leachate reservoirs $\mathrm{NO}_{2}{ }^{-}$was never detected. Anammox presence in landfill environments has been suspected before (Burton and Watson-Craik, 1998; Price et al., 2003; Berge et al., 2005), but never confirmed. To our knowledge these results present the first evidence of the existence of Anammox activity in bioreactor landfill simulators.

\section{References}

Ağdağ O.N., Sponza D.T. (2005a). Co-digestion of municipal sludge with municipal solid wastes in anaerobic simulated landfilling reactors. Process. Biochem. 40, 1871-1879.

Ağdağ O.N., Sponza D.T. (2005b). Effect of alkalinity on the performance of a simulated landfill bioreactor digesting organic solid wastes. Chemosphere. 59, 871-879

APHA (2005). Standard Methods for Water and Wastewater Examination, $21^{\text {st }}$ ed. American Public Health Association, Washington, DC.

Barlaz M.A., Rooker A.P., Kjeldsen P., Gabr M.A., Borden R.C. (2002). A critical evaluation of factors required to terminate the postclosure monitoring period at solid waste landfills. Environ. Sci. Technol. 36, 34573464.

Berge N.D., Reinhart D.R., Townsend T.G. (2005). Fate of nitrogen in bioreactor landfills. Crit. Rev. Env. Sci. Technol. 35, 365-399.

Burton S.A.Q., Watson-Craik I.A. (1998). Ammonia and nitrogen fluxes in landfill sites: applicability to sustainable landfilling. Waste Manag. Res. 16, 41-53.

CEN (2002). NEN-EN 12457-4:2002en "Compliance test for leaching of granular waste materials and sludges - Part 4", 2002. available in http://www2.nen.nl.

Composite Agency (2007). Analyses and simulation expertise, http://www.composite-agency.com/gas_diffusion.htm 
Constantin H., Fick M. (1997). Influence of C-sources on the denitrification rate of a high-nitrate concentrated industrial wastewater. Water Res. 31, 583-589.

Egli K., Fanger U., Alvarez P.J.J., Siegrist H., Van der Meer J.R,. Zehnder A.J.B. (2001). Enrichment and characterization of an anammox bacterium form a rotating biological contactor treating ammonium-rich leachate. Arch. Microbiol. 175, 198-207.

Fricke K., Santen H., Wallmann R., Hüttner A., Dichtl N. (2007). Operating problems in anaerobic digestion plants resulting from nitrogen in MSW. Waste Manage. 27, 30-43.

He R., Liu X.-W., Zhang Z.-J., Shen D.-S. (2007). Characteristics of the bioreactor landfill system using an anaerobic-aerobic process for nitrogen removal. Bioresour. Technol. 98, 2526-2532.

Hoilijoki H.T., Kettunen H.R., Rintala J.A. (2000). Nitrification of anaerobically pretreated municipal landfill leachate at low temperature. Water Res. 31, 1435-1446.

Huber R., Fellner J., Döeberl G., Brunner P. (2004). Water flows of MSW landfills and implications for long-term emissions. J. Environ. Sci. Health. A39, 885-900.

Jetten M.S.M., Strous M., van de Pas-Schoonen K., Schalk J., van Dongen U.G.J.M., van der Graaf A.A., Logemann S., Muyzer G., van Loosdrecht M.C.M., Kuenen J.G. (1998). The anaerobic oxidation of ammonium. FEMS Microbiol. Rev. 22, 421-437

Jokela J.P.Y., Kuttunen R.H., Sormunen K.M., Rintala J.A. (2002). Biological nitrogen removal from municipal landfill leachate: low-cost nitrification in biofilters and laboratory scale in-situ denitrification. Water Res. 36, 4079-4087.

Jokela J.P.Y., Rintala J.A. (2003). Anaerobic solubilisation of nitrogen from municipal solid waste. Rev. Environ. Sci. Biotechnol. 2, 67-77.

Jokela J.P.Y., Vavilin V.A., Rintala J.A. (2005). Hydrolysis rates, methane production and nitrogen solubilisation of grey waste components during anaerobic degradation. Bioresour. Technol. 96, 501-508.

Kartal B., Rattray J., Van Niftrik L.A., Van de Vossenberg J., Schmid M.C., Webb R.I., Schouten S., Fuerts J.A., Sinninghe Damsté J.S., Jetten M.S.M., Strous M. (2007). Candidatus “Anammoxoglobus propionicus” a new propionate oxidizing species of anaerobic ammonium oxidizing bacteria. System. Appl. Microbiol. 30, 39-49. 
Kurniawan T.A., Lo W.H., Chan G.Y.S. (2006). Physico-chemical treatments for removal of recalcitrant contaminants from landfill leachate. J. Hazard. Mater. B129, 80-100.

Li X.Z, Zhao Q.L. (2003). Recovery of ammonium-nitrogen from landfill leachate as a multinutrient fertilizer. Ecol. Eng. 20, 171-181.

Morris J.W.F., Vasuki N.C., Baker J.A., Pendleton C.H. (2003). Findings from long-term monitoring studies at MSW landfill facilities with leachate recirculation. Waste Manage. 23, 653-666.

Ohlinger K.N., Young T.M., Schroeder E.D. (1998). Predicting struvite formation in digestion. Water Res. 32, 3607-3614.

Onay T.T., Pohland F.G. (1998). In situ nitrogen management in controlled bioreactor landfills. Water Res. 32, 1383-1392.

Pohland F.G. (1980). Leachate recycle as landfill management option. $J$. Environ. Eng-ASCE 106(EE6), 1057-1069

Price A.G., Barlaz M.A., Hater G. R. (2003). Nitrogen management in bioreactor landfills. Waste Manage. 23, 675-688.

Sanders W.T.M., Geerink M., Zeeman G., Lettinga G. (2000). Anaerobic hydrolysis kinetics of particulate substrates. Water Sci. Technol. 41(3), 1724.

Schmid M., op den Camp H. (2007). Personal communication.

Schmid M., Walsh K., Weeb R., Rijpstra W.I.C., van de Pas-Schoonen K., Verbruggen M.J., Hill T., Moffett B., Fuerts J., Schouten S., Sinninghe Damsté J.S., Harris J., Shaw P., Jetten M.S.M., Strous M. (2003). Candidatus "Scalindua brodae", sp. nov., Candidatus "Scalindua wagneri", sp. nov., two new species of anaerobic ammonium oxidising bacteria. System. Appl. Microbiol. 26, 529-538.

Shao L.-M., He P.-J., Li G.-J. (2007). In situ nitrogen removal from leachate by bioreactor landfill with limited aeration. Waste Manage. 2007, DOI:10.1016/j.wasman.2007.02.028

Sliekers O.A., Derwort N., Campos J.L.G., Strous M., Kuenen J.G., Jetten M.S.M. (2002). Completely autotrophic nitrogen removal over nitrite in one single reactor. Water Res. 36, 2475-2482.

Strous M., Kuenen J.G., Jetten M.S.M. (1999). The key physiological parameters of the anaerobic ammonium oxidation process. Appl. Environ. Microbiol. 65, 3248-3250.

Strous M., van Gerven E., Zheng P., Kuenen J.G., Jetten M.S.M. (1997). Ammonium removal from concentrated waste streams with the anaerobic 
ammonium oxidation (Anammox) process in different reactor configurations. Water Res. 31, 1955-1962.

Tchobanoglous G., Kreith F. (2002). Handbook of solid waste management. McGraw-Hill publishers, New York.

Valencia R., van der Zon W., Woelders H., Lubberding H.J., Gijzen H.J. (2008a). Achieving "Final Storage Quality" of municipal solid waste in pilot scale bioreactor landfills. Waste Manage (2008) in press. DOI:10.1016/j.wasman.2008.02.008

Valencia R., van der Zon W., Woelders H., Lubberding H.J., Gijzen H.J. (2008b). The effect of hydraulic conditions on waste stabilization on Bioreactor Landfill simulators. Accepted for publication at Bioresource Technol.

Warith M. (2002). Bioreactor Landfills: experimental and field results. Waste Manage. 22, 7-17. 



\title{
Chapter
}

6

Mathematical simulations of carbon and nitrogen transformations in bioreactor landfill simulators

As far as the laws of mathematics refer to reality, they are not certain, and as far as they are certain, they do not refer to reality.

Albert Einstein (1879-1955)

\begin{abstract}
Biogas production, $\mathrm{pH}$ and ammonium evolution of seven bioreactor landfills was simulated using the LDAT (Landfill Degradation and Transport) model, developed by the University of Southampton, UK. The LDAT model was able to describe relatively accurately the processes occurring in Compression Anaerobic Reactors (CARs). However, LDAT was not able to simulate the processes occurring in the bioreactor landfill simulators. Main reasons for the discrepancy of the simulations are related to problems in the model construction, namely the biological and chemical reactions and the fact that $\mathrm{LDAT}$ operates at $20^{\circ} \mathrm{C}$. In addition inhibition factors such as sulphate (competition and its end-product $\mathrm{H}_{2} \mathrm{~S}$ ) and ammonium inhibition were not included in LDAT. A literature review on mathematical models for waste degradation revealed that ionic balances used were not complete, which has a significant influence on the buffer capacity of the landfill system. These findings suggest that in order to increase accuracy and applicability of these models, complete leachate chemistry (ionic balance) should be used as an important factor determining the rate at which biological and chemical reactions occur in the (bioreactor) landfills. Moreover, these findings highlight the importance of inorganic chemistry measurements in order to complement available data sets and reduce the
\end{abstract}


number of uncertainties during mathematical simulation of waste degradation in landfills.

\section{Introduction}

Operating landfill sites as bioreactors, the so-called bioreactor landfill approach, is gaining popularity among landfill operators due to the enhanced landfill gas production that can be used for energy purposes if properly captured (Pohland, 1980, 1996; Reinhart and Townsend, 1998). Additional benefits are: the gain of landfill volume and the reduction of the leachate chemical and biological strength (Morris et al., 2003; Benson et al., 2007). Substantial research has been conducted during the last three decades using laboratory and pilot-scale experiments from which it has been possible to identify the optimal ranges of the key process parameters namely $\mathrm{pH}$, temperature, moisture content, inhibitory content, diverse microbial kinetics, etc. (Gurijala and Suflita, 1993; Barlaz and Ham, 1993). Several municipalities, especially in United States of America, have adopted the bioreactor approach at full-scale. However, despite all positive feedback, no concrete conclusions about their effectiveness can be drawn at this point since most of these sites are still under scrutiny and monitoring periods are expecting to be completed in a period of five years from 2007 (Morris et al., 2003; Benson et al., 2007). This physical experimentation is essential and valuable to acquire knowledge but requires time and intensive labour input, which is reflected in the large amounts of financial resources being expended on it, especially when full-scale testing is required. Mathematical modelling, a less expensive and time consuming activity, of different scenarios could provide valuable insight of the diverse processes occurring within the landfill, and the possible effects of alterations in operation and/or environmental conditions can be processed quickly. Moreover, the results of modelling could help to improve designs and during the decision-making processes for a full-scale implementation of the best-case scenario.

Modelling all the physical, chemical and biological processes occurring within the landfill environment is a complex task, especially because not all variables are known until now. Assumptions have to be made to simplify these complex processes in order to describe them, relatively accurately, in mathematical terms (van Dam, 2005). There is enough literature available regarding modelling of the diverse landfill processes such 
as landfill gas and leachate production, waste mechanics (settlement and compaction), landfill hydrodynamics (water infiltration, channelling), landfill microbial interactions (kinetics) (El-Fadel and Khoury, 2000; Hudson et al., 2004; McGreanor and Reinhart, 2000; Ozkaya et al., 2006; Vavilin et al., 2003; Zacharof and Butler, 2004; Haarstrick et al., 2001, 2004; White et al., 2003, 2004). However, few authors have incorporated all variables or processes in their proposed models and even fewer have validated their models with, the scarce and not completely reliable, full-scale data.

The LDAT (Landfill Degradation and Transport) model, developed by the University of Southampton, attempts to incorporate microbial kinetics of leachate and gas production and their transport in addition to the consolidation of the solid waste (White et al., 2003, 2004). LDAT describes the processes occurring in fully saturated consolidating anaerobic reactors (CARs) which were subjected to compression and up-flow liquid recirculation (Ivanova et al., 2003). In this thesis, despite the different operational mode, the LDAT model was used to simulate the biogas production, $\mathrm{pH}$ and ammonium evolution of seven non-saturated bioreactor landfills with down-flow pattern leachate recirculation.

\section{Materials and Methods}

\subsection{Experimental set-up and data}

Data for simulations were collected from seven active bioreactor landfill simulators of $0.8 \mathrm{~m}^{3}$ filled with approximately $350 \mathrm{~kg}$ of municipal solid waste (MSW) operated for a period of 1 year. The simulators were constantly monitored for biogas production, $\mathrm{pH}$, carbon (COD, BOD and TOC) and nitrogen $\left(\mathrm{NH}_{4}^{+}, \mathrm{NO}_{3}^{-}\right)$among other parameters. More details of the operational features of the simulators and the analytical procedures performed are presented in Valencia et al. (2008a, 2008b) and in the previous chapters (Chapter $4 \& 5$ ). The MSW placed in the simulators was collected and characterised at the transfer station of Wijster, The Netherlands as shown in Table 1. 
Table 1. Composition of the municipal solid waste.

\begin{tabular}{lc}
\hline Component & Percentage (wet weight) \\
\hline Organic undefined & 33.2 \\
Paper \& cardboard & 15.2 \\
Plastics & 3.7 \\
Glass & 13.6 \\
Ferrous metals / non-ferrous metals & 0.6 \\
Leather/rubber & 0.2 \\
Wood & 2.5 \\
Inert (>3.4 mm) & 13.7 \\
Inert (<3.4 mm) & 15.2 \\
Textiles & 2.1 \\
\hline
\end{tabular}

Source: ESSENT Milieu 2006 at transfer station in Wijster, The Netherlands (Provided by H.Woelders)

\subsection{LDAT model construction}

The LDAT model integrates several sub-models (degradation, settlement, changes in waste structure, leachate and gas generation and flow) in order to simulate all the spatially distributed processes occurring in a landfill. The degradation sub-model is based on the model proposed by ElFadel et al. (1996) in which solids are dissolved into the leachate by enzymatic hydrolysis and solution, and then converted into gas by the present microbial communities. However, LDAT includes a lytic biomass control for the initial hydrolytic degradation of solids, thus modifying the ElFadel et al. (1996) model. The rate of degradation is governed by the metabolic activity of three microbial groups present (lytic, acidogenic and methanogenic) as function of the available carbon present. The chemistry and stoichiometric equations are based on those proposed by Young (1989). An important aspect of LDAT is the incorporation of a $\mathrm{pH}$ inhibition function (Equation 1) that affects the biomass growth rates, thus the biogas production.

$\mathrm{pH}=\mathrm{A} \cdot p A+\mathrm{n}$

Where $\mathrm{A}$ and $\mathrm{n}$ are inhibition constants for acidity and buffering and $p A$ is the logarithmic relation (Equation 2) of the acetic acid and the acids in solution (White et al., 2003).

$p A=-\log _{10}\left(A_{c}+A_{q}\right)$ 
Another important aspect of LDAT is the possibility to discriminate between readily, moderately and hardly biodegradable organic substrates as input parameters, reflecting the reality of MSW in landfills.

Nevertheless, LDAT suffers from the inability to vary dynamically the microbiological parameters (growth, maintenance and death rates) as function of the available substrates and possible inhibitory substances (dissolved cations and ions). Probably the main limitation of the model is that LDAT runs at a constant temperature of $20^{\circ} \mathrm{C}$. More detailed information about the LDAT model construction can be found in White et al. (2003, 2004).

\section{Results and discussion}

\subsection{LDAT sensitivity analysis}

A sensitivity analysis of the input parameters revealed that the LDAT model is most sensitive to biological and environmental parameters, especially lytic and methanogenic bacterial growth rates and $\mathrm{pH}$ inhibition factors. Nevertheless, the model is not sensitive for growth rates higher than 0.2 day $^{-1}$. LDAT model did not exhibit significant influence from physical parameters such as the organic content of the waste or temperature. Varying the catalytic factors and moisture content did not vary significantly the amount of biogas or solids transformed during the simulations. Regarding temperature, it is important to remark that LDAT model assumes a constant temperature of $20^{\circ} \mathrm{C}$ (White et al., 2005), which as mentioned before is the main limitation of the model. Therefore, based on the sensitivity analysis, the following input parameters were used in the simulations (Table 2). The best-fit parameters such as bacterial growth rates were higher than the values reported by White et al. $(2003,2005)$. However, bacterial growth rate values were lower than the values used by Reichel et al. (2007) which simulate, with a more accurate model, the same waste and reactors used by White et al. $(2003,2005)$. These best-fit parameters were determined after 31 simulations with LDAT; the best 5 simulations (Simulations 25, 28, 29, 30 and 31 ) are reported here. 
Table 2. Best input parameters based on the sensitivity analysis.

\begin{tabular}{lll}
\hline Parameter & Value / range & Best fit \\
\hline Lytic bacteria growth rate & $0.12-0.20$ day $^{-1}$ & 0.15 day $^{-1}$ \\
Methanogenic bacteria growth rate & $0.12-0.20$ day $^{-1}$ & 0.1655 day $^{-1}$ \\
pH inhibition coefficient A (Eq. 1 acidity) & $0.25-0.35$ & 0.305 \\
pH inhibition coefficient n (Eq. 1 buffer) & $5.1-5.4$ & 5.325 \\
\hline
\end{tabular}

\subsection{LDAT biogas production}

The simulations showed a discrepancy between the actual amount of biogas produced and the predicted model results (Fig. 1). In addition, all model results exhibited a different trend when compared to the average biogas production. LDAT biogas production increased exponentially earlier than the experimental results (simulations 25-29). This was attributed to higher bacterial growth rates $\left(0.20\right.$ day $\left.^{-1}\right)$ and higher $\mathrm{pH}$ inhibition $(\mathrm{A}=0.35$, $\mathrm{n}=5.4$ ) coefficients used during the simulations.

More accurate results were obtained during simulations 30 and 31, especially after day 200; however, $\mathrm{pH}$ model results (Fig. 2) diverted significantly from the experimental results. Lower bacterial growth rates $\left(0.12\right.$ day $\left.^{-1}\right)$ and $\mathrm{pH}$ inhibition factors $(\mathrm{A}=0.30, \mathrm{n}=5.25)$ were used during these simulations. The LDAT model not only overestimates the total biogas production but also the composition of the biogas, reporting a $30 \% \mathrm{CH}_{4}$ and $70 \% \mathrm{CO}_{2}$, whereas the experimental results showed a biogas composition of $56 \% \mathrm{CH}_{4}, 43 \% \mathrm{CO}_{2}$ and $0.5 \% \mathrm{O}_{2}$. This was attributed to the chemistry of solids degradation described in the model (White et al. 2003, 2004) in which $\mathrm{CO}_{2}: \mathrm{CH}_{4}$ (27:73) ratio was fixed at around unity by volume, giving a poor fit for the individual $\mathrm{CH}_{4}$ and $\mathrm{CO}_{2}$ cumulative gas generation. 


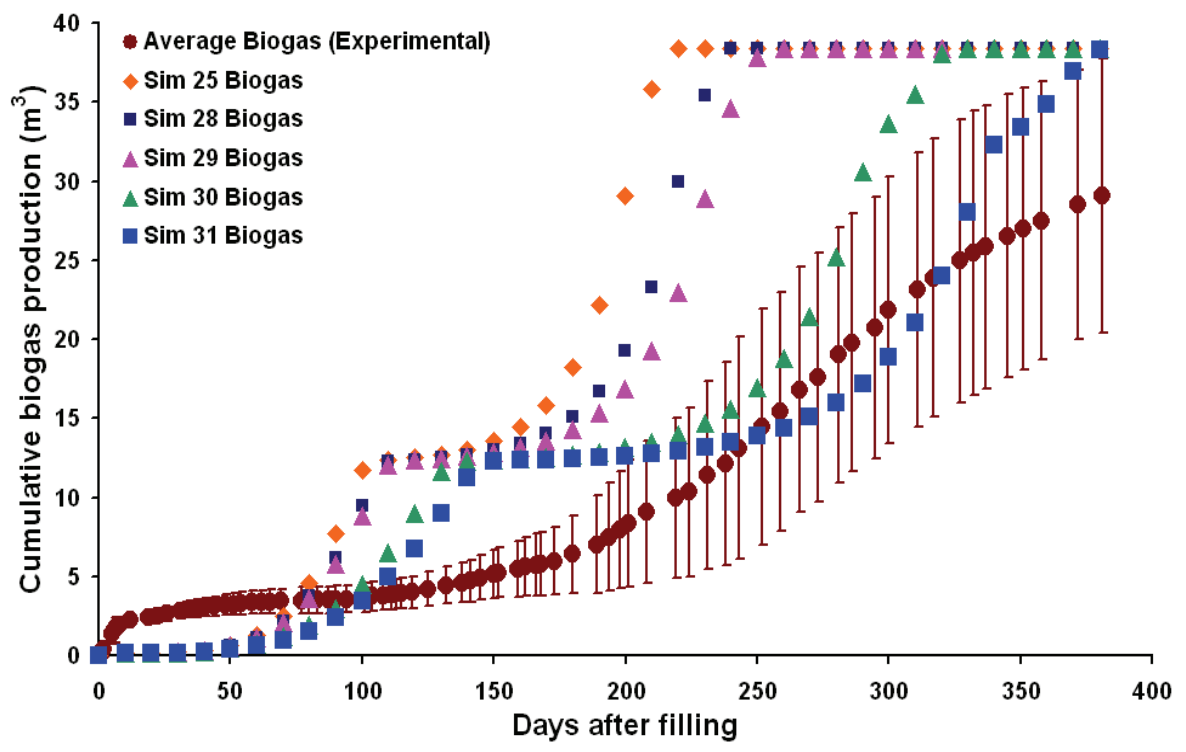

Figure 1. Measured vs. model cumulative biogas production.

\section{$3.3 \quad$ LDAT pH}

The model predicted similar $\mathrm{pH}$ values to those measured during the experiment for the first 50 days (Fig. 2), as the amount of acids dissolved into the leachate caused $\mathrm{pH}$ values to decrease. However, model predictions differ considerably after day 50 , when the leachate was buffered prior to recirculation. This buffering campaign was implemented in order to avoid $\mathrm{pH}$ suppression due to excessive accumulation of VFA within the system (Valencia et al., 2008b). It would be reasonable to argue that the discrepancy of results was due to the buffer added. However, a previous experiment (Valencia et al., 2008a) in which leachate was not buffered exhibited a different pattern than the simulations. Therefore, it is clear that there is a different description, between LDAT and the simulators, of the buffering capacity where bicarbonate could be expected to be the main contributor (Reinhart and Al-Yousfi, 1996; Ağdağ and Sponza, 2005).

The buffering capacity of the simulators (experiments) was maintained artificially by two processes: addition of buffer to the leachate and the slow but constant development of methanogens, which removed VFA (acidity) from the system. This allowed more bicarbonate to be present in solution to buffer the simulators. In contrast according to the model, the 
buffer capacity was exceeded because acids were constantly dissolved into the leachate causing $\mathrm{pH}$ to decrease below 5.5. The simulations showed that the available organic matter was dissolved into the leachate after 100 to 150 days. Since no more acids were dissolved and LDAT methanogens started to convert VFA into biogas, the bicarbonate equilibrium of the model started to buffer the system, consequently increasing $\mathrm{pH}$ values.

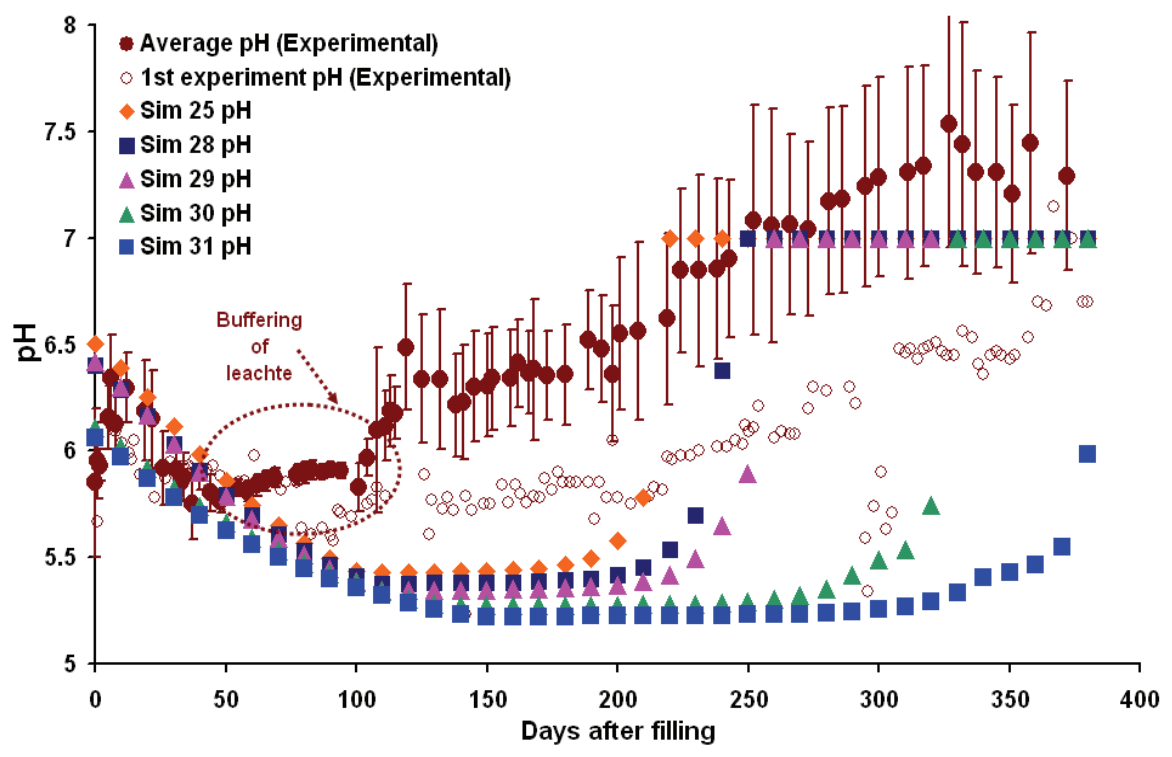

Figure 2. Measured vs. model $\mathrm{pH}$ of the leachate.

Apparently, in LDAT pH levels below 5.5 (Fig. 2) inhibited biogas production during the period between day 100 and 200 (Fig. 1). As soon as $\mathrm{pH}$ levels were above this threshold level, biogas production was resumed. It seems that LDAT ionic balance calculates, based on the amount of acids dissolved, a $\mathrm{pH}$ value, which in turn dictates the development of the bacterial groups (acidogens and methanogens) responsible for the transformation of these intermediate products (VFAs) into biogas. In addition, LDAT does not consider the contribution of the early biogas production to the buffer capacity (first 50 days, Figure 1) before the system inhibits itself due to the accumulation of VFA. The simulation results also showed that $\mathrm{pH}$ values did not increase above 7 . This was because LDAT model does not consider other dissolved species $\left(\mathrm{NH}_{4}^{+}, \mathrm{Cl}^{-}, \mathrm{PO}_{4}{ }^{3-}, \mathrm{Na}^{+}, \mathrm{K}^{+}\right.$, etc.) than bicarbonate that can contribute to increase $\mathrm{pH}$ levels. This has been previously addressed by White et al (2005). Higher $\mathrm{pH}$ levels were reached $( \pm 8)$ when higher 
inhibition coefficients and higher initial $\mathrm{pH}$ values were used. However, biogas production in reality increased beyond the measured values.

Biogas production from day 100 to day 200 was relatively low, even when $\mathrm{pH}$ values were around 6.5 supposedly not inhibitory for methane production (Farquhar and Rovers, 1973; Ehrig, 1983), therefore other factors than $\mathrm{pH}$ may inhibit biogas production. These other factors inhibiting the biogas production could be high sulphate and ammonium concentrations in the leachate. Sulphate reduction, energetically a more efficient process than methanogenesis, is known to delay methane production during anaerobic digestion of solid waste. From day 200 onwards sulphate concentrations decreased from a constant concentration of $4 \mathrm{~g} \mathrm{~L}^{-1}$ to less than $1 \mathrm{~g} \mathrm{~L}^{-1}$ (Valencia et al, 2008b). This decrease in sulphate concentration coincided with the exponential increase of biogas production, supporting the hypothesis that sulphate reduction (substrate competition) and hydrogen sulphide (product inhibition) restricted the proper development of methanogenic bacteria. Concentrations of $\mathrm{H}_{2} \mathrm{~S}$ higher than $4 \mathrm{~g} \mathrm{~L}^{-1}$ were measured during this period, decreasing in a later stage to less than $0.2 \mathrm{~g} \mathrm{~L}^{-1}$. Unfortunately, LDAT is not able to model sulphate reduction. Consequently, relatively high concentrations of $\mathrm{NH}_{4}{ }^{+}$(Figure 3) were noticed during two different experiments (Valencia et al, 2008a, 2008b). Figure 3 shows that high concentrations of $\mathrm{NH}_{4}{ }^{+}$also corresponded with low biogas production periods. Biogas increased from day 200 onwards, not only because of a more neutral $\mathrm{pH}$, but apparently because also $\mathrm{NH}_{4}{ }^{+}$levels decreased below certain inhibition threshold level. This $\mathrm{NH}_{4}{ }^{+}$inhibition threshold was determined by methanogenic activity essays at different ammonium levels, which revealed that methane production is considerably reduced at levels higher than $2 \mathrm{~g} \mathrm{~L}^{-1}$, and even ceased at levels around $4 \mathrm{~g} \mathrm{~L}^{-1}$ (Valencia et al, 2008c). 


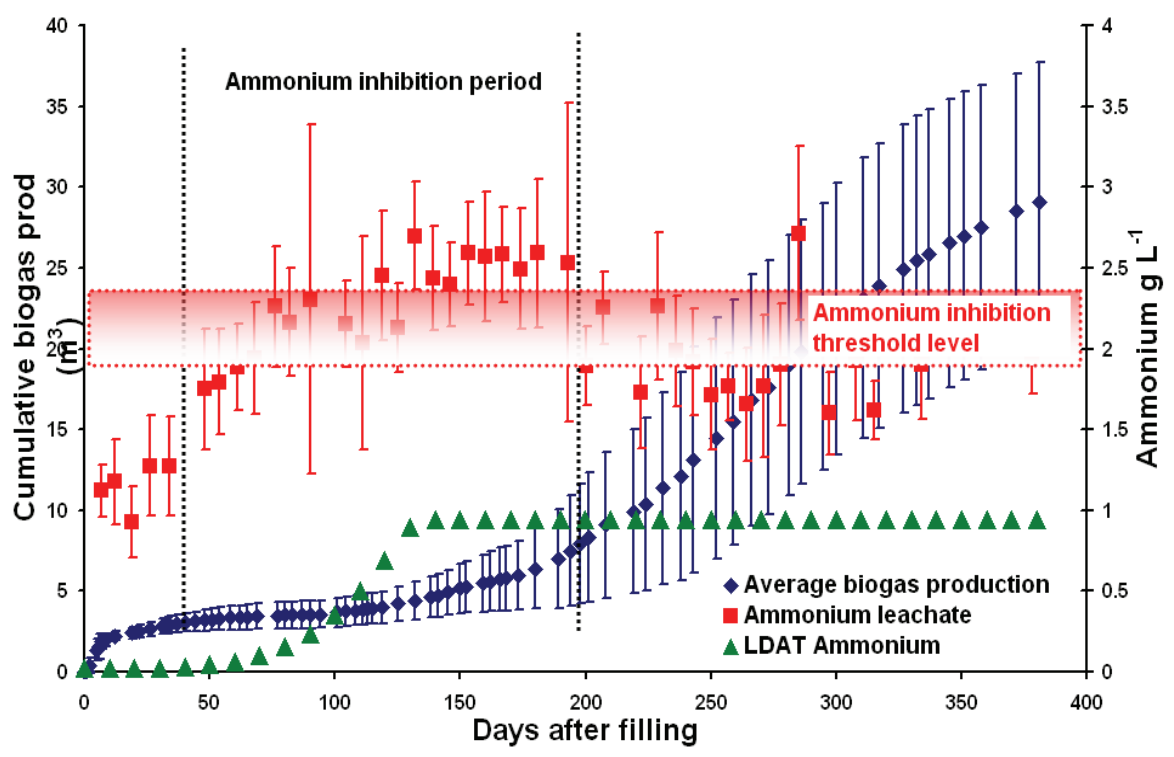

Figure 3. Cumulative biogas production and ammonium in the leachate of the simulators.

The LDAT model describes the $\mathrm{NH}_{4}{ }^{+}$production as function of the protein content of the waste (Figure 3). The $\mathrm{NH}_{4}{ }^{+}$produced according to LDAT was relatively low compared to the measured values. Increasing the protein content of the waste to $10 \%$, which was beyond the normal values of protein (4\% of dry weight) in waste (Jokela and Rintala, 2003; Jokela et al, 2005), not only increased the $\mathrm{NH}_{4}^{+}$content of the leachate $\left( \pm 2.1 \mathrm{~g} \mathrm{~L}^{-1}\right)$, but also increased the biogas production to $60 \mathrm{~m}^{3}$. Initially, $\mathrm{NH}_{4}^{+}$produced by previous processes (Valencia et al, 2008) dissolved into the leachate causing a relatively moderate increase in $\mathrm{NH}_{4}^{+}$levels. However, as enhanced hydrolysis of organic matter started, $\mathrm{NH}_{4}{ }^{+}$dissolved into the leachate reached inhibitory levels for methane production (day 50 until day 200) according to methanogenic essays mentioned above (Valencia et al, 2008c). Nevertheless, from day 200 onwards, different $\mathrm{NH}_{4}{ }^{+}$removal mechanisms (volatilisation, nitrification and denitrification, Anammox metabolism) started to predominate in the simulators and reduced $\mathrm{NH}_{4}{ }^{+}$levels below the inhibition level. Since these processes are not reflected by LDAT results, it is clear that the $\mathrm{NH}_{4}{ }^{+}$production and transformation equations in LDAT are different to what actually occurs in a bioreactor landfill with down-flow leachate recirculation. 


\section{Concluding remarks}

It is clear that MSW in landfills undergoes a series of diverse and complex processes of which not everything is known. Assumptions have to be made in order to simplify and achieve a best-case scenario of the processes occurring within a landfill. In the case of LDAT, the model describes relatively accurately the processes occurring in consolidating anaerobic reactors (CARs) (Ivanova et al, 2003; White et al, 2005). However, LDAT is not suitable to describe the processes (biogas production and $\mathrm{pH}$ evolution) in bioreactor landfill simulators operating under different conditions than the CARs. In order to improve LDAT performance for wider application the following problems should be addressed:

- LDAT biological and waste chemistry reactions must be expanded (i.g. intermediate compounds) to account for the changes of available substrate in time.

- Reaction rates (biological and chemical constants) should be adapted to the real process temperature (i.e. $\pm 30^{\circ} \mathrm{C}$ ).

- Substrate inhibition (i.e. VFA, sulphate) and product inhibition (i.e. ammonium, $\mathrm{H}_{2} \mathrm{~S}$ ) should be incorporated into the model.

- Incorporation of additional processes (i.e. nitrification and denitrification, volatilisation, Anammox metabolism and sulphate reduction) into the model should reduce the discrepancy of the simulation results.

Other models found in literature (Al-Yousfi and Pohland, 1998; Haarstrick et al, 2001; 2004; McDougall, 2007; Riechel et al, 2007) include a more accurate approach towards waste degradation by breaking down the biological process in several (about 8 to 12) enzymatic reactions. Al-Yousfi and Pohland (1998) and McDougall (2007) incorporated non-saturated flow equations governing leachate generation and transport through the waste mass. In these models, $\mathrm{pH}$ values were imposed forcing the microbiological kinetics to operate under the imposed conditions, which resulted in very accurate modelling results. However, despite the fact that these models include ionic balances, they do not consider all ionic dissolved species into the leachate that can influence the buffering capacity of the system. 
Achievement of neutral $\mathrm{pH}$ levels is crucial for the performance of the simulators, since they are the "driving force" that triggers all processes for MSW stabilisation (Valencia et al, 2008b). LDAT ionic balance did not include other dissolved species than bicarbonate. Therefore, models should address $\mathrm{pH}$ development and the changes of the leachate chemistry in time more accurately by incorporating ionic balances that include all dissolved species. This $\mathrm{pH}$ calculation is of outmost importance because it dictates the rates at which chemical and biological reactions take place in the simulators. The numbers of assumptions (i.e. uncertainties) are decreasing considerably because modelling tools and techniques are improving constantly and more detailed and longer data sets are becoming available. Nevertheless, based on this modelling exercise, more attention should be paid to inorganic chemistry, which determines the leachate characteristics and its influence on the buffer capacity of the landfill.

\section{References}

Ağdağ O.N., Sponza D.T. (2005). Effect of alkalinity on the performance of a simulated landfill bioreactor digesting organic solid wastes. Chemosphere, 59, 871-879

Al-Yousfi A.B., Pohland F.G. (1998). Strategies for simulations, design and management of solid waste disposal sites as landfill bioreactors. Pract. Period. Hazard. Toxic Radioact. Waste Manage. 2(1), 13-21.

Barlaz M.A., Ham R.K. (1993). Leachate and gas generation. In Daniel D.E. (Ed.) (1993). Geotechnical practice for waste disposal. Chapman \& Hall, London, UK.

Benson C.H., Barlaz M.A., Lane D.T., Rawe J.M. (2007). Practice review of five bioreactor/recirculation landfills. Waste Manage. 27, 13-29.

Ehrig H.J. (1983). Quality and quantity of sanitary landfill leachate. Waste Manage. Res. 1, 53-68.

El-Fadel M., Findikakis A.N., Leckie J.O. (1996). Numerical modelling of generation and transport of gas and heat in landfills. Waste Manage. Res. 14, 483-504.

El-Fadel M., Khoury R. (2000). Modelling settlement in MSW landfills: A critical review. Crit. Rev. Env. Sci. Technol. 30 (3), 327-361.

Farquhar G.H., Rovers F.A. (1973). Gas production during refuse decomposition. Water Air Soil Pollut. 2(4), 483-495. 
Gurijala K.R., Suflita J.M. (1993). Environmental factors influencing methanogenesis from refuse in landfill samples. Environ. Sci. Technol. 27, $1178-1181$.

Haarstrick A., Hempel D.C., Ostermann L., Ahrens H., Dinkler D. (2001) Modelling of the biodegradation of organic matter in municipal landfills. Waste Manage. 19, 320-329

Haarstrick A., Mora-Naranjo N., Meima J., Hempel D.C. (2004). Modeling anaerobic degradation in municipal landfills. Environ. Eng. Sci. 21, 471484.

Hudson A.P., White J.K., Beaven R.P., Powrie W. (2004). Modelling the compression behaviour of landfilled domestic waste. Waste Manage. 24, 259-269.

Ivanova L.K., Richards D.J., Smallman D.J. (2003). An investigation into the factors affecting secondary settlement of wastes. In T.H. Christensen, R. Cossu, R. Stegmann (Eds.): Sardinia 2003 "Ninth International Waste Management and Landfill Symposium" October 6-10, 2003, S. Margherita di Pula, Cagliari, Italy.

Jokela J.P.Y., Rintala J.A. (2003). Anaerobic solubilisation of nitrogen from municipal solid waste. Rev. Environ. Sci. Biotechnol. 2, 67-77.

Jokela J.P.Y., Vavilin V.A., Rintala J.A. (2005). Hydrolysis rates, methane production and nitrogen solubilisation of grey waste components during anaerobic degradation. Bioresour. Technol. 96, 501-508.

McDougall J. (2007). A hydro-bio-mechanical model for settlement and other behaviour in landfill waste. Comput. Geotech. 34, 229-246.

McGreanor P.T., Reinhart D.R. (2000). Mathematical modelling of leachate routing in a leachate recirculating landfill. Wat. Res. 34 (4), 1285-1295.

Morris J.W.F., Vasuki N.C., Baker J.A., Pendleton C.H. (2003). Findings from long-term monitoring studies at MSW landfills facilities with leachate recirculation. Waste Manage. 23, 653-666.

Ozkaya B., Demir A., Bilgili M.S. (2006). Mathematical simulation and long-term monitoring of leachate components from two different landfill cells. J. Hazard. Matter. A135, 32-39.

Pohland F.G. (1980). Leachate recycle as landfill management option. $J$. Environ. Eng.-ASCE. 106, 1057-1069.

Pohland F.G. (1996). Landfill Bioreactors: fundamentals and practice. Water Qual. Int. 9/10, 18-22. 
Reichel T., Ivanova L.K., Beaven R.P., Haarstrick A. (2007). Modeling decomposition of MSW in a consolidating anaerobic reactor. Environ. Eng. Sci. 24, 1072-1083.

Reinhart D.R., Al-Yousfi A.B. (1996). The impact of leachate recirculation on municipal solid waste landfill operating characteristics. Waste Manage. Res. 14, 337-346.

Reinhart D.R., Townsend T.G. (1998). Landfill bioreactor design \& operation. Lewis Publishers, New York, USA.

Valencia R., van der Zon W., Woelders H., Lubberding H.J., Gijzen H.J. (2008a). Achieving "Final Storage Quality" of municipal solid waste in pilot scale bioreactor landfills. Waste Manage. (2008) in press. DOI:10.1016/j.wasman.2008.02.008

Valencia R., van der Zon W., Woelders H., Lubberding H.J., Gijzen H.J. (2008b). The effect of hydraulic conditions on waste stabilisation in bioreactor landfill simulators. Submitted to Bioresour. Technol

Valencia R., van der Zon W., Woelders H., Lubberding H.J., Gijzen H.J (2008c). Ammonium release and Anammox as an option for its removal in bioreactor landfill simulators. Submitted to Environ. Sci. Technol.

van Dam A.A. (2005). Environmental Modelling. Lecture notes LND236/05/1, UNESCO-IHE Institute for Water Education. Delft, The Netherlands.

Vavilin V.A., Rytov S.V., Lokshina L.Y., Pavlostathis S.G., Barlaz M.A. (2003). Distributed model of solid waste anaerobic digestion: Effects of leachate recirculation and $\mathrm{pH}$ adjustment. Biotechnol. Bioeng. 81(1). 6673.

White J., Haarstrick A., Kindlein J., Reichel T., Ivanova L.K., Beaven R.P. (2005). Experimental investigations of organic degradation and comparison of two numeral simulations. In T.H. Christensen, R. Cossu, R. Stegmann (Eds.): Sardinia 2005 "Tenth International Waste Management and Landfill Symposium” October 3-7, 2005, S. Margherita di Pula, Cagliari, Italy.

White J., Robinson J., Ren Q. (2004). Modelling the biochemical degradation of solid waste in landfills. Waste Manage. 24, 227-240.

White J.K., Ren Q., Robinson J.P. (2003). A framework to contain a spatially distributed model of the degradation of solid waste in landfills. Waste Manage. Res. 21, 330-345. 
Young A. (1989). Mathematical modelling of the methanogenic ecosystem. J. Chem. Tech. Biotechnol. 46(3), 189-208.

Zacharof A.I., Butler A.P. (2004). Stochastic modelling of landfill leachate and biogas production incorporating waste heterogeneity. Model formulation and uncertainty analysis. Waste Manage. 24, 453-462. 



\section{7 \\ Chapter}

\section{Conclusions and outlook}

Success is the ability to go from one failure to another with no loss of enthusiasm.

Sir Winston Churchill (1874-1965)

\section{The past: what we did not know}

The concept of sanitary landfill has existed for over a century and it is still considered, even in international legislation, as the least desired option in the wide spectrum of waste management options. The landfilling of waste is the least preferred treatment option due to the space requirements involved, the need of aftercare in perpetuity, the loss of material resources, and the pollution caused by the leachate and biogas escaping from landfill sites. Despite this negative public and political perception, landfills shall continue to be the most flexible, reliable and economical method of waste containment and disposal around the world. Substantial landfill research was done between mid 1980s and mid 1990s. However, changes in the international political arena during mid 1990s and early 2000s, specially in the European Union, restricted further developments on landfill research, with the exception of improvements on liners aimed at sealing landfills to prevent or reduce air, soil and water pollution (bottom and top covers). In order to protect human health and the environment from the negative impacts of landfilling of waste, the European legislation aimed at reducing the amount of waste deposited in landfills using mechanisms such as landfill taxation, banning landfilling of specific (waste) materials and encouragement of waste incineration. Additionally, more stringent standards have been imposed in order to isolate the waste from the biosphere preventing the entry of moisture. Nevertheless, current (sanitary) landfills 
are considered a liability for landfill operators and municipalities, since isolation barriers will eventually fail allowing the intrusion of moisture that will trigger restrained biological and chemical processes. These restrained processes will cause leachate and landfill gas emissions into the atmosphere, usually long after the legal monitoring periods have ceased. Little more than 30 years, landfill research pioneers started to conduct experiments on which later became to be known as the bioreactor landfill concept. Their research highlighted the importance of operational parameters such as moisture and liquid channelling and distribution on the enhancement of waste degradation in landfills. During the last two decades several approaches to improve waste degradation in landfills were proposed, the so-called enhancement techniques. However, most of these approaches have been tested at laboratory or pilot-scale with positive results but without generating economically viable solutions at full-scale. The proposed approaches were neither technically nor financially feasible at full-scale. The main practical problem seems to be the homogenous addition and distribution of the added liquid due to the heterogeneity of the waste matrix.

In a five years retrospective, it was not known how different combinations of these enhancement techniques could enhance further the waste degradation process or how the mechanical and hydraulic properties of waste changed or could change in time due to the implementation of these enhancement techniques. Little information existed about the inherent microbial dynamics or the geochemical processes occurring within the (bioreactor) landfill mass. In these last five years, the political perception has started to change slowly, thus granting, beside limited funds, "escape" windows that allow landfill operators to conduct R\&D efforts to demonstrate the value and importance of bioreactor landfills within the wide range of waste management options.

\section{The present: what we know now}

Municipal solid waste degraded in (bioreactor) landfills undergoes a series of diverse and complex processes. Every year researchers around the world increase the knowledge not only on these diverse and complex processes, but also about other issues within the municipal solid waste management system (i.e. prevention, collection, reuse, recycling, alternative treatments, etc.). 
American and Australian universities and landfill operators focus more on maximisation of biogas production and capture for energy purposes. Most of these research efforts are conducted at full-scale, which is the uniqueness of their research. However, the diverse approaches and the variability of results have made it impossible to declare bioreactor landfills as the most efficient and effective method of waste disposal. Moreover, their research focuses more on the biological stabilisation rather than on the final characteristics of the residues. In contrast, European universities and research centres are looking mainly into issues related to Final Storage Quality (FSQ) ${ }^{1}$ status by understanding the influence of waste mechanics and hydrodynamics on the MSW degradation process in landfills. However, they focus more on mathematical modelling of the processes, because due to the legal restrictions in place most of their experimental efforts are being carried out at laboratory and pilot-scales.

This thesis attempted to combine previous knowledge and apply influencing measures focusing to achieve FSQ of waste residues in landfills, resulting in the development of new insights about physical, chemical and biological dynamics occurring with bioreactor landfill simulators.

\subsection{Physical dynamics}

Physical dynamics refers to the interaction between moisture, waste particles and microorganisms. Three main findings can be highlighted:

- Raising waste moisture content ( $>$ field capacity) increases the rate of waste stabilisation. However, it did not prevent inhibition problems due to by-products (i.e. ammonium) or failure of the system (i.e. clogging) (Chapter 2).

- Modifying the hydraulic conditions (i.e. homogenous gravel-MSW mixtures) improve moisture distribution and movement within the simulators reducing the biological stabilisation periods (Chapter 4).

\footnotetext{
${ }^{1}$ FSQ suggests that the potential of a waste material to produce pollution is reduced to nearly zero in the long-term perspective
} 


\subsection{Chemical dynamics}

Chemical dynamics are related to changes of waste composition due to physical dynamics and microbial activities. In that context, the following findings are important to emphasise:

- The buffering capacity of the system has the same importance as moisture content and movement, since neutral $\mathrm{pH}$ values are the "driving force" that triggers all the processes for waste stabilisation (Chapter 4)

- The achievement of FSQ status depends strongly on the initial MSW composition and to the different modi operandi (i.e. anaerobic \& aerobic) applied to the system (landfill) (Chapter $2 \& 4$ ).

- The residues of the experiments were not only close to complying with the stringent criterion set in the WAC for inert waste of the Landfill Directive but fulfilled all other biological stabilisation standards set by researchers elsewhere. This has been the first documented attempt to reach and define FSQ status of waste residues by a certain numeric data set (WAC for inert waste) (Chapter $2 \& 4$ ).

- The bioreactor landfill approach can efficiently transfer approximately $45 \%$ of the total carbon and nitrogen from the solid phase into the liquid and gaseous phases, leaving a residue that is biologically stable (Chapter 2 \& 4).

\subsection{Biological dynamics}

Biological dynamics are related to the successful development of microbiological communities due to the influenced environmental conditions. The core of this thesis is based on these biological dynamics and the most important findings are:

- Co-disposal of septic tank sludge with MSW enhances the waste stabilisation process by increasing moisture availability and provision of a more acclimatised and active microbial population. In addition, codisposal is an environmentally sound, relatively low cost and safe disposal option that, if proper infrastructure is in place, can be implemented in developing countries to increase gas production for energy purposes (Chapter 3).

- The risks and hazards associated with septic tank sludge (total and faecal coliforms contamination) are practically eliminated and may provide 
significant improvement to current septage management practices in place min many developing countries. Harsh environmental conditions were the most influential factors governing the die-off process of pathogenic bacteria in the bioreactor landfill simulators (Chapter 3).

- Ammonium release in bioreactor landfill simulators is governed initially by physical processes, followed by microbiological conversion of protein (MSW) (Chapter 5).

- Intrusion of small quantities of $\mathrm{O}_{2}$ is beneficial for the ammonium removal from MSW, because it triggers in-situ nitrification, which in turn could have promoted the growth of Anammox bacteria (Chapter 5).

- Anammox bacteria were present in bioreactor landfills and are likely to have contributed substantially to the N-removal from the solid matrix (Chapter 5).

\subsection{Mathematical modelling}

- Despite slight discrepancy in results, mathematical models are able to represent the main processes (microbial kinetics and liquid and gas transport) occurring within the bioreactor landfills. Coupling of chemical mediated processes (dissolution and buffering) with already well known microbial and transport processes can increase the accuracy of the models to describe the aforementioned processes (Chapter 6).

In conclusion, this research reduced our current gaps-in-knowledge and offered feasible technical alternatives to control and stir the processes occurring in a bioreactor landfill aiming to achieve FSQ status of residues.

\section{The future: what we still need to know further}

The future of bioreactor landfills in Europe, at least in the legislation, is dubious not only because less organic material will be deposited in landfills but because of the legal barriers (banning of liquid addition and restriction on co-disposal with bio-wastes) in place for it operation. However, bioreactor landfills might become an important part of the waste management system due to their flexibility. Nevertheless, we need to continue increasing our knowledge of the diverse and complex processes occurring within bioreactor landfills in order to use to implement bioreactor 
landfills as sustainable methods of waste disposal which are able to achieve FSQ status of residues. The following questions still remain to be answered in the research agenda:

Is it possible to achieve FSQ status of residues in bioreactor landfills within a generation timeframe?

The work presented in this thesis demonstrated that biological stabilisation of MSW can be achieved within a generation timeframe using the bioreactor landfill approach. In order to achieve FSQ of waste, it is of outmost importance to know more about the geochemical processes (precipitation, complexation ${ }^{2}$, adsorption, absorption, etc.) occurring within the bioreactor landfill and their influence on the achievement of residues FSQ status within a generation timeframe.

\section{What it is the nature of nitrogen remaining in the residues?}

Nitrogen compounds are considered as the main pollutants that will jeopardise the achievement of FSQ status of residues. Even after biogas production has ceased, it is still unknown whether the residual nitrogen would be susceptible for physical, chemical and/or biological activity.

\section{Do Anammox bacteria contribute to remove nitrogen in full-scale (bioreactor) landfills?}

Since, this work is the first to report on Anammox bacteria existence in bioreactor landfill simulators, it would be interesting to know if these occur also in real-scale bioreactor landfills or even in conventional landfills. In case it occurs, it will be important to define and implement the proper conditions for Anammox development. Moreover, it will be essential to establish the real Anammox contribution to the total nitrogen removal process in a bioreactor landfill.

\section{Does the current modelling knowledge can be applied to improve bioreactor landfill designs?}

In order to increase modelling accuracy of the processes within bioreactor landfills it is necessary to incorporate waste physical and

\footnotetext{
${ }^{2}$ The process by which one substance is converted to another substance in which the constituents are more intimately associated than in a simple mixture, generally rendering them less available for uptake by living organisms
} 
chemical characteristics changes due to implementation of new technical approaches (recirculation schemes, changes on hydraulic conditions, interaction between gases, liquids and solids, etc.). Additionally, since all processes are enhanced also inhibitors, inhibition mediated processes (ammonium, hydrogen sulphide, heavy metals, etc.) need to be included into these models. Full-scale bioreactor landfills have been working now approximately for 7-10 years, although they differ on operational conditions, field-data from these landfills can be used for validation of these proposed models.

\section{Can laboratory enhancement techniques be applied to improve full- scale bioreactor landfill performance?}

Homogenous liquid addition and distribution is reported as the main technical problem at field-scale. Implementation of new technical approaches (different leachate recirculation schemes, addition of bio-solids, MSW shredding, incorporation of waste coarse materials) to improve moisture distribution should be carried out now at field-scale. However, their application requires a previous careful and detailed analysis due to financial and technical implications associated with these activities at full scale. Some of these activities are labour intensive and costly. Moreover, the massive volumes of MSW that have to be processed will represent a monumental task for landfill operators. Nevertheless, the associated benefits of achieving FSQ status (i.e. stop aftercare monitoring programs) could off-set the financial and technical implications of these activities.

The implementation of the bioreactor landfill approach in Europe will depend strongly on the possibility to achieve FSQ status of residues. Research and Demonstration are necessary to validate the vast amount of laboratory experiences and data allowing landfill operators higher flexibility to implement different and diverse strategies to achieve FSQ status. 

1

\section{Annex}

The most exciting phrase to hear in science, the one that heralds new discoveries, is not 'Eureka!'

but 'That's funny...'

Isaac Asimov (1920-1992) 
Schematic view of the pilot scale bioreactor landfill simulators

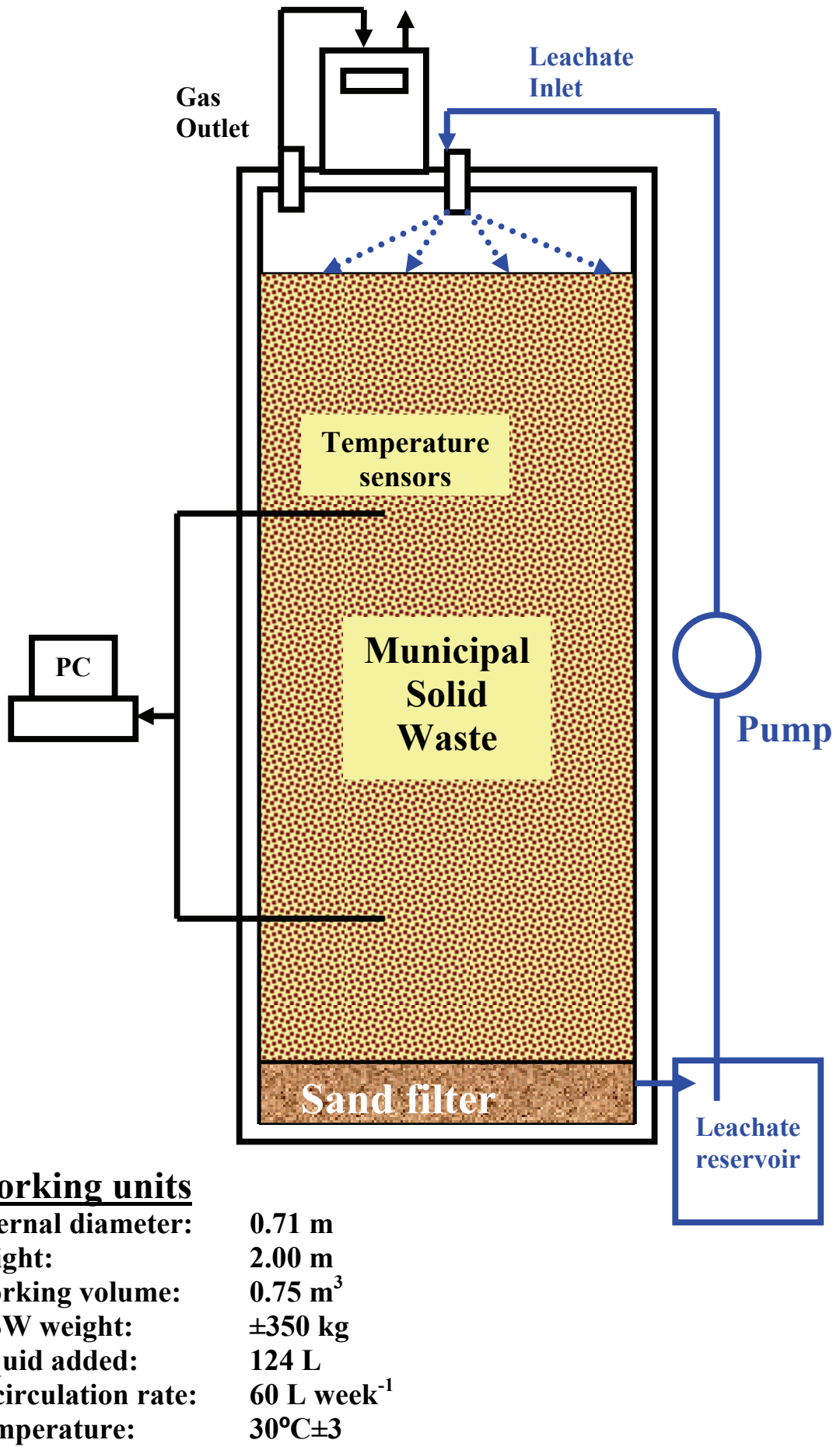


Schematic view of the different pilot-scale simulators
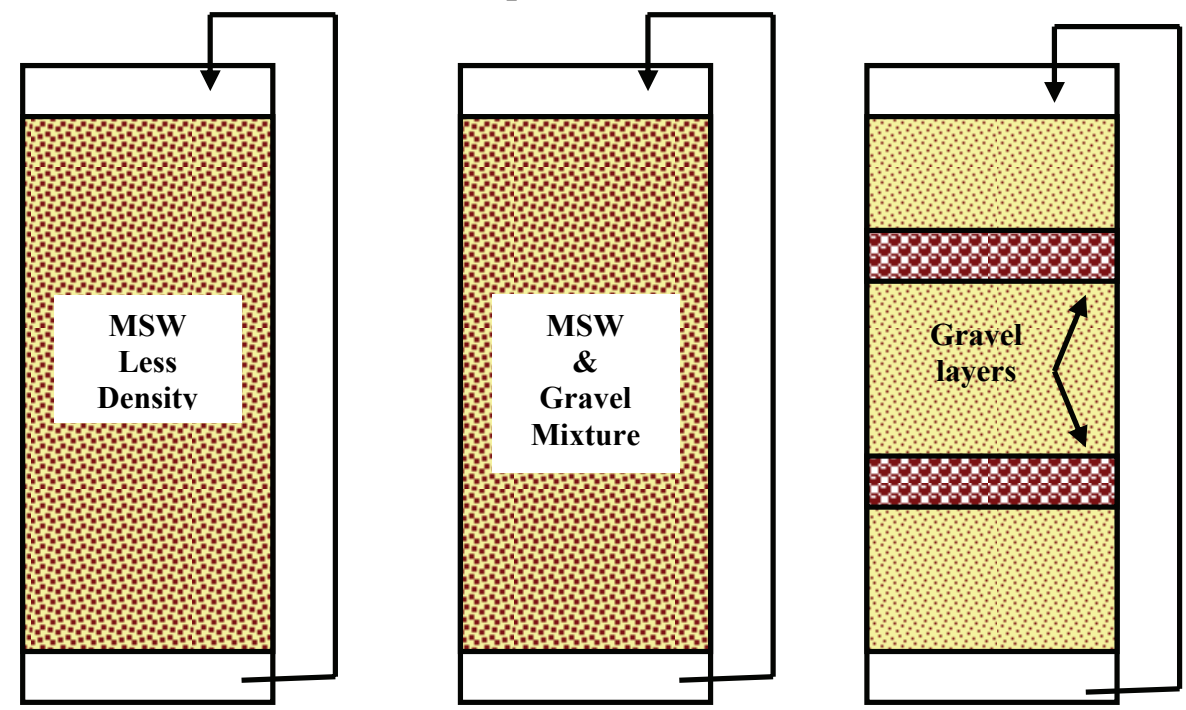

View of the laboratory bioreactor landfill simulators
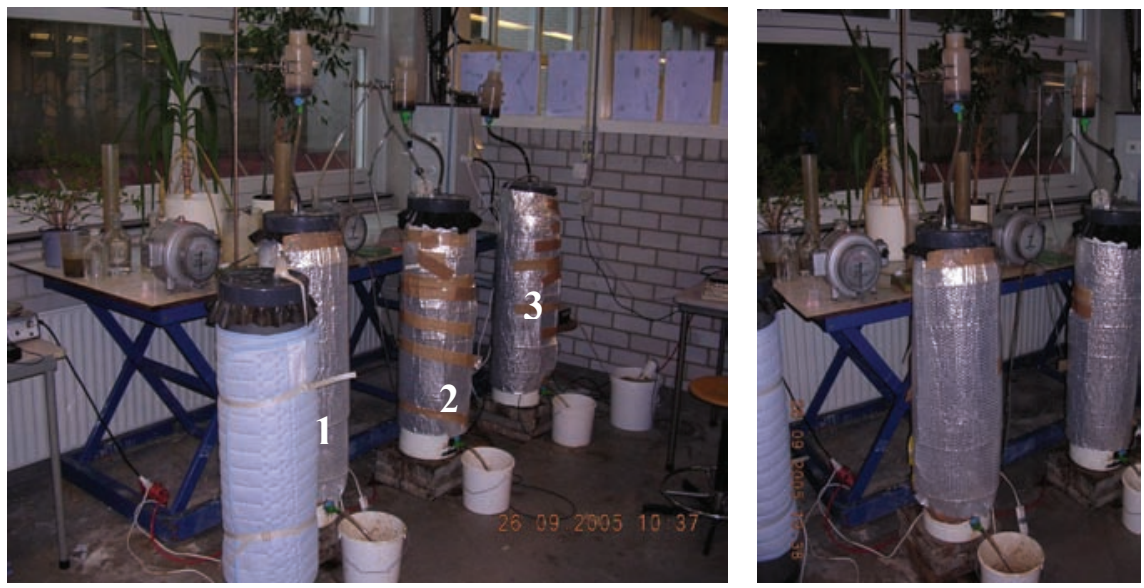

\section{Working units}

Internal diameter:

Height:

Working volume:

Weight:

Liquid added:

Temperature
Simulators arrangements

\begin{tabular}{|l|l|}
\hline 1 & $100 \%$ MSW \\
\hline 2 & $90 \%$ MSW $+10 \%$ Septage \\
\hline 3 & $75 \%$ MSW $+25 \%$ Septage \\
\hline
\end{tabular}

$32 \mathrm{~kg}$

$5 \mathrm{~L}$

$30^{\circ} \mathrm{C} \pm 0.5$ 


\section{Photos of the bench scale simulators}

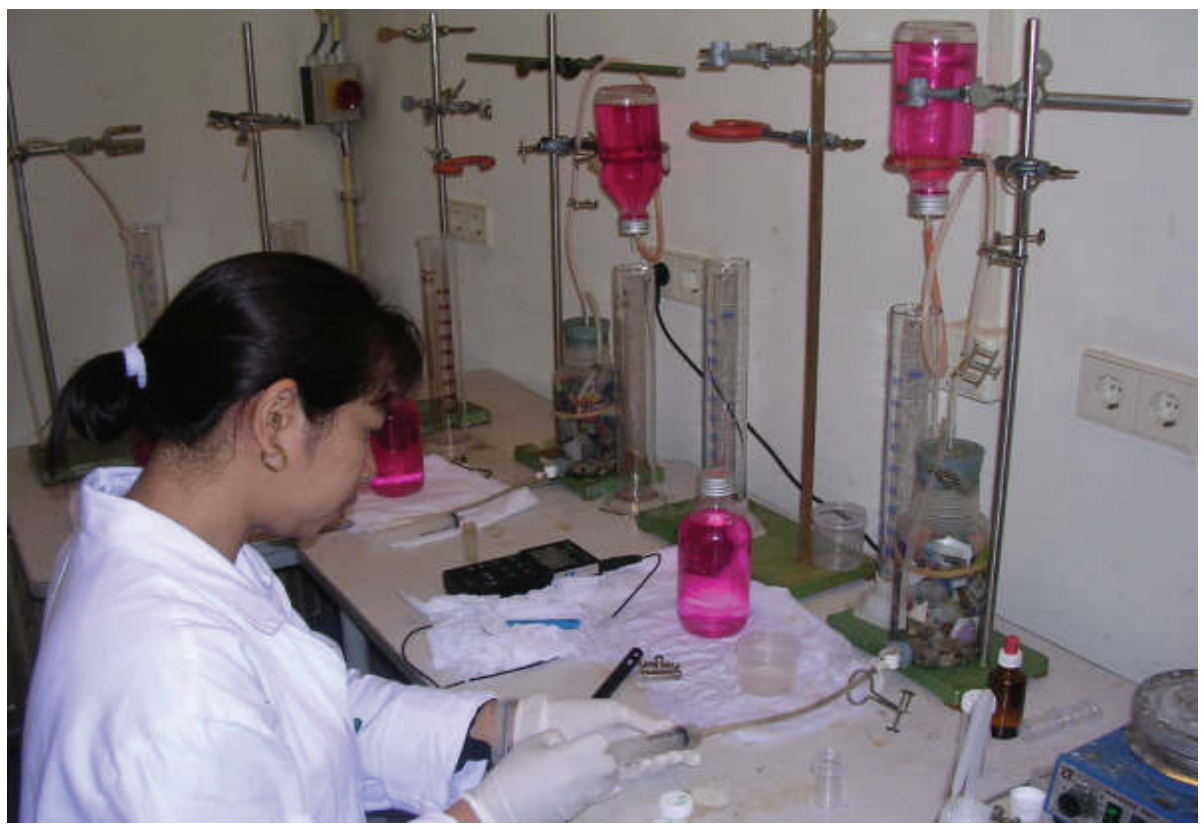

Small scale simulators ( $1 \mathrm{~L}$ volume) used for methanogenic activity test and specific variable experiments (ammonium release, temperature and $\mathrm{pH}$ dependence, pathogen survival). The displacement method was used for measuring gas production. Simulators had similar operational features as the laboratory and pilot scale simulators.
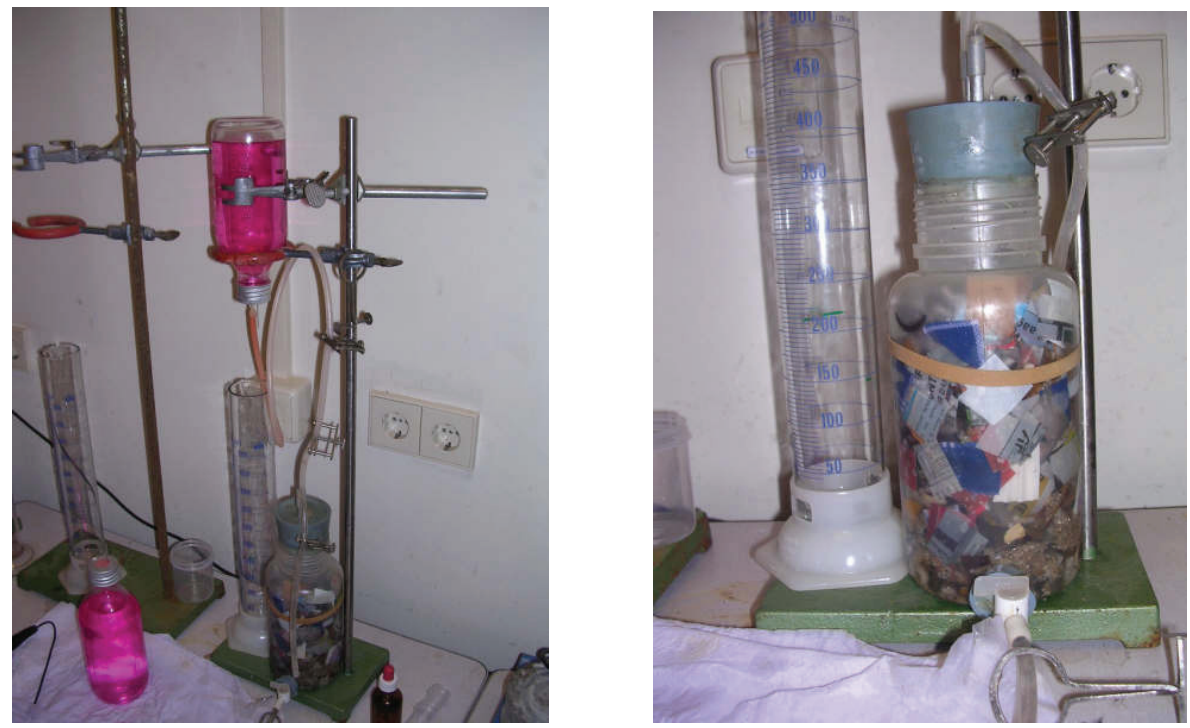


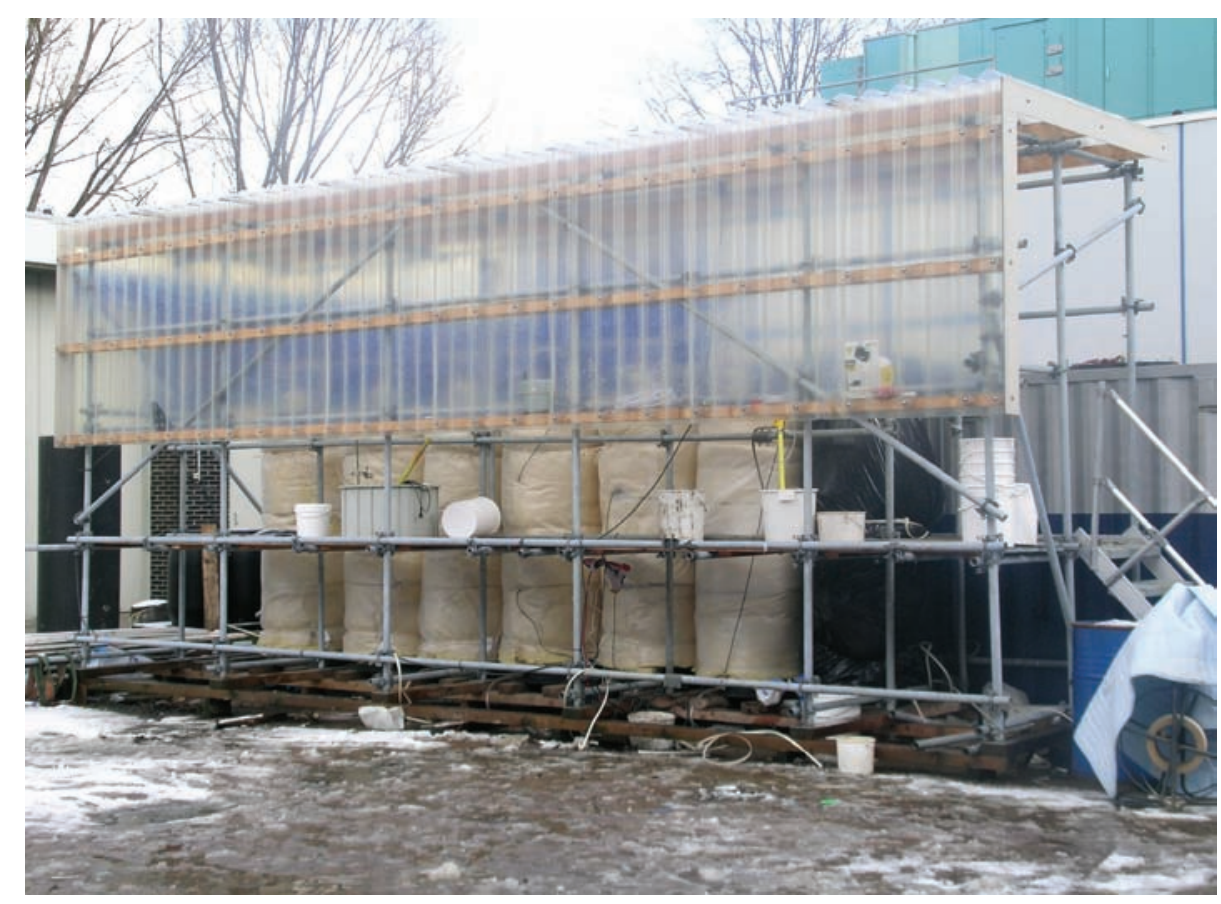

Frontal view of the pilot-scale simulators

Simulators were heated by electrical blankets and isolated by aluminum foil and roof-isolation material and finally wrapped with plastic.

Temperature sensors were placed at 50 and $150 \mathrm{~cm}$ from the bottom. Leachate was collected at the bottom and recirculated at the top of the simulators.

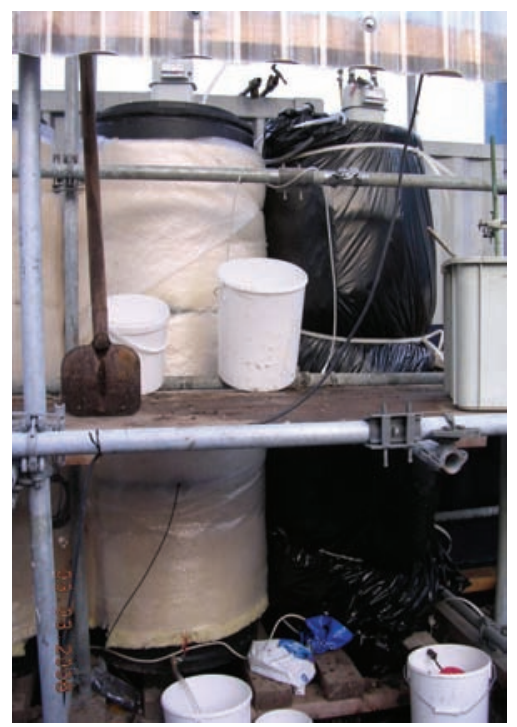




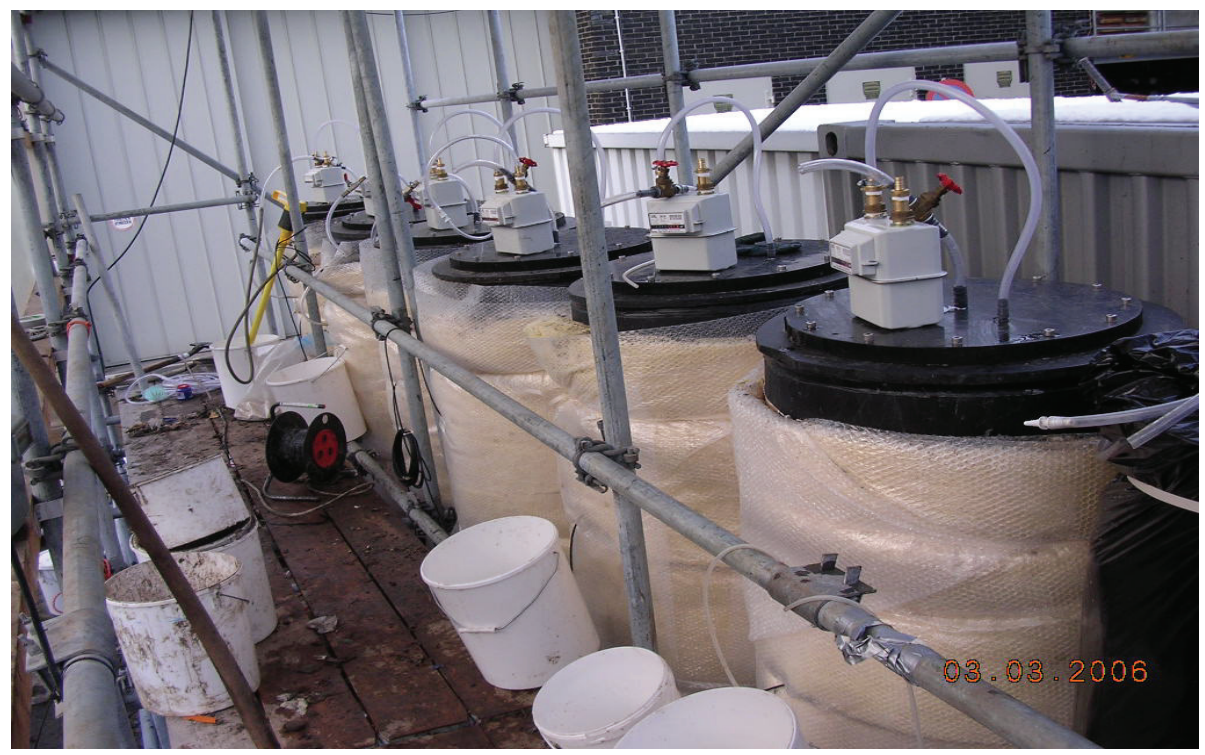

\section{Top view of the simulators}

Gas meters were installed at the top to record total biogas production. Originally, precision wet meters were used and changed to dry commercial meters, due to severe winter conditions.

Biogas composition was measured with portable gas analyser.
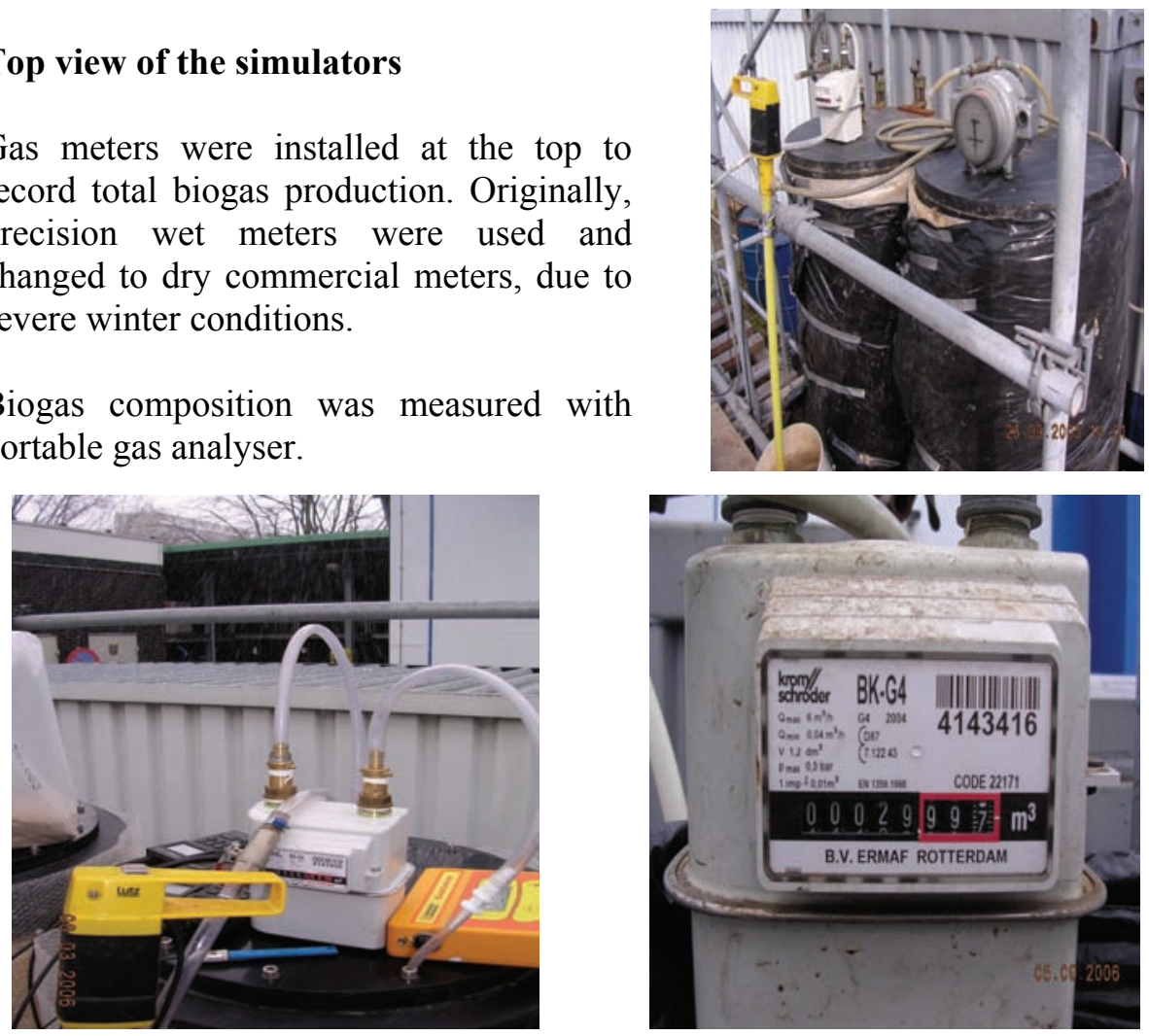


\section{Municipal Solid Waste}

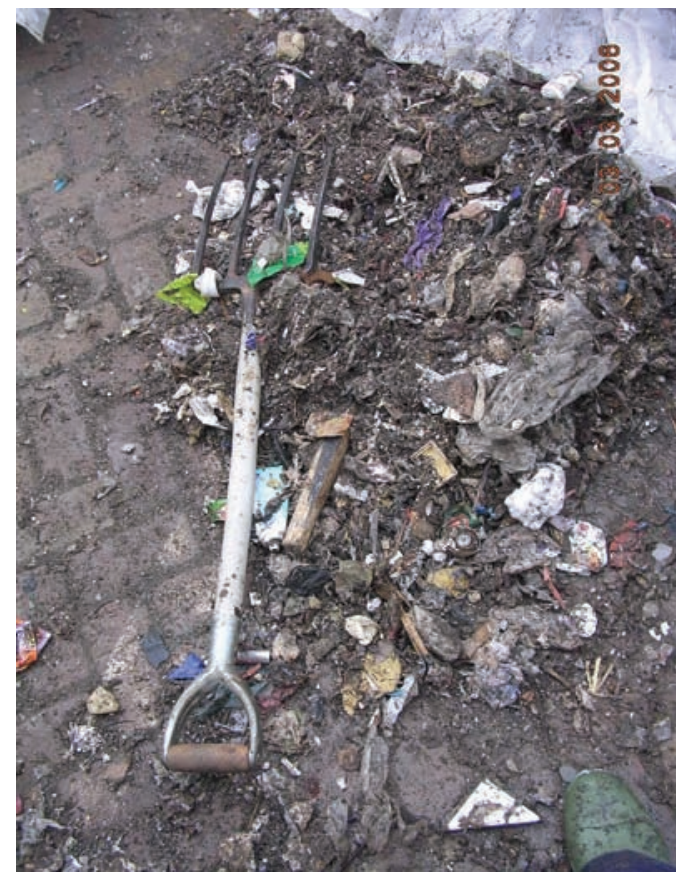

Municipal solid waste $( \pm 20 \%$ moisture content) was shredded (4 cm max.).

Upon arrival the MSW temperature was $\pm 50^{\circ} \mathrm{C}$, because during transport MSW started to undergo a composting process.
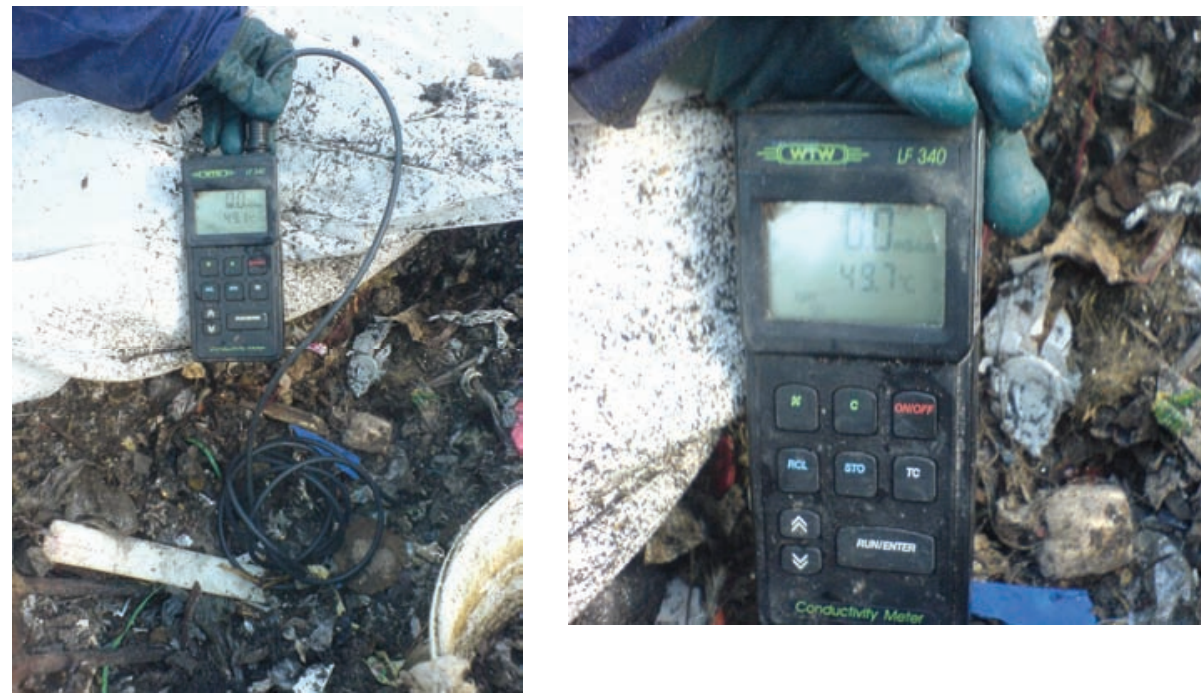


\section{Final sampling of MSW from the simulators (after 1 year)}

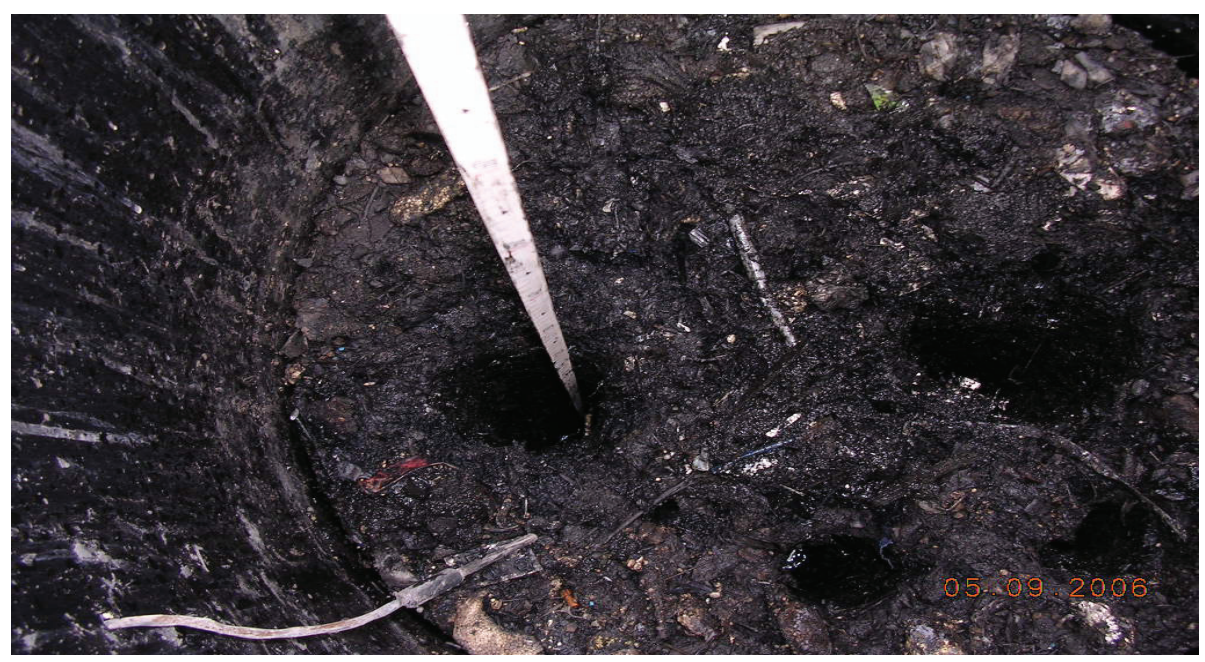

Core samples were taken from each simulator at the end of the experiment. Samples were analysed for moisture, organic content and elemental composition.

After 1 year, the headspace increased to about $50 \mathrm{~cm}$.

Residues had a sludge-like appearance, tar-like "pleasant" odour and lack of structural properties
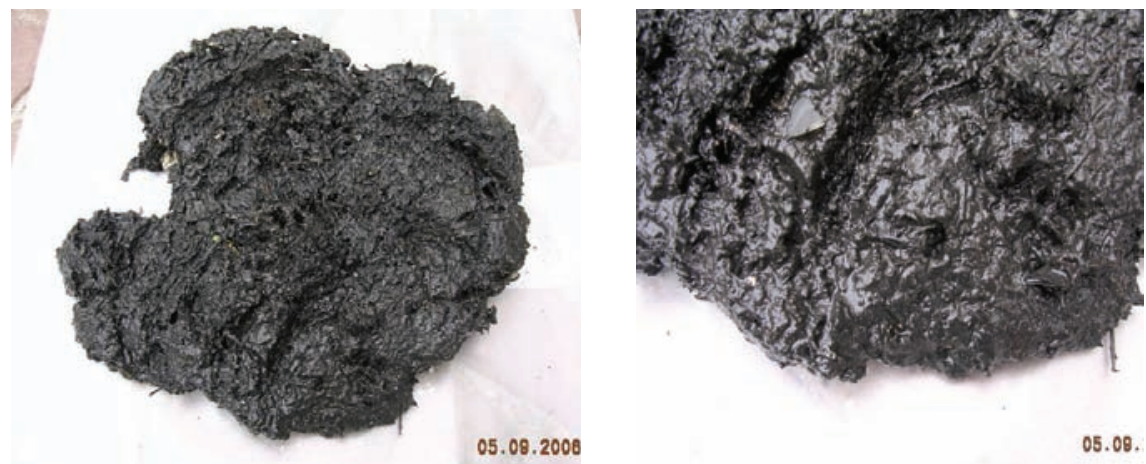


\section{Samenvatting}

Toegenomen ontwikkeling en de verstedelijking hebben geleid tot een alsmaar groter wordende hoeveelheid huishoudelijk afval per hoofd van de bevolking. Dit afval bestaat uit organische en anorganische fracties, waarvan de afbreekbaarheid varieert van gemakkelijk via moeilijk tot onafbreekbaar. Voor al deze vormen van afval bestaan verwerkingsmethoden: hergebruik, composteren, anaerobe vergisting, verbranding en storten zijn de meest gangbare manieren; pyrolyse en vergassing worden nog nauwelijks toegepast. Welke verwerkingsmethode er ook wordt gekozen, er zal altijd een restfractie overblijven die gewoonlijk eindigt op stortplaatsen, meestal in zogenaamde sanitary landfills. De belangrijkste functie van sanitary landfills is om het afval en de producten die ontstaan door afbraak van het afval te isoleren van hun omgeving met als doel mens en milieu te beschermen. Uiteindelijk zullen echter de beschermende lagen het begeven, zodat het naar binnen sijpelende water fysische, chemische en biologische processen in gang zet die het resterende afval alsnog omzetten, resulterend in verontreinigd percolaat en stortgassen.

Het beperken van de negatieve gevolgen van het storten van afval heeft geresulteerd in de bioreactor landfill. In de bioreactor landfill wordt actief ingegrepen om de micro-organismen optimaal te laten functioneren en de afbreekbare materialen zo snel mogelijk om te zetten in een stabiel restproduct; vaak wordt water toegevoegd en/of gas doorgeblazen. Verder onderzoek heeft geleid tot het vaststellen van de boven- en ondergrenzen voor de belangrijkste proces parameters en tot het instellen van alternatieve operationele omstandigheden: de zogenaamde procesversnellende technieken. De bioreactor landfill kan op twee manieren benaderd worden: 1) vanuit Amerikaans perspectief, waarin geprobeerd wordt om met behulp van deze procesversnellende technieken zoveel mogelijk stortgas te produceren; of 2) vanuit Europees perspectief, waarin geprobeerd wordt om een stabiel eindproduct (FSQ, Final Storage Quality) te realiseren binnen 30 jaar. De term FSQ suggereert dat er geen verontreiniging meer mogelijk is uit het afvalmateriaal en dat het restproduct vergelijkbaar is met de karakteristieken voor gestabiliseerd afval, zoals beschreven in de Waste Acceptance Criteria (WAC) van de Europese Landfill Directive. Het 
grootste technische probleem waarmee stortplaatsbeheerders te maken krijgen is om het water homogeen te verdelen over het vaste materiaal.

De primaire doelstelling van dit onderzoek was om FSQ kwaliteit te bewerkstelligen via laboratorium en pilot-plant experimenten. Deze FSQ status moet voldoen aan de WAC van de Europese Landfill Directive voor inert afval, wat algemeen beschouwd wordt als worst-case scenario vanwege de stricte regelgeving. Dit proefschrift richtte zich op de interactie tussen en de eventuele modificatie van de factoren die het stabilisatieproces van het afval bepalen en om de fysische, chemische en biologische processen die zich afspelen in een bioreactor landfill beter te kunnen begrijpen.

Op laboratoriumschaal (1 en 50 liter) en pilot-plant schaal (800 liter) werd met verschillende combinaties van procesversnellende technieken (versnipperen van afval, toedienen van buffer en/of septic tank slib, doorblazen van lucht) gewerkt om FSQ kwaliteit te bereiken. Verder werd er aanvullend grof materiaal toegevoegd (in lagen of gemengd) om de hydraulische eigenschappen te verbeteren. De resultaten lieten zien dat het weliswaar mogelijk was om het materiaal binnen een jaar biologisch te stabiliseren, maar het leidde nog niet tot FSQ kwaliteit. Het bereiken van deze FSQ status lijkt vooral samen te hangen met de samenstelling van het aangeboden afval. Desalniettemin waren de residuen sterk vergelijkbaar met de WAC van de Landfill Directive voor inert afval. Het toevoegen van een buffer of septic tank slib had een positief effect op het stabiliseren van de residue fractie van het afval, vooral omdat de biogasproductie eerder op gang kwam. Ook werden er na een jaar geen faecale coliformen meer aangetroffen, waardoor het toedienen van septic tank slib geen verdere risico's meebrengt. Ook het toepassen van aanvullend grof materiaal aan het afval had een versneld effect op het stabilisatieproces: het mengen van het afval met deze materialen gaf een beter resultaat dan het aanbrengen van deze materialen in lagen, omdat daarbij nogal verstoppingen optraden.

De belangrijkste factor die het bereiken van FSQ kwaliteit in de weg staat, en dus het veilig sluiten van een stortplaats verhindert, is de aanwezigheid van stikstof (met name $\mathrm{NH}_{4}^{+}$) en daarom hebben de productie en de verwijdering van stikstofverbindingen veel aandacht gekregen in dit proefschrift. Via fysische processen kwam $40 \%$ van alle $\mathrm{NH}_{4}{ }^{+}$binnen 24 uur 
vrij uit het afval; de andere $60 \%$ kwam vrij door biologische omzetting van de in het afval aanwezige eiwitten. Voor het eerst werden Anammox bacteriën aangetoond in vast afval dat verwerkt wordt in bioreactor landfills en deze bacteriën zouden wel eens een belangrijke rol kunnen spelen in de afname van $\mathrm{NH}_{4}{ }^{+}$in de tijd. Niet duidelijk is echter geworden waar de intermediaire verbindingen, nodig voor het functioneren van het Anammox systeem (met name nitriet), vandaan kwamen.

Om de productie van koolstof- en stikstofverbindingen te simuleren is het Landfill Degradation and Transport (LDAT) model gebruikt. Dit LDAT model was echter niet geschikt om de processen die plaats vonden in de reactoren adequaat te beschrijven, vooral omdat het model de processen op een vaste temperatuur $\left(20^{\circ} \mathrm{C}\right)$ liet plaats vinden en de chemische formules in dit model verbetering behoeven. Andere modellen zouden wel eens beter geschikt kunnen zijn om deze processen te beschrijven, maar missen een correcte ionenbalans, die van grote invloed is op de $\mathrm{pH}$ van het systeem.

Geconcludeerd kan worden dat de $\mathrm{pH}$ een belangrijke rol speelt: de de stijging van de $\mathrm{pH}$ tot neutrale waarden "triggerde" de meeste processen in de reactoren. Dit proefschrift legde de nadruk op de noodzaak om het systeem in de toekomst te modelleren met behulp van een correcte ionenbalans en het effect daarvan op het bereiken van een neutrale (en misschien basische) $\mathrm{pH}$.

Dit onderzoek heeft bijgedragen tot een vermindering van de hiaten in onze kennis van de verwerking van vast afval en laat haalbare technische oplossingen zien om de processen in bioreactor landfills te beheersen en te sturen om uiteindelijk tot FSQ kwaliteit te komen. 



\section{Curriculum Vitae}

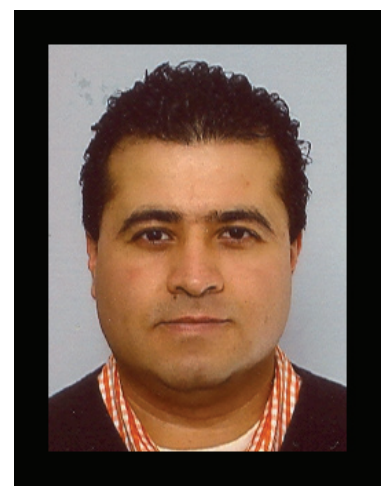

Roberto Valencia Vázquez was born on $19^{\text {th }}$ of October, 1974 in Durango, Mexico. In 1994 he started his studies of Civil Engineering at Instituto Tecnológico de Durango from where he graduated in May 1998. After graduation, he worked for a private construction company developing residential suburbs. In October 1999, he joined the MSc program at UNESCO-IHE in Delft, The Netherlands where he obtained his MSc degree on Environmental Science and Technology in April 2001. His research focused on a technical, organisational and financial comparison of municipal solid waste management systems between municipalities of The Netherlands (Apeldoorn) and Mexico (Durango). After his MSc graduation he returned to Durango, Mexico where he founded his own construction company. He continued developing residential suburbs and carried out diverse contracts for government agencies and private clients. In January 2003, the author enrolled at the PhD program at UNESCO-IHE with the topic: "Enhanced stabilisation of municipal solid waste in bioreactor landfills". His research work focused on the interaction and modification of the factors controlling the waste stabilisation process in a bioreactor landfill. One of the most interesting findings was the presence of Anammox bacteria -shown for the first time to be active in a bioreactor landfill- which could have contributed substantially to the removal of nitrogen and therefore bringing final disposal sites a step closer to achieve sustainability.

The results of his research have been presented at national and international symposia and conferences. In addition, several articles have been submitted for publication in peer-review journals (Waste Management, Journal of Environmental Management, Bioresource Technology and Environmental Science and Technology). His research was funded by CONACyT (Mexico), ESSENT Milieu (NL) and GeoDelft (NL). 